\title{
Synthesis of the Oxygenated Pactamycin Core
}

Spencer Knapp* and Younong Yu

Department of Chemistry \& Chemical Biology, Rutgers - The State University of New Jersey, 610 Taylor Road, Piscataway, New Jersey 08854

\section{Supporting Information}

Page

S-1 to S-24 Experimental procedures for the synthesis of 4, 5, 6, 7, 8, 9, $10,11,12,13,14,15,16,17,21,22,2,24,25,26$, and 27.

S-25 to S-55 Copies of ${ }^{1} \mathrm{H}$ and ${ }^{13} \mathrm{C}$ NMR spectra of 4 , Mosher ester of 4 $\left({ }^{1} \mathrm{H}\right.$ and $\left.{ }^{19} \mathrm{~F}\right), \mathbf{5}, \mathbf{6}, \mathbf{7}, \mathbf{8}, \mathbf{9}, \mathbf{1 0}, \mathbf{1 1}, 12$ (each isomer), 13, 14, 15 (each isomer), 16, 17, 21, 22, 2, 24, 25 (each isomer), 26 (each isomer), and 27 (each isomer).

S-56 ORTEP view of 12 (two molecules in unit cell)

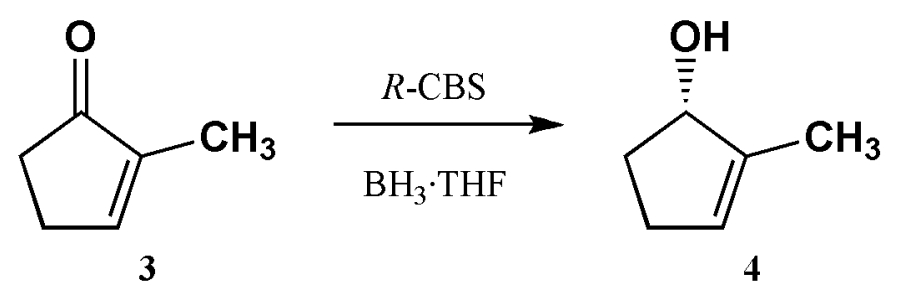

Compound 4. A solution of (R)-2-methyl-CBS-oxazaborolidine (1.0 $\mathrm{M}$ in toluene, $20.0 \mathrm{~mL}, 20.0 \mathrm{mmol})$ and $1.0 \mathrm{M}$ borane-THF in THF $(20.0 \mathrm{~mL}, 20.0 \mathrm{mmol})$ in $40.0 \mathrm{~mL}$ of additional dry THF was stirred at $0{ }^{\circ} \mathrm{C}$. Solutions of $3(9.61 \mathrm{~g}, 100 \mathrm{mmol})$ in $80.0 \mathrm{~mL}$ of dry $\mathrm{THF}$, and $50.0 \mathrm{~mL}(50.0 \mathrm{mmol})$ of $1.0 \mathrm{M} \mathrm{BH}_{3} \cdot \mathrm{THF}$ in $30.0 \mathrm{~mL}$ of dry 
THF, were added simultaneously over a 30 min period. The reaction mixture was allowed to warm slowly to room temperature, and then was quenched carefully by addition of 60 $\mathrm{mL}$ of water. The mixture was stirred for $2 \mathrm{~h}$, and then extracted with ether $(3 \times 80 \mathrm{~mL})$. The combined organic extract was washed sequentially with saturated ammonium chloride $(80 \mathrm{~mL})$ and brine $(80 \mathrm{~mL})$, dried with anhydrous magnesium sulfate, and then concentrated. The crude product was purified by flash chromatography on silica, eluting with $14 \%$ ethyl acetate in hexanes $\left(R_{f}=0.25\right)$, to give $5.3 \mathrm{~g}(54 \%)$ of 4 as a colorless oil, the NMR spectra of which match the literature values. ${ }^{1} \mathrm{H} \mathrm{NMR}\left(\mathrm{CDCl}_{3}, 400 \mathrm{MHz}\right)$ $\delta 5.53(\mathrm{~s}, 1 \mathrm{H}), 4.58$ (br s, $1 \mathrm{H}), 2.43-2.27$ (m, $2 \mathrm{H}), 2.23-2.15(\mathrm{~m}, 1 \mathrm{H}), 1.78(\mathrm{~s}, 3 \mathrm{H})$, 1.73 - 1.66 (m, $1 \mathrm{H}), 1.43$ (br s, OH); ${ }^{13} \mathrm{C} \mathrm{NMR}\left(\mathrm{CDCl}_{3}, 400 \mathrm{MHz}\right) \delta 141.6,128.1,80.0$, 34.2, 29.9, 13.8. The crude Mosher ester derivative of 4 was analyzed by ${ }^{1} \mathrm{H}$ and ${ }^{19} \mathrm{~F}$ NMR spectroscopy, and ee values of $>90 \%$ were obtained by integration of the methoxy and trifluoromethyl signals, respectively. Copies of the ${ }^{1} \mathrm{H}$ and ${ }^{19} \mathrm{~F} N \mathrm{NR}\left(\mathrm{CF}_{3}\right.$ region expanded) spectra are attached below.

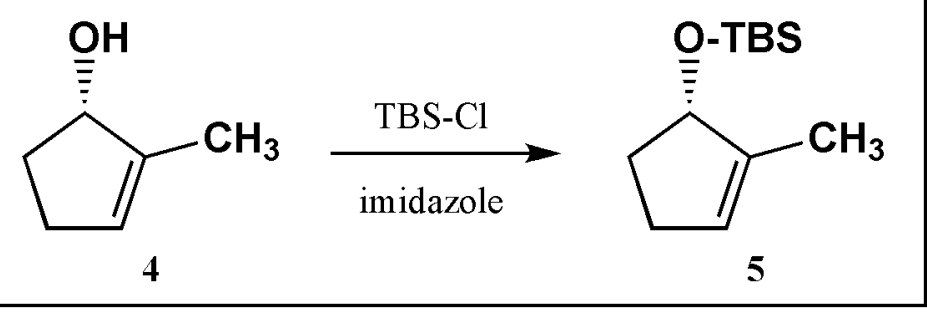

Compound 5. A solution of $4(1.96 \mathrm{~g}, 20.0 \mathrm{mmol})$ in $60 \mathrm{~mL}$ of dry dichloromethane was stirred at $0{ }^{\circ} \mathrm{C}$ under a nitrogen atmosphere. To this solution was added tert-butyldimethylsilyl chloride (3.62 g, $24 \mathrm{mmol}, 1.2$ equiv) and imidazole (2.72 g, $40 \mathrm{mmol}, 2.0$ equiv). The turbid reaction mixture was allowed to stir overnight at room temperature. Water $(30 \mathrm{~mL})$ was added, and the organic layer was reserved. The aqueous layer was further extracted with dichloromethane $(2 \times 30 \mathrm{~mL})$. The combined organic layer was washed with brine $(30 \mathrm{~mL})$, dried with anhydrous sodium sulfate, and then concentrated. The crude product was purified by flash chromatography on silica, eluting with hexanes $\left(R_{f}=0.35\right)$, to afford $5\left(4.25 \mathrm{~g}\right.$, quantitative yield) as a colorless oil. ${ }^{1} \mathrm{H}$ NMR $\left(\mathrm{CDCl}_{3}, 400 \mathrm{MHz}\right) \delta 5.46(\mathrm{~s}, 1 \mathrm{H}), 4.65$ (br s, $\left.1 \mathrm{H}\right), 2.40-2.12$ (m, $\left.3 \mathrm{H}\right), 1.71$ (s, 3 
H), 1.70 - 1.63 (m, $1 \mathrm{H}), 0.92$ (s, $9 \mathrm{H}), 0.10$ (s, $3 \mathrm{H}), 0.09$ (s, $3 \mathrm{H}) ;{ }^{13} \mathrm{C} \mathrm{NMR}\left(\mathrm{CDCl}_{3}, 400\right.$ MHz) $\delta 141.9,126.7,80.1,34.4,29.8,26.1,18.5,14.0,-4.2,-4.5$; ESI-MS $m / z 213 \mathrm{MH}^{+}$.

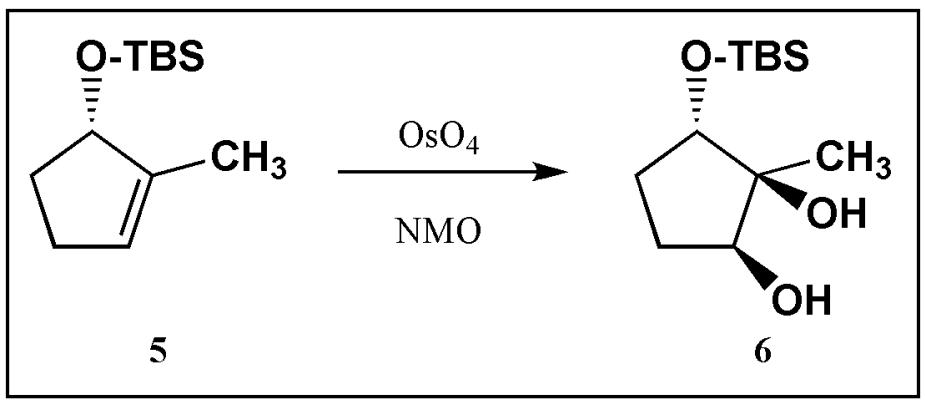

Compound 6. A solution of $5(3.0 \mathrm{~g}, 14.1 \mathrm{mmol})$ in a mixture of acetone and water $(32 \mathrm{~mL} / 2 \mathrm{~mL})$ was stirred at $0{ }^{\circ} \mathrm{C}$. 4-Methylmorpholine N-oxide (NMO, $3.3 \mathrm{~g}$, $28.2 \mathrm{mmol}, 2.0$ equiv) was added, followed by an aqueous solution of osmium tetraoxide (4\% wt in water, $d=1.04,6 \mathrm{~mL}, 0.98 \mathrm{mmol}, 0.07$ equiv). The reaction mixture was allowed to warm slowly to room temperature, and then was stirred at room temperature for another $6 \mathrm{~h}$. Sodium sulfite $(5 \mathrm{~g})$ was added, and the reaction mixture was stirred for 1 h. The mixture was concentrated to approximately half volume, and the residue was partitioned between dichloromethane $(30 \mathrm{~mL})$ and water $(15 \mathrm{~mL})$. The organic layer was reserved, and the aqueous layer was extracted with dichloromethane $(3 \times 25 \mathrm{~mL})$. The combined organic layer was washed with brine $(30 \mathrm{~mL})$, dried with anhydrous sodium sulfate, and then concentrated. The crude product was purified by flash chromatography on silica, eluting with $20 \%$ ethyl acetate in hexanes $\left(R_{f}=0.25\right)$, to afford $\mathbf{6}$ as a colorless oil (3.23 g, 93\% yield). ${ }^{1} \mathrm{H}$ NMR $\left(\mathrm{CDCl}_{3}, 400 \mathrm{MHz}\right) \delta 3.98$ (dd, $\left.J=5.0,6.6 \mathrm{~Hz}, 1 \mathrm{H}\right)$, $3.88-3.84(\mathrm{~m}, 1 \mathrm{H}), 2.16-2.03(\mathrm{~m}, 4 \mathrm{H}$, including $2 \mathrm{OH}), 1.59-1.52(\mathrm{~m}, 1 \mathrm{H}), 1.43-$ 1.36 (m, $1 \mathrm{H}), 1.19$ (s, $3 \mathrm{H}), 0.89$ (s, $9 \mathrm{H}), 0.06$ (s, $3 \mathrm{H}), 0.05$ (s, $3 \mathrm{H}) ;{ }^{13} \mathrm{C} \mathrm{NMR}\left(\mathrm{CDCl}_{3}\right.$, $400 \mathrm{MHz}) \delta 80.3,78.6,76.7,30.0,28.9,25.9,20.3,18.2,-4.4,-4.7$; ESI-MS $m / z 229 \mathrm{M}-$ $\mathrm{OH}$. 


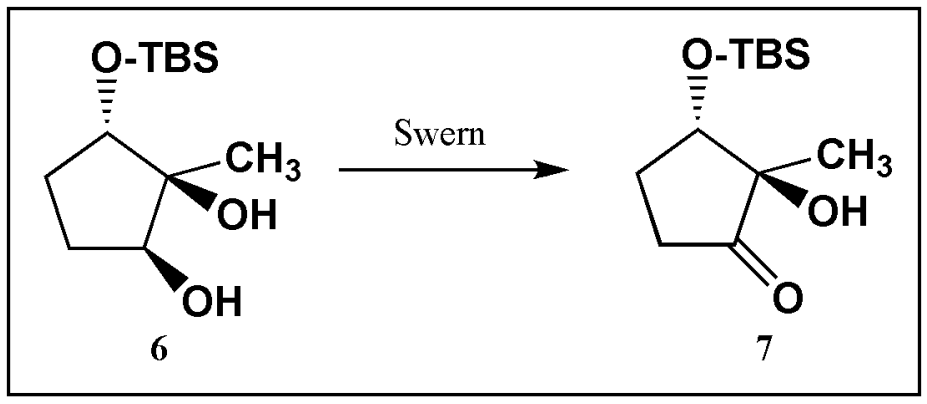

Compound 7. A solution of $1.05 \mathrm{~mL}$ (12 mmol, 1.2 equiv) of oxalyl chloride in $25 \mathrm{~mL}$ of dichloromethane was stirred at $-78^{\circ} \mathrm{C}$. A solution of $1.73 \mathrm{~mL}(24 \mathrm{mmol}, 2.4$ equiv) of DMSO in $10 \mathrm{~mL}$ of dichloromethane was added, keeping the temperature below $-65{ }^{\circ} \mathrm{C}$. After $10 \mathrm{~min}$, a solution of $6(2.46 \mathrm{~g}, 10 \mathrm{mmol})$ in $20 \mathrm{~mL}$ of dichloromethane was added slowly, again keeping the temperature below $-65{ }^{\circ} \mathrm{C}$. After $30 \mathrm{~min}$, a solution of $7 \mathrm{~mL}(50 \mathrm{mmol}, 5.0$ equiv $)$ of triethylamine in $20 \mathrm{~mL}$ of dichloromethane was added dropwise, and the resulting mixture was stirred at $-78{ }^{\circ} \mathrm{C}$ for $30 \mathrm{~min}$, and then allowed to stir at room temperature overnight. The resulting yellow reaction mixture was added to $50 \mathrm{~mL}$ of water, the organic layer was reserved, and the aqueous layer was further extracted with dichloromethane $(3 \times 30 \mathrm{~mL})$. The combined organic layer was washed with brine $(30 \mathrm{~mL})$, dried with anhydrous sodium sulfate, and then concentrated. The crude product was purified by flash chromatography on silica, eluting with $10 \%$ ethyl acetate in hexanes $\left(R_{f}=0.25\right)$, to provide $2.08 \mathrm{~g}(85 \%$ yield $)$ of 7 as a white solid, mp $51-53{ }^{\circ} \mathrm{C} .{ }^{1} \mathrm{H} \mathrm{NMR}\left(\mathrm{CDCl}_{3}, 400 \mathrm{MHz}\right) \delta 4.10(\mathrm{dd}, J=6.4,7.6 \mathrm{~Hz}$, $1 \mathrm{H}), 2.53-2.45(\mathrm{~m}, 1 \mathrm{H}), 2.38(\mathrm{~s}, 1 \mathrm{OH}), 2.29-2.12(\mathrm{~m}, 2 \mathrm{H}), 1.80-1.70(\mathrm{~m}, 1 \mathrm{H})$, 1.18 (s, $3 \mathrm{H}), 0.91(\mathrm{~s}, 9 \mathrm{H}), 0.11(\mathrm{~s}, 3 \mathrm{H}), 0.10(\mathrm{~s}, 3 \mathrm{H}) ;{ }^{13} \mathrm{C} \mathrm{NMR}\left(\mathrm{CDCl}_{3}, 400 \mathrm{MHz}\right)$ $\delta 217.8,79.8,76.7,32.8,27.2,25.9,18.2,17.6,-4.5,-4.6$; ESI-MS $m / z 267 \mathrm{MNa}^{+}$.

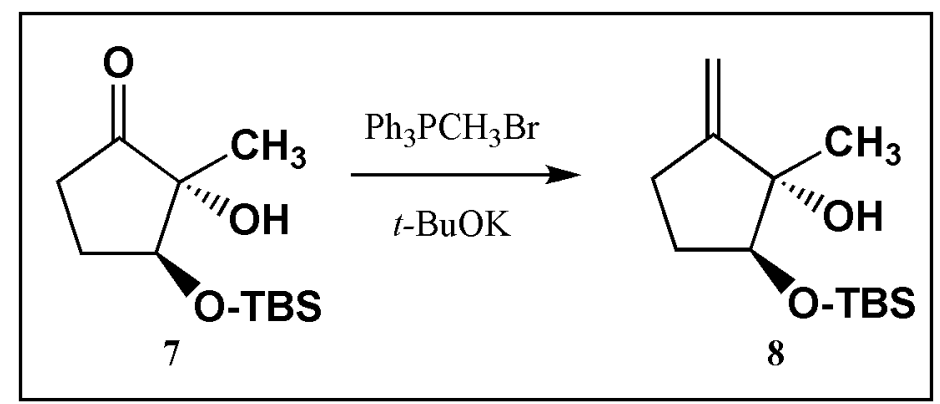


Compound 8. A suspension of dry methyltriphenylphosphonium bromide ( $4.3 \mathrm{~g}$, $12.0 \mathrm{mmol}, 2.6$ equiv) in $20 \mathrm{~mL}$ of dry THF was treated at room temperature with 11.1 $\mathrm{mL}$ (11.1 mmol, 2.4 equiv) of a $1.0 \mathrm{M}$ potassium tert-butoxide solution in THF, added dropwise. After $30 \mathrm{~min}$, the reaction mixture was cooled to $0^{\circ} \mathrm{C}$, and a solution of $1.12 \mathrm{~g}$ (4.6 mmol) of 7 in $15 \mathrm{~mL}$ of dry THF was added dropwise. The reaction mixture was stirred at room temperature for $1 \mathrm{~h}$, and then quenched with $15 \mathrm{~mL}$ of aqueous ammonium chloride. Following extraction with ether $(3 \times 30 \mathrm{~mL})$, the combined organic layer was washed with brine $(15 \mathrm{~mL})$, dried with anhydrous magnesium sulfate, and then concentrated. The crude product was purified by flash chromatography on silica, eluting with $5 \%$ ethyl acetate in hexanes $\left(R_{f}=0.3\right)$, to afford 8 as a colorless oil $(0.91 \mathrm{~g}, 82 \%$ yield). ${ }^{1} \mathrm{H}$ NMR $\left(\mathrm{CDCl}_{3}, 400 \mathrm{MHz}\right) \delta 5.13(\mathrm{t}, J=2.6 \mathrm{~Hz}, 1 \mathrm{H}), 4.93(\mathrm{t}, J=2.2 \mathrm{~Hz}, 1 \mathrm{H})$, $3.88(\mathrm{dd}, J=6.6,6.6 \mathrm{~Hz}, 1 \mathrm{H}), 2.51-2.32$ (m, $2 \mathrm{H}), 1.97-1.89$ (m, $1 \mathrm{H}), 1.57$ - 1.49 $(\mathrm{m}, 1 \mathrm{H}), 1.47(\mathrm{~s}, 1 \mathrm{OH}), 1.24(\mathrm{~s}, 3 \mathrm{H}), 0.89(\mathrm{~s}, 9 \mathrm{H}), 0.08(\mathrm{~s}, 3 \mathrm{H}), 0.07(\mathrm{~s}, 3 \mathrm{H}) ;{ }^{13} \mathrm{C}$ NMR $\left(\mathrm{CDCl}_{3}, 400 \mathrm{MHz}\right) \delta 155.5,106.9,80.6,80.5,30.0,26.8,26.0,21.8,18.2,-4.4$, 4.5; ESI-MS $m / z 265 \mathrm{MNa}^{+}$.

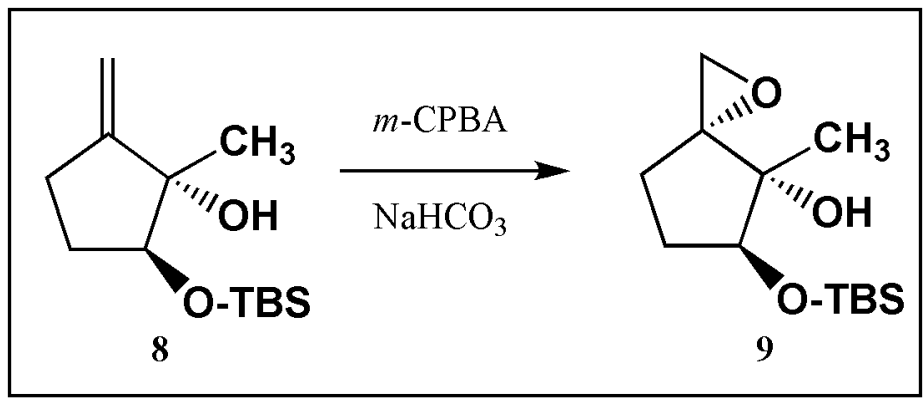

Compound 9. A solution of $8(0.8 \mathrm{~g}, 3.3 \mathrm{mmol})$ in $30 \mathrm{~mL}$ of dichloromethane was stirred at $0{ }^{\circ} \mathrm{C}$. Sodium bicarbonate $(555 \mathrm{mg}, 6.6 \mathrm{mmol}, 2.0$ equiv) was added, followed by a solution of $1.12 \mathrm{~g}$ of $m$-chloroperoxybenzoic acid ( $m$-CPBA, 77\%, 5.0 mmol, 1.5 equiv) in $15 \mathrm{~mL}$ of dichloromethane (pre-dried with anhydrous sodium sulfate). The reaction mixture was allowed to stir at room temperature overnight. A solution of $500 \mathrm{mg}$ of sodium sulfite in $10 \mathrm{~mL}$ of water was added, and the mixture was stirred for $15 \mathrm{~min}$. The organic layer was reserved, and the aqueous layer was extracted with dichloromethane $(3 \times 15 \mathrm{~mL})$. The combined organic layer was washed with brine $(15 \mathrm{~mL})$, dried with anhydrous sodium sulfate, and then concentrated. The product was 
purified by flash chromatography on silica, eluting with 5\% ethyl acetate in hexanes $\left(R_{f}=\right.$ 0.2 ), to afford $0.85 \mathrm{~g}$ (quantitative yield) of 9 as a colorless oil. ${ }^{1} \mathrm{H}$ NMR $\left(\mathrm{CDCl}_{3}, 400\right.$ MHz) $\delta 3.98$ (t, $J=7.4 \mathrm{~Hz}, 1 \mathrm{H}), 2.84$ (d, $J=8 \mathrm{~Hz}, 1 \mathrm{H}), 2.83$ (d, $J=8 \mathrm{~Hz}, 1 \mathrm{H}), 2.28-$ $2.20(\mathrm{~m}, 1 \mathrm{H}), 2.12-2.03(\mathrm{~m}, 2 \mathrm{H}$, including $1 \mathrm{OH}), 1.70-1.62(\mathrm{~m}, 1 \mathrm{H}), 1.56-1.46$ (m, $1 \mathrm{H}), 1.12$ (s, $3 \mathrm{H}), 0.90$ (s, $9 \mathrm{H}), 0.10(\mathrm{~s}, 3 \mathrm{H}), 0.08$ (s, $3 \mathrm{H}) ;{ }^{13} \mathrm{C} \mathrm{NMR}\left(\mathrm{CDCl}_{3}, 400\right.$ MHz) $\delta 79.7,76.5,66.6,49.6,28.5,26.0,25.8,18.3,17.9,-4.5,-4.6$; ESI-MS $m / z 281$ $\mathrm{MNa}^{+}$.

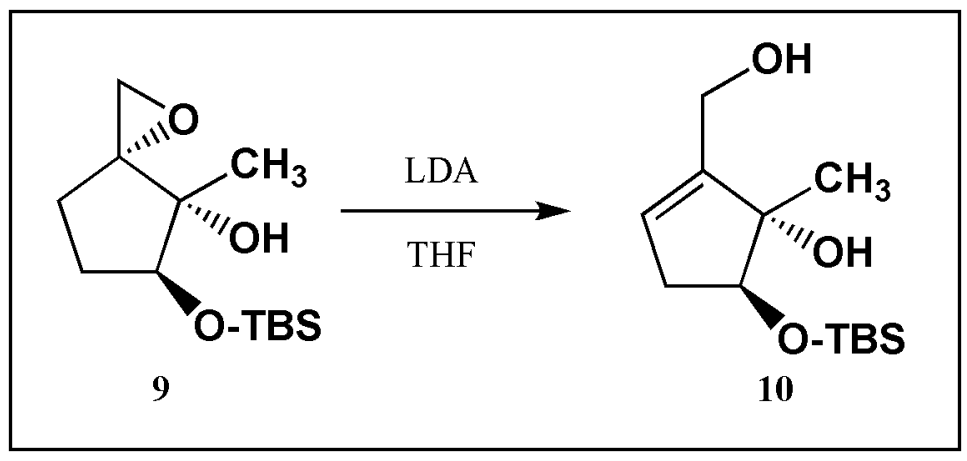

Compound 10. A solution of $1.64 \mathrm{~mL}$ of diisopropylamine $(11.6 \mathrm{mmol}, 6.0$ equiv) in $10 \mathrm{~mL}$ of dry THF was stirred at $0{ }^{\circ} \mathrm{C}$ under a nitrogen atmosphere. A solution of $3.86 \mathrm{~mL}$ ( $9.65 \mathrm{mmol}, 5.0$ equiv) of $2.5 \mathrm{M} n$-butyllithium in hexanes was dropwise. After $20 \mathrm{~min}$, a solution of $0.5 \mathrm{~g}(1.93 \mathrm{mmol})$ of 9 in $10 \mathrm{~mL}$ of dry THF was added slowly, while keeping the temperature at $0{ }^{\circ} \mathrm{C}$. The reaction mixture was allowed to stir at room temperature overnight, then was poured onto ice (15 g) and extracted with ethyl acetate $(3 \times 20 \mathrm{~mL})$. The combined organic layer was washed with brine $(20 \mathrm{~mL})$, dried with anhydrous sodium sulfate, and then concentrated. The crude product was purified by flash chromatography on silica, eluting with $33 \%$ ethyl acetate in hexanes $\left(R_{f}=0.2\right)$, to provide 10 as a white solid $(0.4 \mathrm{~g}, 80 \%$ yield $), \mathrm{mp} 68-70{ }^{\circ} \mathrm{C} .{ }^{1} \mathrm{H}$ NMR $\left(\mathrm{CDCl}_{3}, 400\right.$ MHz) $\delta 5.59$ (s, $1 \mathrm{H}), 4.33$ (d, $J=12.4 \mathrm{~Hz}, 1 \mathrm{H}), 4.22-4.17$ (m, $2 \mathrm{H}), 2.57-2.51$ (m, 1 $\mathrm{H}), 2.21(\mathrm{br} \mathrm{s}, 1 \mathrm{OH}), 2.06-2.01(\mathrm{~m}, 2 \mathrm{H}$, including $1 \mathrm{OH}), 1.26(\mathrm{~s}, 3 \mathrm{H}), 0.91(\mathrm{~s}, 9 \mathrm{H})$, 0.10 (s, $3 \mathrm{H}), 0.08$ (s, $3 \mathrm{H}) ;{ }^{13} \mathrm{C} \mathrm{NMR}\left(\mathrm{CDCl}_{3}, 400 \mathrm{MHz}\right) \delta$ 145.6, 124.6, 85.1, 82.6, 60.2, 37.9, 26.0, 20.0, 18.3, -4.4, -4.5; ESI-MS $m / z 281 \mathrm{MNa}^{+}$. 


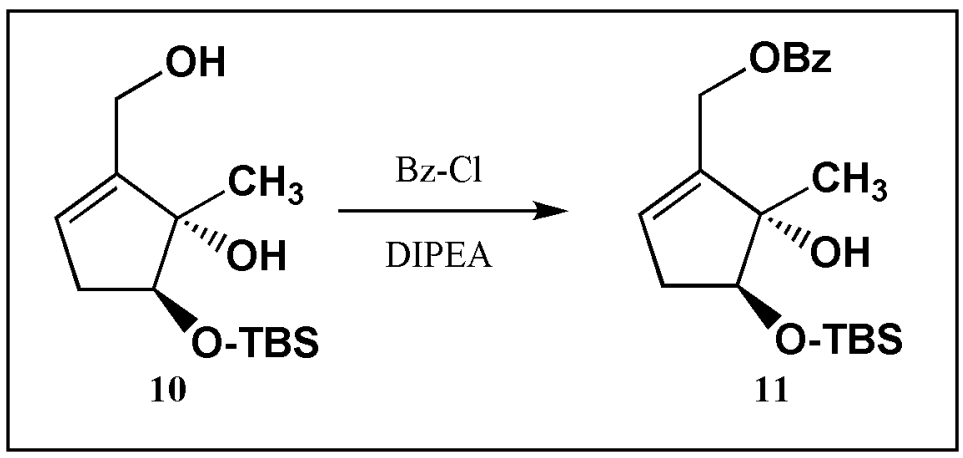

Compound 11. A solution of $0.78 \mathrm{~g}(3.0 \mathrm{mmol})$ of 10 in $30 \mathrm{~mL}$ of dry dichloromethane was stirred at $0{ }^{\circ} \mathrm{C}$ under a nitrogen atmosphere. Benzoyl chloride $(0.38$ $\mathrm{mL}, 3.3 \mathrm{mmol}, 1.1$ equiv) was added, followed by $1.05 \mathrm{~mL}$ (6.0 mmol, 2.0 equiv) of diisopropylethylamine. The reaction mixture was allowed to stir at room temperature overnight, was poured on ice (15 g), and then was extracted with dichloromethane $(3 \times$ $20 \mathrm{~mL})$. The combined organic layer was washed with brine $(20 \mathrm{~mL})$, dried with anhydrous sodium sulfate, and then concentrated. The crude product was purified by flash chromatography on silica, eluting with $8 \%$ ethyl acetate in hexanes $\left(R_{f}=0.3\right)$, to afford 11 as a colorless oil $(0.98 \mathrm{~g}, 90 \%$ yield $) .{ }^{1} \mathrm{H} \mathrm{NMR}\left(\mathrm{CDCl}_{3}, 400 \mathrm{MHz}\right) \delta 8.05$ (dd, $J$ $=8.0 \mathrm{~Hz}, 1.2 \mathrm{~Hz}, 2 \mathrm{H}), 7.56(\mathrm{dt}, J=8.0 \mathrm{~Hz}, 1.2 \mathrm{~Hz}, 1 \mathrm{H}), 7.43(\mathrm{t}, J=8.0 \mathrm{~Hz}, 2 \mathrm{H}), 5.75$ (dd, $J=2.8 \mathrm{~Hz}, 1.2 \mathrm{~Hz}, 1 \mathrm{H}), 4.93$ (d, $J=1.6 \mathrm{~Hz}, 2 \mathrm{H}), 4.20$ (t, $J=14.8 \mathrm{~Hz}, 1 \mathrm{H}), 2.57$ $2.51(\mathrm{~m}, 1 \mathrm{H}), 2.13-2.06(\mathrm{~m}, 2 \mathrm{H}$, including $1 \mathrm{OH}), 1.29(\mathrm{~s}, 3 \mathrm{H}), 0.92(\mathrm{~s}, 9 \mathrm{H}), 0.11(\mathrm{~s}$, $3 \mathrm{H}), 0.08(\mathrm{~s}, 3 \mathrm{H}) ;{ }^{13} \mathrm{C} \mathrm{NMR}\left(\mathrm{CDCl}_{3}, 400 \mathrm{MHz}\right) \delta 166.4,142.5,133.0,130.0,129.5$, 128.3, 127.0, 83.8, 82.5, 61.2, 37.9, 26.0, 20.2, 18.3, -4.4, -4.5; ESI-MS $m / z 385 \mathrm{MNa}^{+}$.

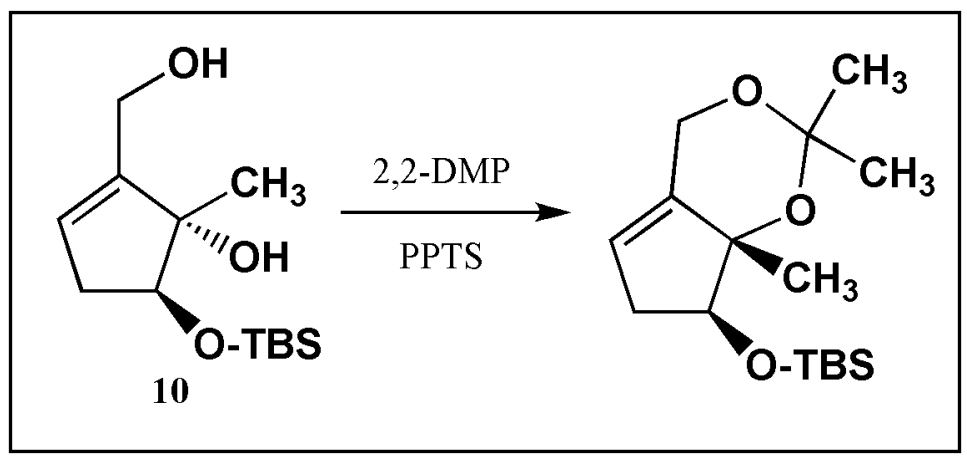

Ketalization/desilylation of 10. A mixture of $300 \mathrm{mg}(1.16 \mathrm{mmol})$ of the allylic diol 10, $10 \mathrm{~mL}$ of dry DMF, $2.85 \mathrm{~mL}$ (23.2 mmol, 20 equiv) of 2,2-dimethoxypropane, 
$146 \mathrm{mg}$ ( $0.58 \mathrm{mmol}, 0.5$ equiv) of pyridinium $p$-toluenesulfonate, and $300 \mathrm{mg}$ of $4-\AA$ molecular sieves was heated in a sealed tube at $80{ }^{\circ} \mathrm{C}$ for 2 days. The reaction mixture was cooled, and then filtered through a Celite pad, rinsing with dichloromethane $(2 \times 10$ $\mathrm{mL}$ ). The combined filtrate was concentrated, and the residue was dissolved in $30 \mathrm{~mL}$ of EtOAc. The organic solution was washed sequentially with saturated aqueous sodium bicarbonate $(2 \times 10 \mathrm{~mL})$ and brine $(10 \mathrm{~mL})$, dried with anhydrous sodium sulfate, and then concentrated. The product was purified by flash chromatography on silica, eluting with $2 \%$ ethyl acetate in hexanes $\left(R_{f}=0.25\right)$, to afford the acetonide product as a colorless oil (194 mg, 56\% yield). ${ }^{1} \mathrm{H}$ NMR $\left(\mathrm{CDCl}_{3}, 400 \mathrm{MHz}\right) \delta 5.38$ (s, $\left.1 \mathrm{H}\right), 4.61$ (dd, $J=14.6 \mathrm{~Hz}, 2.2 \mathrm{~Hz}, 1 \mathrm{H}), 4.41(\mathrm{~d}, J=14.8 \mathrm{~Hz}, 1 \mathrm{H}), 4.19$ (t, $J=8.2 \mathrm{~Hz}, 1 \mathrm{H}), 2.42-$ $2.36(\mathrm{~m}, 1 \mathrm{H}), 2.07-1.97$ (m, $1 \mathrm{H}), 1.38$ (s, $6 \mathrm{H}), 1.23$ (s, $3 \mathrm{H}), 0.90$ (s, $9 \mathrm{H}), 0.08$ (s, 3 $\mathrm{H}), 0.06(\mathrm{~s}, 3 \mathrm{H}) ;{ }^{13} \mathrm{C} \mathrm{NMR}\left(\mathrm{CDCl}_{3}, 400 \mathrm{MHz}\right) \delta 140.4,119.0,99.1,83.6,83.1,60.9$, $37.5,29.1,27.3,26.3,19.8,18.7,-4.1,-4.4$; ESI-MS $m / z 322 \mathrm{MNa}^{+}$.

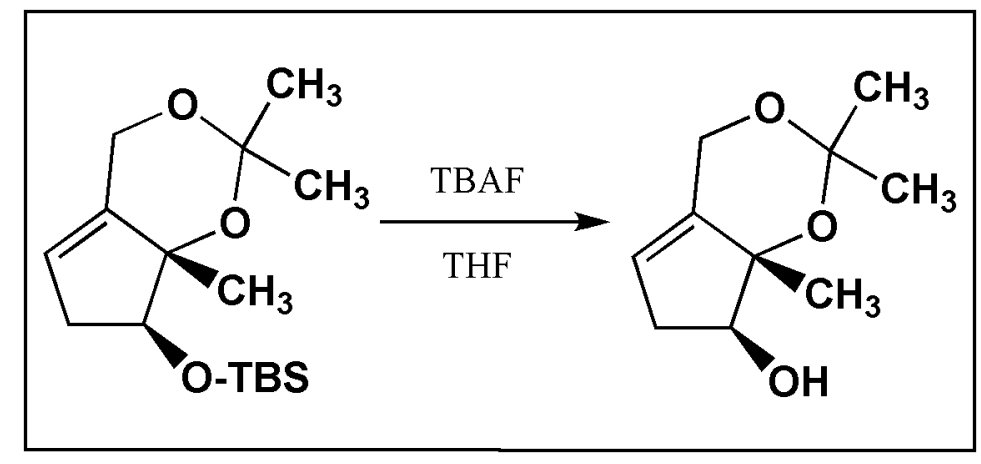

A solution of $160 \mathrm{mg}(0.54 \mathrm{mmol})$ of the acetonide in $6 \mathrm{~mL}$ of THF was treated with 1.08 $\mathrm{mL}$ (1.0 M solution in THF, $1.08 \mathrm{mmol}, 2.0$ equiv) of tetra- $n$-butylammonium fluoride (TBAF) solution, added dropwise. After $3 \mathrm{~h}$, the solvent was evaporated, and the residue was purified by column chromatography on silica, eluting with $20 \%$ ethyl acetate in hexanes $\left(R_{f}=0.3\right)$ to afford the homoallylic alcohol product as a colorless oil $(90 \mathrm{mg}$, 91\% yield). ${ }^{1} \mathrm{H}$ NMR $\left(\mathrm{CDCl}_{3}, 400 \mathrm{MHz}\right) \delta 5.40$ (s, $\left.1 \mathrm{H}\right), 4.66-4.60$ (m, $1 \mathrm{H}$ ), 4.45 (d, J $=14.0 \mathrm{~Hz}, 1 \mathrm{H}$ ), 4.25 (t, $J=8.2 \mathrm{~Hz}, 1 \mathrm{H}$ ), $3.20(\mathrm{br} \mathrm{s}, \mathrm{OH}), 2.55-2.49(\mathrm{~m}, 1 \mathrm{H}), 2.10-$ $2.05(\mathrm{~m}, 1 \mathrm{H}), 1.41(\mathrm{~s}, 3 \mathrm{H}), 1.40(\mathrm{~s}, 3 \mathrm{H}), 1.30(\mathrm{~s}, 3 \mathrm{H}) ;{ }^{13} \mathrm{C} \mathrm{NMR}\left(\mathrm{CDCl}_{3}, 400 \mathrm{MHz}\right)$ $\delta$ 139.6, 119.0, 99.5, 83.5, 82.7, 60.6, 36.0, 29.0, 26.5, 19.5; ESI-MS m/z $186 \mathrm{MH}^{+}$. 


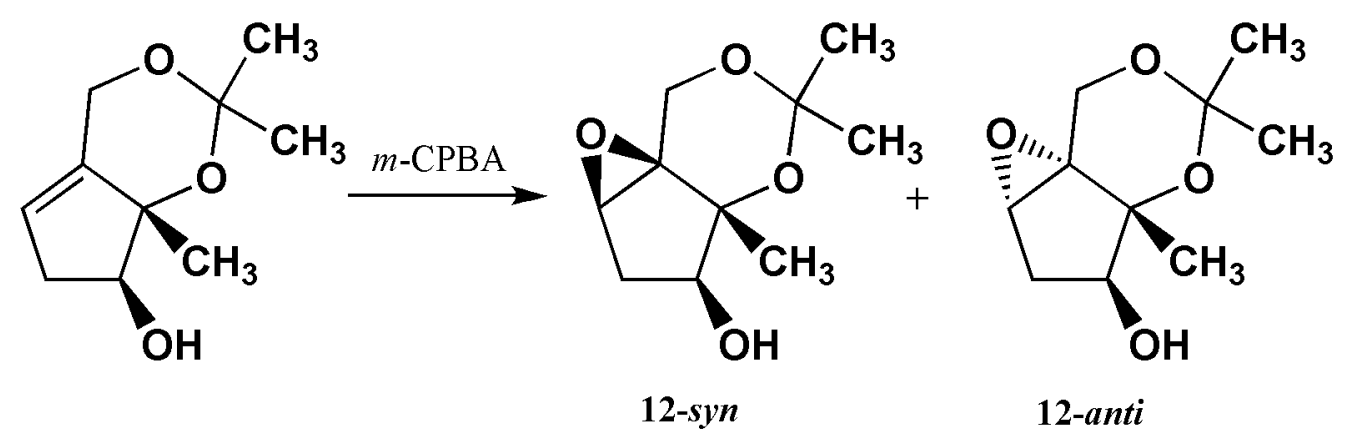

Epoxy Alcohols 12-Anti and 12-Syn. A solution of $300 \mathrm{mg}(1.63 \mathrm{mmol})$ of the homoallylic alcohol described above in $6 \mathrm{~mL}$ of dichloromethane was stirred at $0{ }^{\circ} \mathrm{C}$. A solution of $585 \mathrm{mg}(2.61 \mathrm{mmol})$ of $77 \% \mathrm{~m}$-CPBA in $10 \mathrm{~mL}$ of dichloromethane was added dropwise. The reaction mixture was stirred at room temperature for 2 days. A 10\% aqueous sodium thiosulfate solution $(10 \mathrm{~mL})$ was added, and the resulting heterogeneous mixture was vigorously stirred for $5 \mathrm{~min}$. The organic layer was reserved, and the aqueous layer was further extracted with dichloromethane $(2 \times 15 \mathrm{~mL})$. The combined organic layer was washed sequentially with saturated aqueous sodium bicarbonate (10 $\mathrm{mL})$ and brine $(10 \mathrm{~mL})$, dried with anhydrous sodium sulfate, and then concentrated. The product was purified by flash chromatography on silica, eluting with mixtures of ethyl acetate and hexanes $(20-35 \%)$. For the $1^{\text {st }}$ product (a little more polar than the starting material), elution with $20 \%$ EtOAc in hexanes $\left(R_{f}=0.28\right)$ afforded the 12-syn as a white solid (115 mg, 35\%), mp 67-69 ${ }^{\circ} \mathrm{C}$. For the $2^{\text {nd }}$ band (the more polar isomer), elution with $35 \%$ EtOAc in hexanes $\left(R_{f}=0.25\right)$ gave 12-anti as a white solid (79 $\mathrm{mg}, 24 \%$ yield), $\mathrm{mp} 59-61{ }^{\circ} \mathrm{C}$. Crystals of 12-anti suitable for $\mathrm{x}$-ray analysis were grown by slow diffusion of petroleum ether into a toluene solution. Compound 12-syn: ${ }^{1} \mathrm{H} \mathrm{NMR}\left(\mathrm{CDCl}_{3}\right.$, $400 \mathrm{MHz}) \delta 4.23(\mathrm{~d}, J=11.6 \mathrm{~Hz}, 1 \mathrm{H}), 3.92(\mathrm{~d}, J=12.0 \mathrm{~Hz}, 1 \mathrm{H}), 3.66$ (br s, $1 \mathrm{H}), 3.51$ (s, $1 \mathrm{H}), 2.39(\mathrm{dd}, J=15.4,6.6 \mathrm{~Hz}, 1 \mathrm{H}), 2.00(\mathrm{~d}, J=15.6 \mathrm{~Hz}, 1 \mathrm{H}), 1.70$ (br s, OH), 1.54 $(\mathrm{s}, 3 \mathrm{H}), 1.45$ (s, $3 \mathrm{H}), 1.39$ (s, $3 \mathrm{H}) ;{ }^{13} \mathrm{C} \mathrm{NMR}\left(\mathrm{CDCl}_{3}, 400 \mathrm{MHz}\right) \delta 100.7,80.8$, 77.6, 65.5, 65.1, 59.0, 35.9, 29.6, 26.5, 17.2; ESI-MS $m / z 223 \mathrm{MNa}^{+}, 423 \mathrm{M}_{2} \mathrm{Na}^{+}$. Compound 12-anti: ${ }^{1} \mathrm{H} \mathrm{NMR}\left(\mathrm{CDCl}_{3}, 400 \mathrm{MHz}\right) \delta 4.57(\mathrm{~d}, J=12.8 \mathrm{~Hz}, 1 \mathrm{H}), 4.00(\mathrm{~d}, J=12.4 \mathrm{~Hz}, 1$ H), $3.92(\mathrm{t}, J=7.6 \mathrm{~Hz}, 1 \mathrm{H}), 3.63(\mathrm{~s}, 1 \mathrm{H}), 2.42(\mathrm{dd}, J=14.0,7.2 \mathrm{~Hz}, 1 \mathrm{H}), 2.25-2.35$ 
(m, $1 \mathrm{H}), 1.73$ (br s, OH), 1.59 (s, $3 \mathrm{H}), 1.47(\mathrm{~s}, 3 \mathrm{H}), 1.40(\mathrm{~s}, 3 \mathrm{H}) ;{ }^{13} \mathrm{C} \mathrm{NMR}\left(\mathrm{CDCl}_{3}\right.$, $400 \mathrm{MHz}) \delta$ 100.8, 78.3, 73.8, 64.0, 62.3, 57.9, 33.8, 30.7, 25.1, 18.3.

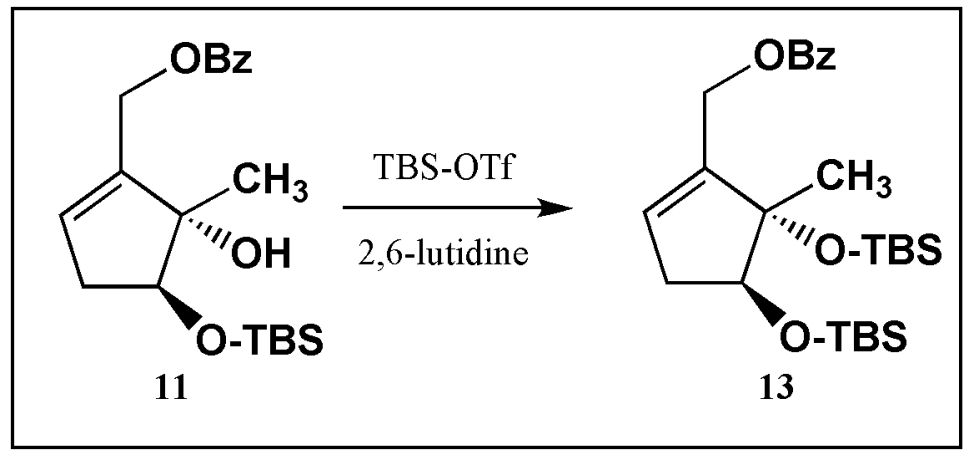

Compound 13. A solution of $0.4 \mathrm{~g}(1.1 \mathrm{mmol})$ of $\mathbf{1 1}$ in $6 \mathrm{~mL}$ of dry DMF was stirred at $0{ }^{\circ} \mathrm{C}$ under a nitrogen atmosphere. 2,6-Lutidine (1.28 mL, $11 \mathrm{mmol}, 10$ equiv) was added, followed by $1.52 \mathrm{~mL}(6.6 \mathrm{mmol}, 6$ equiv) of tert-butyldimethylsilyl trifluoromethanesulfonate. The reaction mixture was stirred for $3 \mathrm{~h}$ while the temperature was allowed to rise slowly to room temperature, and then was quenched by addition of 10 $\mathrm{mL}$ of saturated aqueous sodium bicarbonate. The mixture was extracted with EtOAc (3 $\times 15 \mathrm{~mL})$. The combined organic layer was washed sequentially with water $(3 \times 10 \mathrm{~mL})$ and brine $(10 \mathrm{~mL})$, dried with anhydrous sodium sulfate, and then concentrated. The product was purified by flash chromatography on silica, eluting with $4 \%$ ethyl acetate in hexanes $\left(R_{f}=0.3\right)$, to afford 13 as a colorless oil $(0.5 \mathrm{~g}, 95 \%$ yield $) .{ }^{1} \mathrm{H} \mathrm{NMR}\left(\mathrm{CDCl}_{3}\right.$, $400 \mathrm{MHz}) \delta 8.06$ (dd, $J=7.6 \mathrm{~Hz}, 1.6 \mathrm{~Hz}, 2 \mathrm{H}), 7.56$ (tt, $J=7.6 \mathrm{~Hz}, 1.6 \mathrm{~Hz}, 1 \mathrm{H}), 7.44$ (t, $J=7.6 \mathrm{~Hz}, 2 \mathrm{H}), 5.65$ (dd, $J=2.8 \mathrm{~Hz}, 1.2 \mathrm{~Hz}, 1 \mathrm{H}), 4.94-4.83(\mathrm{~m}, 2 \mathrm{H}), 4.24(\mathrm{t}, J=7.0$ Hz, 1 H), 2.58- 2.51 (m, 1 H), $2.09-2.02$ (m, 1 H), 1.35 (s, 3 H), 0.92 (s, 9 H), 0.87 (s, 9 $\mathrm{H}), 0.13(\mathrm{~s}, 3 \mathrm{H}), 0.12$ (s, $3 \mathrm{H}), 0.10$ (s, $3 \mathrm{H}), 0.08(\mathrm{~s}, 3 \mathrm{H}) ;{ }^{13} \mathrm{C}$ NMR $\left(\mathrm{CDCl}_{3}, 400 \mathrm{MHz}\right)$

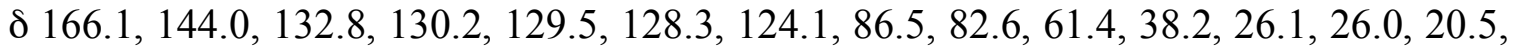
$18.3,18.2,-1.8,-1.9,-3.5,-4.4$; ESI-MS $m / z 499 \mathrm{MNa}^{+}$. 


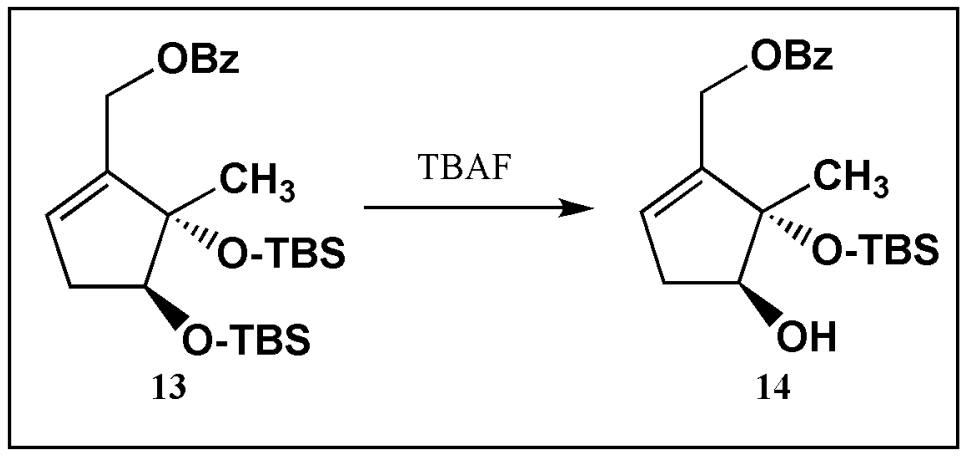

Compound 14. A solution of $13(280 \mathrm{mg}, 0.59 \mathrm{mmol})$ in $6 \mathrm{~mL}$ of dry THF was stirred at $0{ }^{\circ} \mathrm{C}$. TBAF $(0.71 \mathrm{~mL}$ of a $1.0 \mathrm{M}$ solution in THF, 1.2 equiv) was added dropwise. The reaction mixture was allowed to stir at room temperature overnight. After concentration, the residue was partitioned between $20 \mathrm{~mL}$ of ethyl acetate and $10 \mathrm{~mL}$ of water. The organic layer was reserved, and the aqueous layer was further extracted with EtOAc $(3 \times 10 \mathrm{~mL})$. The combined organic layer was washed with brine $(10 \mathrm{~mL})$, dried with anhydrous sodium sulfate, and then concentrated. The crude product was purified by flash chromatography on silica, eluting with $12 \%$ ethyl acetate in hexanes $\left(R_{f}=0.25\right)$, to afford 14 as a colorless oil (0.2 g, 92\% yield). ${ }^{1} \mathrm{H} \mathrm{NMR}\left(\mathrm{CDCl}_{3}, 400 \mathrm{MHz}\right) \delta 8.06$ (dd, $J$ $=7.6 \mathrm{~Hz}, 1.6 \mathrm{~Hz}, 2 \mathrm{H}), 7.56$ (tt, $J=7.6 \mathrm{~Hz}, 1.6 \mathrm{~Hz}, 1 \mathrm{H}), 7.45$ (t, $J=7.6 \mathrm{~Hz}, 2 \mathrm{H}), 5.75$ (dd, $J=3.0 \mathrm{~Hz}, 1.4 \mathrm{~Hz}, 1 \mathrm{H}), 4.93-4.85$ (m, 2 H), 4.28 (dd, $J=14.0 \mathrm{~Hz}, 7.2 \mathrm{~Hz}, 1 \mathrm{H})$, $2.69-2.63(\mathrm{~m}, 1 \mathrm{H}), 2.14-2.06(\mathrm{~m}, 1 \mathrm{H}), 1.70(\mathrm{~d}, J=6.0 \mathrm{~Hz}, 1 \mathrm{OH}), 1.36(\mathrm{~s}, 3 \mathrm{H}), 0.88$ (s, $9 \mathrm{H}), 0.15$ (s, $3 \mathrm{H}), 0.14$ (s, $3 \mathrm{H}) ;{ }^{13} \mathrm{C} \mathrm{NMR}\left(\mathrm{CDCl}_{3}, 400 \mathrm{MHz}\right) \delta 166.1,144.3,132.9$, $130.1,129.5,128.3,123.8,85.5,82.1,61.1,37.5,25.9,20.3,18.3,-2.1,-2.3$; ESI-MS $m / z$ $385 \mathrm{MNa}^{+}$.

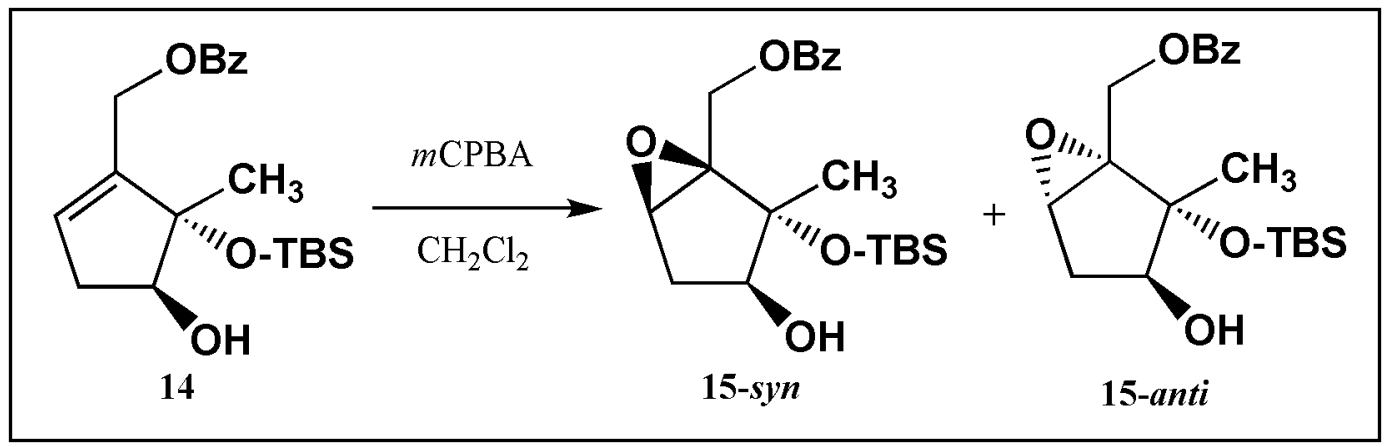

Epoxy Alcohols 15-Syn and 15-Anti. A solution of $140 \mathrm{mg}(0.39 \mathrm{mmol})$ of 14 in $4 \mathrm{~mL}$ of dry dichloromethane was stirred at $-20^{\circ} \mathrm{C}$. One $\mathrm{mL}(0.51 \mathrm{mmol}, 1.3$ equiv $)$ of an 
$m$-CPBA solution in dichloromethane $(457 \mathrm{mg}$ of $77 \% \mathrm{~m}$-CPBA, $2.04 \mathrm{mmol}$, in $4 \mathrm{~mL}$ of dry dichloromethane) was added dropwise. The reaction mixture was allowed to stir at $20{ }^{\circ} \mathrm{C}$ until all the starting material was consumed, about 2.5 days. The reaction mixture was quenched with $3 \mathrm{~mL}$ of $10 \%$ aqueous sodium thiosulfate. The organic layer was reserved, and the aqueous layer was further extracted with dichloromethane $(2 \times 5 \mathrm{~mL})$. The combined organic layer was washed sequentially with saturated aqueous sodium bicarbonate solution $(5 \mathrm{~mL})$ and brine $(5 \mathrm{~mL})$, dried with anhydrous sodium sulfate, and then concentrated. The crude product was purified by flash chromatography on silica, eluting with mixtures of ethyl acetate and hexanes. For the major product 15-syn (the less polar of the two isomeric products, but a little more polar than the starting material), $10 \%$ ethyl acetate in hexanes was used to elute product $\left(R_{f}=0.20\right)$ as a colorless oil $(109 \mathrm{mg}$, $74 \%$ ). For the minor isomer 15-anti (more polar isomer), 16\% ethyl acetate in hexanes was used $\left(R_{f}=0.20,12 \mathrm{mg}, 8 \%\right.$ yield $)$. The major isomer 15-syn: ${ }^{1} \mathrm{H}$ NMR $\left(\mathrm{CDCl}_{3}, 400\right.$ MHz) $\delta 8.04$ (dd, $J=7.8 \mathrm{~Hz}, 1.2 \mathrm{~Hz}, 2 \mathrm{H}), 7.57$ (tt, $J=7.8 \mathrm{~Hz}, 1.2 \mathrm{~Hz}, 1 \mathrm{H}), 7.45$ (t, $J=$ $7.8 \mathrm{~Hz}, 2 \mathrm{H}), 4.97$ (d, $J=12.6 \mathrm{~Hz}, 1 \mathrm{H}), 4.48$ (d, $J=12.6 \mathrm{~Hz}, 1 \mathrm{H}), 3.69$ (s, $1 \mathrm{H}), 3.66$ (br, $1 \mathrm{H}), 2.31$ (dd, $J=14.6 \mathrm{~Hz}, 5.8 \mathrm{~Hz}, 1 \mathrm{H}), 2.18$ (br s, OH), 2.05 (d, $J=14.6 \mathrm{~Hz}, 1 \mathrm{H})$, 1.59 (s, $3 \mathrm{H}), 0.86$ (s, $9 \mathrm{H}), 0.14$ (s, $3 \mathrm{H}), 0.12$ (s, $3 \mathrm{H}) ;{ }^{13} \mathrm{C} \mathrm{NMR}\left(\mathrm{CDCl}_{3}, 400 \mathrm{MHz}\right)$ ठ 166.4, 133.4, 129.9 (2C), 128.7, 82.3, 78.7, 69.4, 62.0, 60.7, 35.5, 25.9, 18.8, 18.2, -2.0, -2.2; ESI-MS $m / z 379 \mathrm{MH}^{+}$. The minor isomer 15-anti: ${ }^{1} \mathrm{H} \mathrm{NMR}\left(\mathrm{CDCl}_{3}, 400 \mathrm{MHz}\right)$ $\delta 8.01(\mathrm{~d}, J=6.4 \mathrm{~Hz}, 2 \mathrm{H}), 7.56(\mathrm{t}, J=7.2 \mathrm{~Hz}, 1 \mathrm{H}), 7.43$ (t, $J=7.6 \mathrm{~Hz}, 2 \mathrm{H}), 4.82$ (d, $J=$ $13.2 \mathrm{~Hz}, 1 \mathrm{H}), 4.60$ (d, $J=12.4 \mathrm{~Hz}, 1 \mathrm{H}), 4.01$ (q, $J=6.8 \mathrm{~Hz}, 1 \mathrm{H}), 3.49$ (s, $1 \mathrm{H}), 2.47$ $(\mathrm{dd}, J=14.0 \mathrm{~Hz}, 7.2 \mathrm{~Hz}, 1 \mathrm{H}), 1.57$ (d, $J=5.6 \mathrm{~Hz}, \mathrm{OH}), 1.53(\mathrm{dd}, J=14.0 \mathrm{~Hz}, J=8.8$ $\mathrm{Hz}, 1 \mathrm{H}), 1.32$ (s, $3 \mathrm{H}), 0.89$ (s, $9 \mathrm{H}), 0.16$ (s, $3 \mathrm{H}), 0.15(\mathrm{~s}, 3 \mathrm{H}) ;{ }^{13} \mathrm{C} \mathrm{NMR}\left(\mathrm{CDCl}_{3}, 400\right.$ MHz) $\delta 166.0,133.1,129.60,129.56,128.3,81.7,75.3,66.7,60.3,57.0,33.6,25.9,18.8$, 18.3, -2.2, -2.4; ESI-MS $m / z 379 \mathrm{MH}^{+}, 401 \mathrm{MNa}^{+}$. 


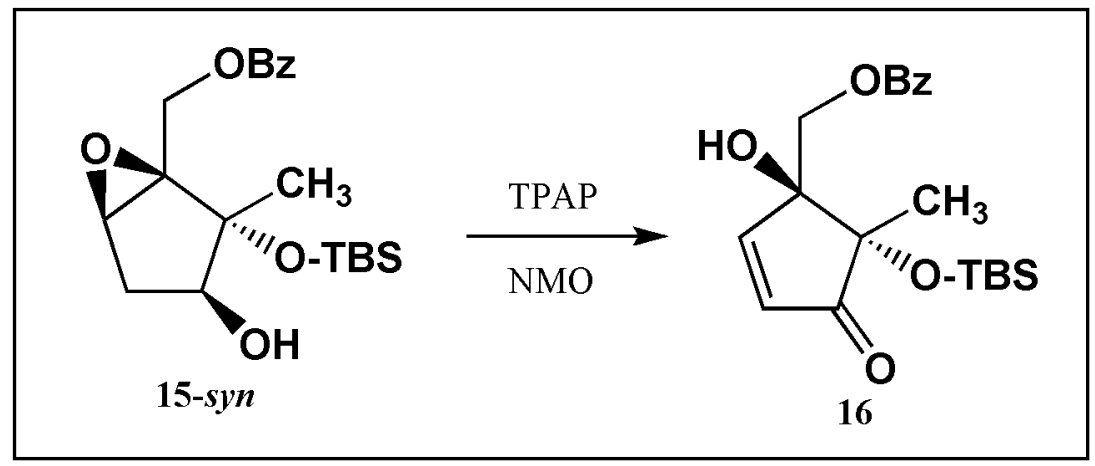

Compound 16. A solution of $250 \mathrm{mg}(0.66 \mathrm{mmol})$ of 15-syn in $15 \mathrm{~mL}$ of dichloromethane was treated with 4-methylmorpholine-N-oxide (NMO, $155 \mathrm{mg}, 1.32$ mmol, 2.0 equiv) in one portion, followed by a catalytic amount of tetra- $n$ propylammonium perruthenate (TPAP, $46 \mathrm{mg}, 0.13 \mathrm{mmol}, 0.2$ equiv). The reaction mixture was stirred at room temperature for $2 \mathrm{~h}$. During this period, the starting material was consumed and two products were formed, according to TLC analysis: one less polar than the starting material, and one more polar. Hexanes $(15 \mathrm{~mL})$ was added to the reaction mixture, and the mixture was filtered through a Celite pad, washing with $15 \mathrm{~mL}$ of 1:1 dichloromethane / hexanes. The combined filtrate was concentrated. TLC analysis indicated that the less polar spot, presumably the epoxy ketone, had disappeared. The crude product was purified by flash chromatography on silica, eluting with $16 \%$ ethyl acetate in hexanes, to afford $16\left(R_{f}=0.20\right)$ as a white solid $(216 \mathrm{mg}, 87 \%$ yield $), \mathrm{mp} 114$ - $116{ }^{\circ} \mathrm{C} .{ }^{1} \mathrm{H}$ NMR $\left(\mathrm{CDCl}_{3}, 400 \mathrm{MHz}\right) \delta 7.99$ (d, $\left.J=8.0 \mathrm{~Hz}, 2 \mathrm{H}\right), 7.58$ (t, $J=7.4 \mathrm{~Hz}, 1$ H), 7.45 (t, $J=7.8 \mathrm{~Hz}, 2 \mathrm{H}), 7.37$ (d, $J=6.8 \mathrm{~Hz}, 1 \mathrm{H}$ ), 6.29 (d, $J=5.6 \mathrm{~Hz}, 1 \mathrm{H}), 4.77$ (d, $J=11.6 \mathrm{~Hz}, 1 \mathrm{H}), 4.24$ (d, $J=12.0 \mathrm{~Hz}, 1 \mathrm{H}), 2.94$ (br s, OH), 1.40 (s, $3 \mathrm{H}), 0.88$ (s, $9 \mathrm{H})$, 0.28 (s, $3 \mathrm{H}), 0.11(\mathrm{~s}, 3 \mathrm{H}) ;{ }^{13} \mathrm{C} \mathrm{NMR}\left(\mathrm{CDCl}_{3}, 400 \mathrm{MHz}\right) \delta 206.0,167.3,160.1,133.7$, $132.4,130.0,129.6,128.8,84.1,82.4,69.6,26.1,22.7,18.7,-2.0,-2.6$; IR (neat) 3460, $1727 \mathrm{~cm}^{-1}$; ESI-MS m/z $399 \mathrm{MNa}^{+}$; FAB-HRMS calcd for $\mathrm{C}_{20} \mathrm{H}_{29} \mathrm{O}_{5} \mathrm{Si} 377.1784$, found 377.1776 . 


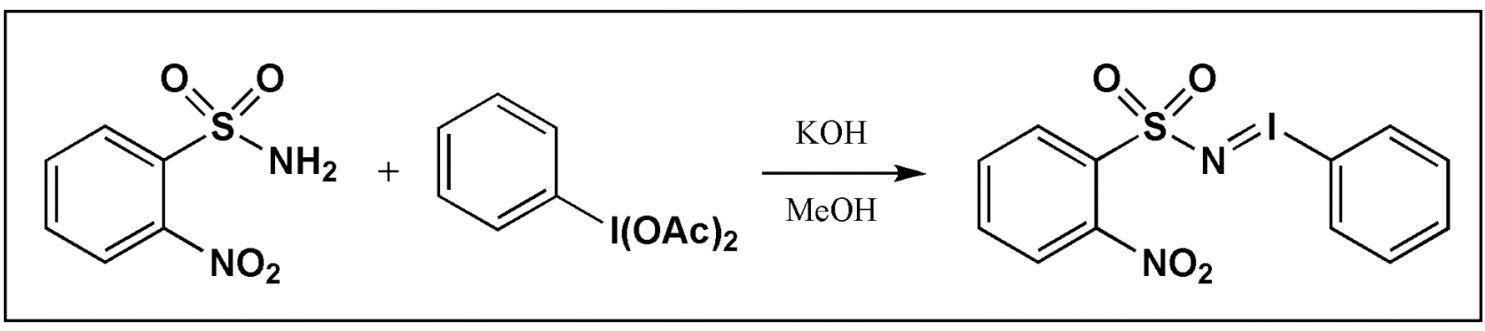

[ $N$-(2-nitrophenylsulfonyl)imino]phenyliodinane. Iodobenzene diacetate $(6.44$ g, $20.0 \mathrm{mmol})$ was added to a stirred mixture of potassium hydroxide $(2.81 \mathrm{~g}, 50.0 \mathrm{mmol}$, 2.5 equiv) and 2-nitrobenzenesulfonamide (4.04 g, $20 \mathrm{mmol}, 1.0$ equiv) in $80 \mathrm{~mL}$ of dry methanol, while keeping the temperature at $0{ }^{\circ} \mathrm{C}$. The reaction mixture was allowed to stir overnight. The supernatant was filtered, washed with distilled water, and then dried at room temperature in a vacuum desiccator for 2 days to afford $5.09 \mathrm{~g}(63 \%$ yield) of the product as a white powder, mp $130-132{ }^{\circ} \mathrm{C} .{ }^{1} \mathrm{H}$ NMR (DMSO- $\left.d_{6}, 400 \mathrm{MHz}\right) \delta 7.76(\mathrm{~d}, J$ $=8.4 \mathrm{~Hz}, 2 \mathrm{H}), 7.65(\mathrm{~d}, J=8.0 \mathrm{~Hz}, 1 \mathrm{H}), 7.57(\mathrm{~d}, J=8.0 \mathrm{~Hz}, 1 \mathrm{H}), 7.49$ (t, $J=7.6 \mathrm{~Hz}, 1$ $\mathrm{H}), 7.44-7.36(\mathrm{~m}, 2 \mathrm{H}), 7.27(\mathrm{t}, J=7.6 \mathrm{~Hz}, 2 \mathrm{H}) ;{ }^{13} \mathrm{C}$ NMR (DMSO-d $d_{6}, 400 \mathrm{MHz}$ ) $\delta 147.5,137.1,133.9,131.9,131.4,131.2,130.7,129.7,123.3,117.5$; ESI-MS: 405 $\mathrm{MH}^{+}$.

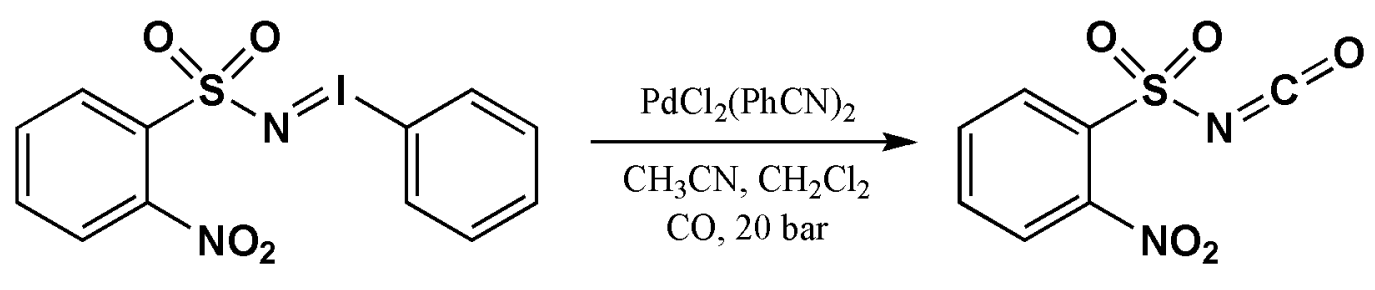

2-Nitrobenzenesulfonylisocyanate Stock Solution. A $45 \mathrm{~mL}$ stainless steel Parr reactor was charged with $5.4 \mathrm{~g} \quad(13.4 \mathrm{mmol})$ of $[N-(2-$ nitrophenylsulfonyl)imino]phenyliodinane, $134 \mathrm{mg}(0.35 \mathrm{mmol}, 0.025$ equiv $)$ of bis(benzonitrile)palladium (II) chloride, $20 \mathrm{~mL}$ of dry dichloromethane, and $0.2 \mathrm{~mL}$ of dry acetonitrile. The reactor was pressurized to 20 bar with carbon monoxide and stirred for 2.5 days at room temperature. The tea-brown-colored liquid was transferred to a 50 $\mathrm{mL}$ flask for use as a stock solution of (moisture sensitive) 2-nitrobenzenesulfonyl isocyanate. 


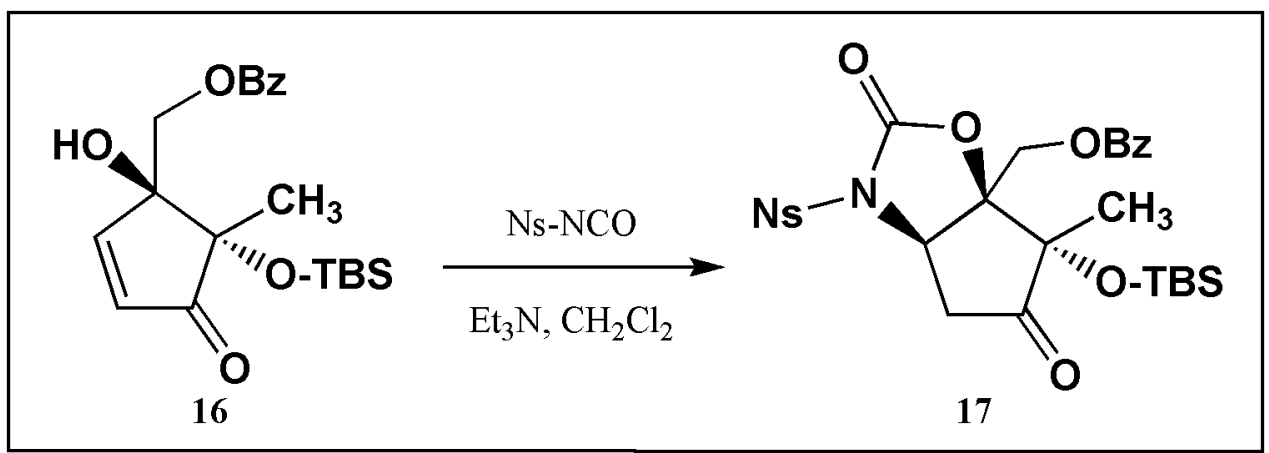

Compound 17. A solution of $16(20 \mathrm{mg}, 0.053 \mathrm{mmol})$ in $1 \mathrm{~mL}$ of dry dichloromethane was stirred at $0{ }^{\circ} \mathrm{C}$. 2-Nitrobenzenesulfonyl isocyanate stock solution ( $0.3 \mathrm{~mL}$, prepared as above) was added, followed by $15 \mathrm{uL}(0.106 \mathrm{mmol}, 2.0$ equiv) of triethylamine. The reaction mixture was allowed to stir at room temperature overnight. Dichloromethane $(10 \mathrm{~mL})$ was added to the solution, which was then cooled to $0{ }^{\circ} \mathrm{C}$ and quenched with $2 \mathrm{ml}$ of saturated aqueous ammonium chloride. The organic layer was reserved, and the aqueous layer was further extracted with dichloromethane $(2 \times 4 \mathrm{~mL})$. The combined organic extract was washed with brine $(4 \mathrm{~mL})$, dried with anhydrous sodium sulfate, and then concentrated. The crude product was purified by flash chromatography on silica, eluting with $20 \%$ ethyl acetate in hexanes $\left(R_{f}=0.25\right)$, to provide 17 as a white solid (29 mg, 90\% yield), mp 69-71 ${ }^{\circ} \mathrm{C} .{ }^{1} \mathrm{H}$ NMR $\left(\mathrm{CDCl}_{3}, 400\right.$ MHz) $\delta 8.44(\mathrm{dd}, J=7.4 \mathrm{~Hz}, 1.2 \mathrm{~Hz}, 1 \mathrm{H}), 7.80$ - 7.67 (m, $4 \mathrm{H}), 7.47$ - 7.43 (m, $2 \mathrm{H})$, $7.22-7.18$ (m, 2 H), 5.07 (dd, $J=9.6 \mathrm{~Hz}, 2.8 \mathrm{~Hz}, 1 \mathrm{H}), 5.05$ (d, $J=12.4 \mathrm{~Hz}, 1 \mathrm{H}), 4.57$ (d, $J=12.4 \mathrm{~Hz}, 1 \mathrm{H}), 3.37$ (dd, $J=19.6 \mathrm{~Hz}, 9.6 \mathrm{~Hz}, 1 \mathrm{H}), 2.80$ (dd, $J=19.4 \mathrm{~Hz}, 2.6 \mathrm{~Hz}$, $1 \mathrm{H}), 1.54(\mathrm{~s}, 3 \mathrm{H}), 0.90(\mathrm{~s}, 9 \mathrm{H}), 0.18(\mathrm{~s}, 3 \mathrm{H}), 0.08(\mathrm{~s}, 3 \mathrm{H}) ;{ }^{13} \mathrm{C} \mathrm{NMR}\left(\mathrm{CDCl}_{3}, 400\right.$ MHz) $\delta 207.2,165.2,149.9,147.5,135.6,134.5,132.9,132.2,130.0,129.2,129.0$, $128.4,124.5,87.6,79.8,63.6,58.0,41.9,25.7,18.3,16.0,-2.2,-3.6$; IR (neat) 1798, 1766, 1729, $1546 \mathrm{~cm}^{-1}$; ESI-MS m/z $627 \mathrm{MNa}^{+}$; FAB-HRMS calcd for $\mathrm{C}_{27} \mathrm{H}_{33} \mathrm{O}_{10} \mathrm{SSi}$ 605.1625 , found 605.1598 . 


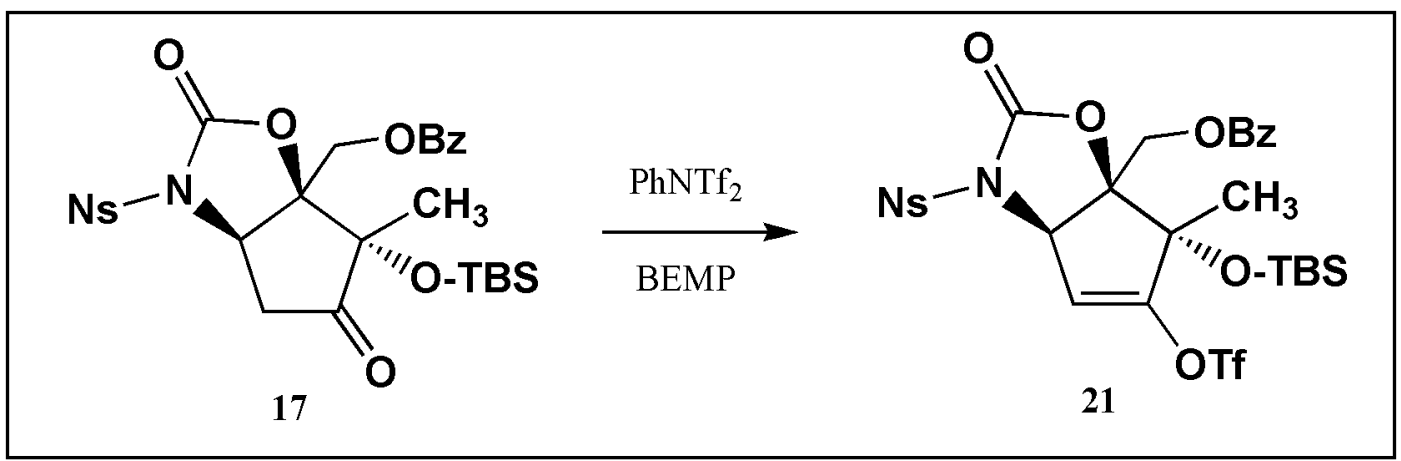

Compound 21. A solution of $86 \mathrm{mg}(0.142 \mathrm{mmol})$ of 17 and $152 \mathrm{mg}(0.426$ mmol, 3.0 equiv) of $N$-phenyl-bis(trifluoromethanesulfonimide) in $3 \mathrm{~mL}$ of dry THF was stirred at $0 \quad{ }^{\circ} \mathrm{C}$. 2-tert-Butylimino-2-diethylamino-1,3-dimethyl-perhydro-1,3,2diazaphosphorine (BEMP, $82 \mathrm{uL}, 0.284 \mathrm{mmol}, 2.0$ equiv) was added slowly. The reaction mixture was allowed to stir at room temperature overnight, cooled to $0{ }^{\circ} \mathrm{C}$, and then was quenched by addition of $3 \mathrm{~mL}$ of brine. Following extraction with ethyl acetate $(3 \times 10$ $\mathrm{mL})$, the combined organic layer was washed with brine $(5 \mathrm{~mL})$, dried with anhydrous sodium sulfate, and then concentrated. The crude product was purified by flash chromatography on silica, eluting with $20 \%$ ethyl acetate in hexanes $\left(R_{f}=0.25\right)$, to provide 21 as a white solid (105 mg, quantitative yield), mp 152-154 ${ }^{\circ} \mathrm{C} .{ }^{1} \mathrm{H}$ NMR $\left(\mathrm{CDCl}_{3}, 400 \mathrm{MHz}\right) \delta 8.44(\mathrm{~d}, J=8.4 \mathrm{~Hz}, 1 \mathrm{H}), 7.80-7.65(\mathrm{~m}, 4 \mathrm{H}), 7.45-7.37$ (m, 2 H), $7.16-7.12(\mathrm{~m}, 2 \mathrm{H}), 6.15(\mathrm{~d}, J=2.0 \mathrm{~Hz}, 1 \mathrm{H}), 5.49(\mathrm{~d}, J=1.6 \mathrm{~Hz}, 1 \mathrm{H}), 5.00(\mathrm{~d}, J=$ $13.2 \mathrm{~Hz}, 1 \mathrm{H}), 4.45$ (d, $J=12.4 \mathrm{~Hz}, 1 \mathrm{H}), 1.65$ (s, $3 \mathrm{H}), 0.92(\mathrm{~s}, 9 \mathrm{H}), 0.21(\mathrm{~s}, 6 \mathrm{H}) ;{ }^{13} \mathrm{C}$ $\mathrm{NMR}\left(\mathrm{CDCl}_{3}, 400 \mathrm{MHz}\right) \delta 165.2,154.1,149.6,147.5,135.5,134.3,132.8,132.2,130.1$, 129.2, 129.0, 128.3, 124.4, 119.9, 116.8, 112.4, 87.7, 83.7, 64.04, 63.99, 25.7, 20.2, 18.4, -2.2, -2.7; IR (neat) 1797, 1731, $1658,1547 \mathrm{~cm}^{-1}$; ESI-MS $m / z 759 \mathrm{MNa}^{+}$; FAB-HRMS calcd for $\mathrm{C}_{28} \mathrm{H}_{32} \mathrm{~F}_{3} \mathrm{~N}_{2} \mathrm{O}_{12} \mathrm{~S}_{2} \mathrm{Si} 737.1118$, found 737.1102. 


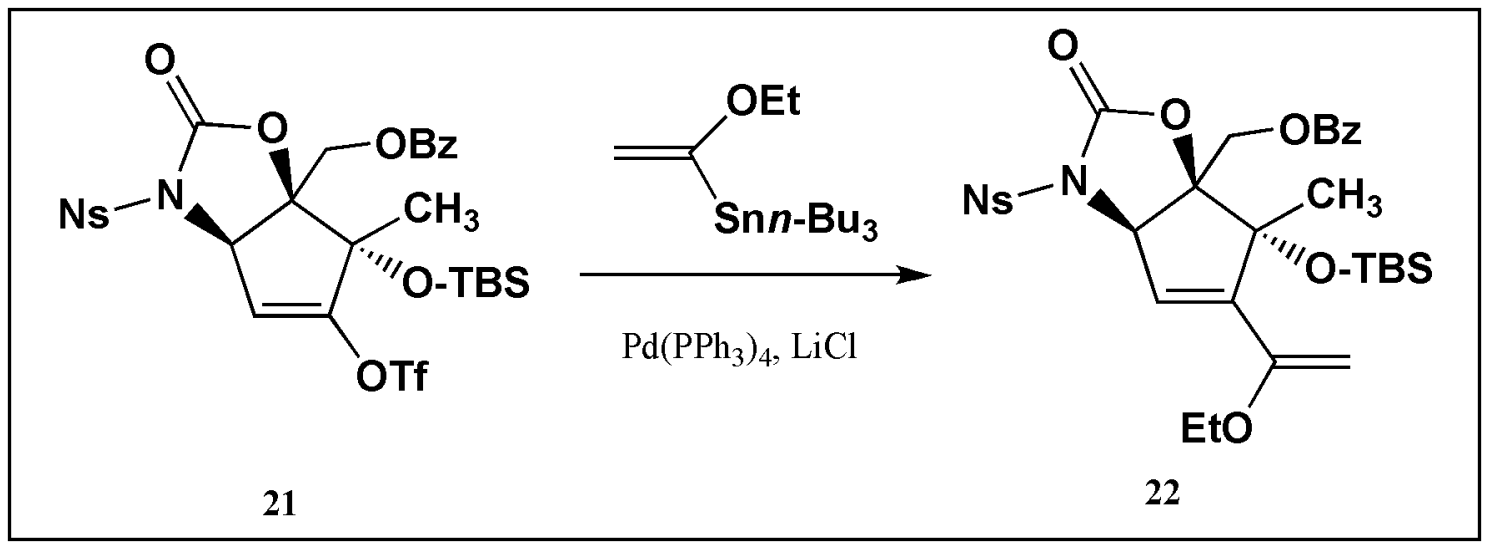

Compound 22. A solution of 21 (20 mg, $0.027 \mathrm{mmol})$, lithium chloride (2.3 mg, $0.054 \mathrm{mmol}, 2.0$ equiv), tetrakis(triphenylphosphine)palladium $(3.1 \mathrm{mg}, 0.0027 \mathrm{mmol}$, 0.1 equiv), and tri- $n$-butyl(1-ethoxy-vinyl)tin (64 $u \mathrm{~L}, 0.189 \mathrm{mmol}, 7.0$ equiv) in $0.5 \mathrm{~mL}$ of THF was stirred at room temperature for $1 \mathrm{~h}$, then was heated at reflux for $18 \mathrm{~h}$. The black suspension was cooled to room temperature, diluted with $10 \mathrm{~mL}$ of ethyl acetate, filtered, and then washed sequentially with brine $(10 \mathrm{~mL})$ and $5 \%$ aqueous ammonium hydroxide $(2 \mathrm{~mL})$. The organic solution was dried over anhydrous sodium sulfate, and then concentrated. The product was purified by using preparative silica TLC, eluting with 26\% ethyl acetate in hexanes, to give 22 as a white solid (13 mg, 73\% yield), $\mathrm{mp}$ 96-98 ${ }^{\circ} \mathrm{C} .{ }^{1} \mathrm{H} \mathrm{NMR}\left(\mathrm{CDCl}_{3}, 400 \mathrm{MHz}\right) \delta 8.45(\mathrm{~d}, J=6.4 \mathrm{~Hz}, 1 \mathrm{H}), 7.75(\mathrm{t}, J=7.4 \mathrm{~Hz}, 1 \mathrm{H})$, $7.64-7.61$ (m, $3 \mathrm{H}), 7.39$ (t, $J=7.4 \mathrm{~Hz}, 1 \mathrm{H}), 7.33$ (d, $J=8.0 \mathrm{~Hz}, 1 \mathrm{H}), 7.09$ (t, $J=7.6$ $\mathrm{Hz}, 2 \mathrm{H}), 6.29$ (d, $J=1.6 \mathrm{~Hz}, 1 \mathrm{H}), 5.39$ (d, $J=2.4 \mathrm{~Hz}, 1 \mathrm{H}), 5.01$ (d, $J=12.4 \mathrm{~Hz}, 1 \mathrm{H})$, $4.49(\mathrm{~d}, J=2.4 \mathrm{~Hz}, 1 \mathrm{H}), 4.45(\mathrm{~d}, J=12.4 \mathrm{~Hz}, 1 \mathrm{H}), 4.24$ (d, $J=2.4 \mathrm{~Hz}, 1 \mathrm{H}), 3.79$ (q, $J$ $=7.2 \mathrm{~Hz}, 2 \mathrm{H}), 1.75(\mathrm{~s}, 3 \mathrm{H}), 1.37(\mathrm{t}, J=7.0 \mathrm{~Hz}, 3 \mathrm{H}), 0.90(\mathrm{~s}, 9 \mathrm{H}), 0.16(\mathrm{~s}, 3 \mathrm{H}) ; 0.14(\mathrm{~s}$, $3 \mathrm{H}) ;{ }^{13} \mathrm{C} \mathrm{NMR}\left(\mathrm{CDCl}_{3}, 400 \mathrm{MHz}\right) \delta 165.4,155.3,150.4,148.6,147.5,135.1,134.2$, $132.5,131.9,130.5,129.4,129.1,128.2,127.4,124.2,91.4,88.0,86.9,66.6,64.4,63.2$, 26.0, 22.9, 18.6, 14.6, -2.1, -2.3; ESI-MS $m / z 631 \mathrm{MH}^{+}, 681 \mathrm{MNa}^{+}$. 


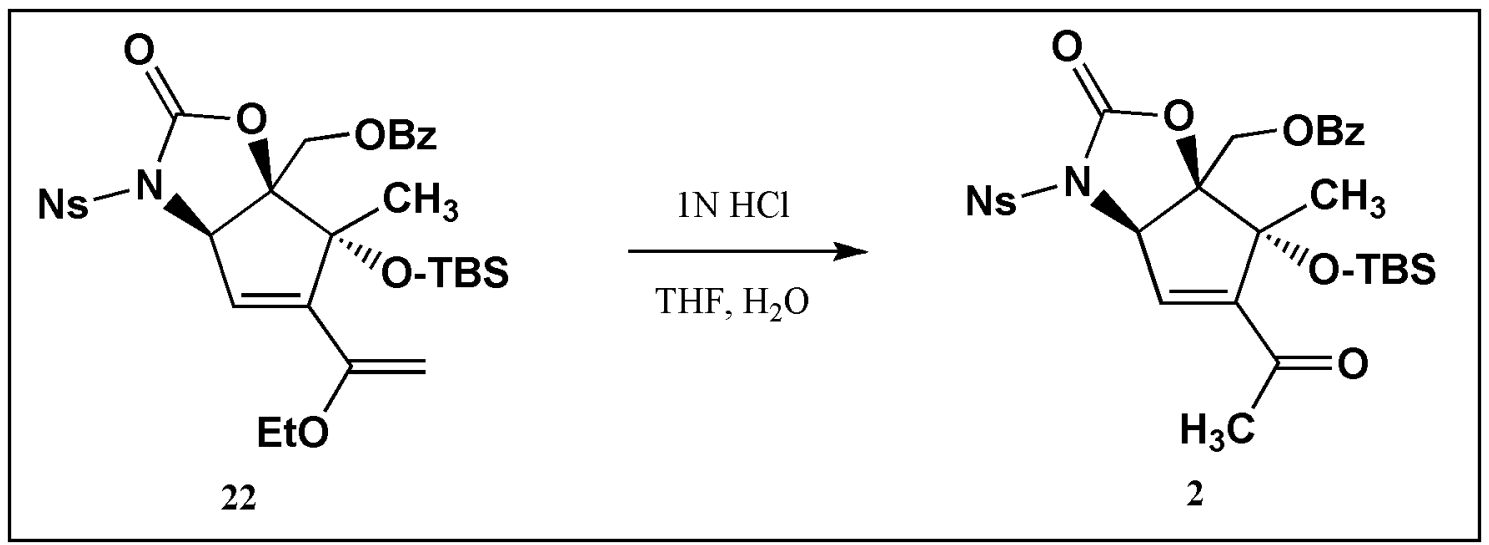

Compound 2. A mixture of 22 (10 mg, $0.0152 \mathrm{mmol}), 0.5 \mathrm{~mL}$ of THF, and 0.15 $\mathrm{mL}$ of $1 \mathrm{~N}$ hydrochloric acid was stirred at room temperature for $3 \mathrm{~h}$, then partitioned between $5 \mathrm{~mL}$ of ethyl acetate and $1 \mathrm{~mL}$ of water. The organic layer was dried with anhydrous sodium sulfate, and then concentrated. The product was purified by flash chromatography on silica, eluting with $15 \%$ ethyl acetate in hexanes $\left(R_{f}=0.2\right)$, to afford 2 as a white solid $(8 \mathrm{mg}, 83 \%$ yield $), \mathrm{mp} 112-114{ }^{\circ} \mathrm{C} .{ }^{1} \mathrm{H}$ NMR $\left(\mathrm{CDCl}_{3}, 400 \mathrm{MHz}\right)$ $\delta 8.45(\mathrm{dd}, J=8.2 \mathrm{~Hz}, 1.4 \mathrm{~Hz}, 1 \mathrm{H}), 7.78-7.74(\mathrm{~m}, 1 \mathrm{H}), 7.65-7.60$ (m, $3 \mathrm{H}), 7.42$ $7.38(\mathrm{~m}, 1 \mathrm{H}), 7.32-7.29(\mathrm{~m}, 1 \mathrm{H}), 7.12-7.08$ (m, $2 \mathrm{H}), 6.90(\mathrm{~d}, J=2.0 \mathrm{~Hz}, 1 \mathrm{H}), 5.54$ $(\mathrm{d}, J=1.6 \mathrm{~Hz}, 1 \mathrm{H}), 5.13(\mathrm{~d}, J=13.2 \mathrm{~Hz}, 1 \mathrm{H}), 4.41(\mathrm{~d}, J=12.4 \mathrm{~Hz}, 1 \mathrm{H}), 2.45$ (s, $3 \mathrm{H})$, $1.81(\mathrm{~s}, 3 \mathrm{H}), 0.88$ (s, $9 \mathrm{H}), 0.22(\mathrm{~s}, 3 \mathrm{H}) ; 0.08$ (s, $3 \mathrm{H}) ;{ }^{13} \mathrm{C} \mathrm{NMR}\left(\mathrm{CDCl}_{3}, 400 \mathrm{MHz}\right)$ $\delta 195.5,165.3,149.9,148.6,139.0,135.5,134.2,132.6,132.1,130.1,129.2,129.1$, $128.3,124.3,91.2,86.5,66.8,64.3,29.9,28.8,25.9,21.2,18.6,-2.2,-2.8$; IR (neat) 1791, 1728, 1688, $1546 \mathrm{~cm}^{-1}$; ESI-MS $m / z 631 \mathrm{MH}^{+}, 653 \mathrm{MNa}^{+}$; FAB-HRMS calcd for $\mathrm{C}_{29} \mathrm{H}_{35} \mathrm{~N}_{2} \mathrm{O}_{10} \mathrm{SSi}$ 631.1782, found 631.1782. 


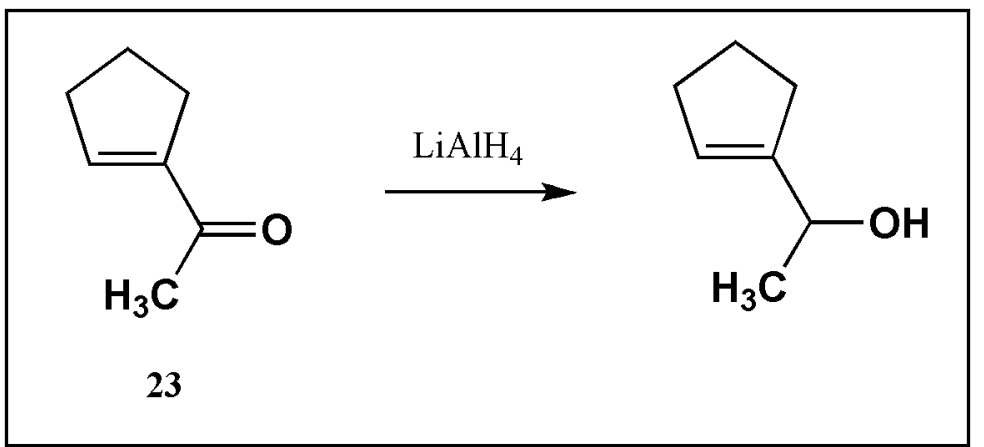

1-(1-Hydroxyethyl)cyclopentene. A solution of $5.00 \mathrm{~g}(45.4 \mathrm{mmol})$ of 1acetylcyclopentene $\mathbf{( 2 3 )}$ in $20 \mathrm{~mL}$ of diethyl ether was added dropwise over a 20 min period to a stirred solution of $12.5 \mathrm{~mL}$ of lithium aluminum hydride $(1.0 \mathrm{~N}$ in diethyl ether, $12.5 \mathrm{mmol}, 0.275$ equiv) in $35 \mathrm{~mL}$ of diethyl ether at $0{ }^{\circ} \mathrm{C}$ under a nitrogen atmosphere. The reaction mixture was allowed to stir overnight at $23{ }^{\circ} \mathrm{C}$, was cooled to 0 ${ }^{\circ} \mathrm{C}$, and then was quenched by dropwise addition of $3 \mathrm{~mL}$ of water. The mixture was poured into $20 \mathrm{~mL}$ of $1 \mathrm{~N}$ aq hydrochloric acid, which in turn was extracted with diethyl ether $(3$ X $30 \mathrm{~mL})$. The combined organic extract was washed with water $(30 \mathrm{~mL})$ and brine $(30 \mathrm{~mL})$, dried over anhydrous magnesium sulfate, and then concentrated. The crude product was chromatographed on silica with ethyl acetate / hexanes as the eluant to provide $4.5 \mathrm{~g}(88 \%)$ of the racemic carbinol as a colorless oil. ${ }^{1} \mathrm{H}$ NMR $\left(\mathrm{CDCl}_{3}, 400\right.$ MHz) $\oint 5.58($ br s, $1 \mathrm{H}), 4.41$ (q, $J=6.4 \mathrm{~Hz}, 1 \mathrm{H}), 2.32$ (t, $J=7.6 \mathrm{~Hz}, 4 \mathrm{H}), 1.89$ (quint, $J$ $=7.6 \mathrm{~Hz}, 2 \mathrm{H}), 1.59$ (br s, OH), $1.30(\mathrm{~d}, J=6.4 \mathrm{~Hz}, 3 \mathrm{H}) ;{ }^{13} \mathrm{C} \mathrm{NMR}\left(\mathrm{CDCl}_{3}, 400 \mathrm{MHz}\right) \oint$ $148.2,124.1,67.3,32.3,31.5,23.5,22.2$. 


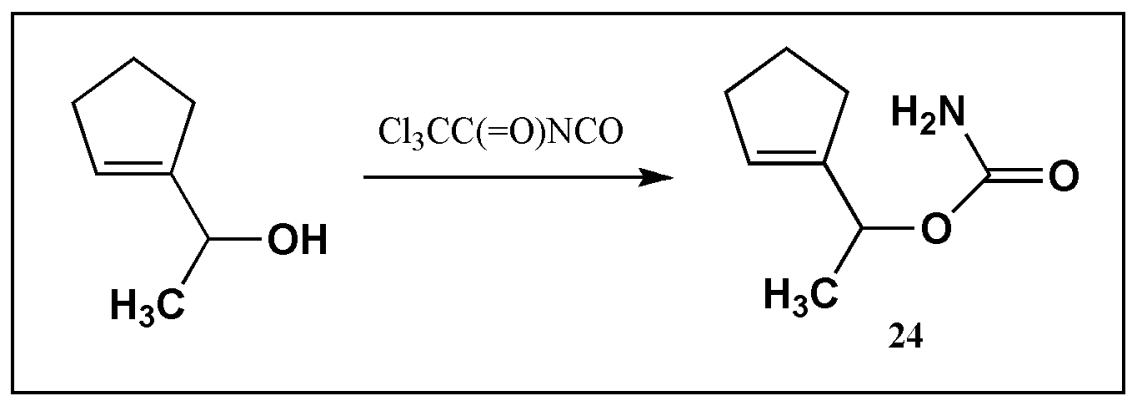

Carbamic acid (1-cyclopentenyl)-1-ethyl ester (24). Trichloroacetylisocyanate (0.64 $\mathrm{mL}, 5.4 \mathrm{mmol})$ was added to a solution of $0.30 \mathrm{~g}(2.7 \mathrm{mmol})$ of the carbinol in 15 $\mathrm{mL}$ of dry dichloromethane. After $3 \mathrm{~h}, 15 \mathrm{~mL}$ of methanol and $2.0 \mathrm{~g}$ of potassium carbonate were added. The mixture was stirred at room temperature overnight, filtered through a Celite pad, and then extracted into dichloromethane (2 X $10 \mathrm{~mL})$. The organic extract was concentrated and then chromatographed on silica with ethyl acetate / hexanes as the eluant to provide $0.38 \mathrm{~g}(91 \%)$ of 24 as a white solid, mp $63-64{ }^{\circ} \mathrm{C} .{ }^{1} \mathrm{H}$ NMR $\left(\mathrm{CDCl}_{3}, 400 \mathrm{MHz}\right) \delta 5.61(\mathrm{~d}, J=1.6 \mathrm{~Hz}, 1 \mathrm{H}), 5.35(\mathrm{q}, J=6.4 \mathrm{~Hz}, 1 \mathrm{H}), 4.87$ (br s, 2 $\mathrm{NH}), 2.34-2.27(\mathrm{~m}, 4 \mathrm{H}), 1.91-1.84(\mathrm{~m}, 2 \mathrm{H}), 1.33(\mathrm{~d}, J=6.4 \mathrm{~Hz}, 3 \mathrm{H}) ;{ }^{13} \mathrm{C} \mathrm{NMR}$ $\left(\mathrm{CDCl}_{3}, 400 \mathrm{MHz}\right) \oint 156.6,144.0,126.0,70.2,32.4,31.9,23.3,19.5$; IR (neat) 3429, 3266, 3211, $1684 \mathrm{~cm}^{-1}$; ESI-MS $m / z 178 \mathrm{MNa}^{+}$.

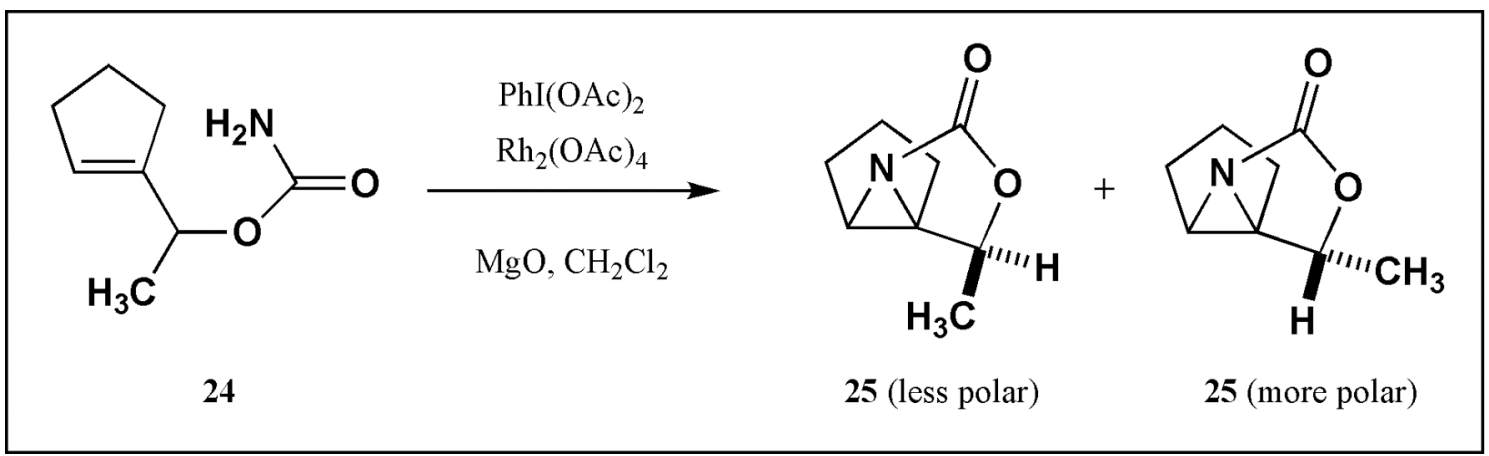


$\mathrm{N}$-Acyl-aziridines 25. A mixture of $0.12 \mathrm{~g}(0.77 \mathrm{mmol})$ of carbamate $24,161 \mathrm{mg}$ (4.0 mmol) of activated $\mathrm{MgO}, 386 \mathrm{mg}(1.2 \mathrm{mmol})$ of $\mathrm{PhI}(\mathrm{OAc})_{2}, 35 \mathrm{mg}(0.08 \mathrm{mmol})$ of $\mathrm{Rh}_{2}(\mathrm{OAc})_{4}$, and $6 \mathrm{~mL}$ of dry dichloromethane was heated at $40{ }^{\circ} \mathrm{C}$ for $12 \mathrm{~h}$ in a sealed tube. The reaction mixture was cooled, filtered through Celite, and then rinsed with dichloromethane $(2 \times 5 \mathrm{~mL})$. The combined extract was concentrated and then chromatographed on silica with $30 \%$ ethyl acetate in hexanes as the eluant to give $45 \mathrm{mg}$ (38\%) of the less polar isomer $25, \mathrm{mp} 60-61{ }^{\circ} \mathrm{C}$, and $38 \mathrm{mg}(32 \%)$ of the more polar isomer 25, mp 60-62 ${ }^{\circ} \mathrm{C}$. Data for 25 (less polar): ${ }^{1} \mathrm{H}$ NMR $\left(\mathrm{CDCl}_{3}, 400 \mathrm{MHz}\right) \delta 4.82$ (q, $J=6.2 \mathrm{~Hz}, 1 \mathrm{H}), 3.01(\mathrm{~d}, J=1.6 \mathrm{~Hz}, 1 \mathrm{H}), 2.18-2.13(\mathrm{~m}, 1 \mathrm{H}), 2.04-1.99(\mathrm{~m}, 1 \mathrm{H})$, $1.83-1.68(\mathrm{~m}, 3 \mathrm{H}), 1.54-1.48(\mathrm{~m}, 1 \mathrm{H}), 1.46(\mathrm{~d}, J=6.0 \mathrm{~Hz}, 3 \mathrm{H}) ;{ }^{13} \mathrm{C} \mathrm{NMR}\left(\mathrm{CDCl}_{3}\right.$, $400 \mathrm{MHz}) \oint 166.3,74.6,61.1,50.8,27.7,26.5,19.9,17.4$; IR (neat) $1767 \mathrm{~cm}^{-1}$; ESI-MS $m / z 154 \mathrm{MH}^{+}$. Data for 25 (more polar): ${ }^{1} \mathrm{H}$ NMR $\left(\mathrm{CDCl}_{3}, 400 \mathrm{MHz}\right) \oint 4.88(\mathrm{q}, J=6.2$ $\mathrm{Hz}, 1 \mathrm{H}), 2.96(\mathrm{~d}, J=2.8 \mathrm{~Hz}, 1 \mathrm{H}), 2.18-2.06(\mathrm{~m}, 2 \mathrm{H}), 1.84-1.67(\mathrm{~m}, 3 \mathrm{H}), 1.51-$

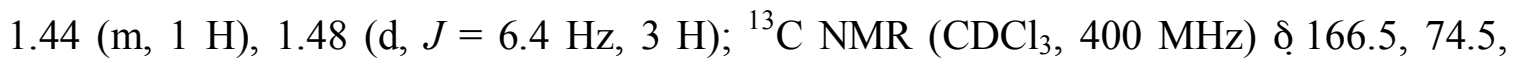
60.0, 53.4, 27.8, 25.2, 20.1, 19.5; IR (neat) $1768 \mathrm{~cm}^{-1}$; ESI-MS $m / z 154 \mathrm{MH}^{+}$.

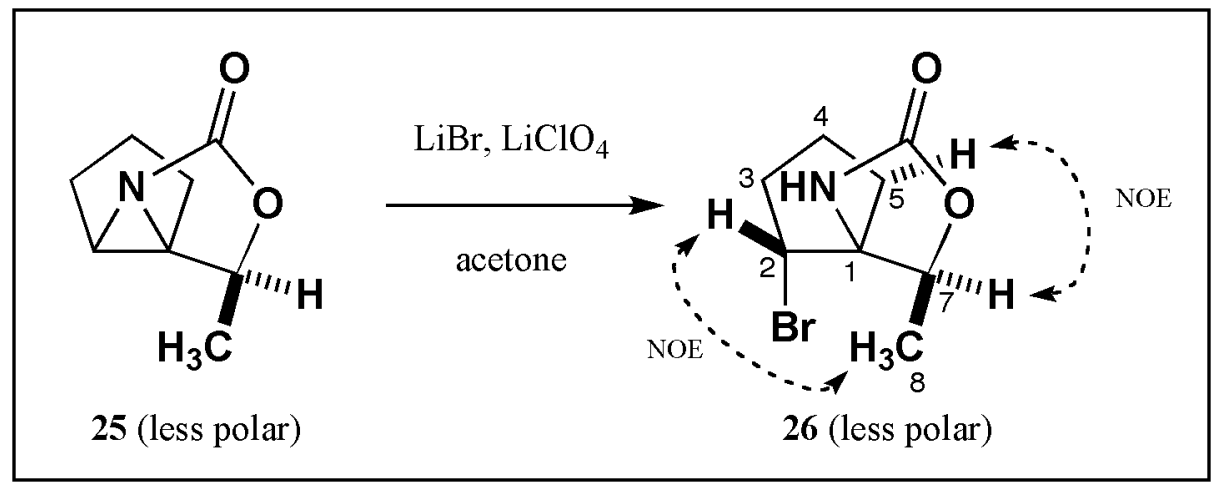

Bromo Oxazolidinone 26 (less polar). A solution of $40 \mathrm{mg}(0.26 \mathrm{mmol})$ of 25 (less polar isomer), $95 \mathrm{mg}(1.1 \mathrm{mmol})$ of lithium bromide, and $4 \mathrm{mg}$ of lithium 
perchlorate in $3 \mathrm{~mL}$ of dry acetone was stirred at $23{ }^{\circ} \mathrm{C}$ overnight, concentrated, and then chromatographed on silica with $40 \%$ ethyl acetate in hexanes as the eluant to afford 48 mg (79\%) of 26 (less polar isomer), mp $121-123{ }^{\circ} \mathrm{C}:{ }^{1} \mathrm{H} \mathrm{NMR}\left(\mathrm{CDCl}_{3}, 400 \mathrm{MHz}\right.$, stereochemistry from NOESY) $\oint 7.23$ (br s, NH), 4.54 (q, $J=6.0 \mathrm{~Hz}, \mathrm{H}-7), 4.17$ (d, $J=$ $4.4 \mathrm{~Hz}, \mathrm{H}-2), 2.39-2.22(\mathrm{~m}, 3 \mathrm{H}), 2.12-1.87(\mathrm{~m}, 3 \mathrm{H}), 1.59(\mathrm{~d}, J=5.6 \mathrm{~Hz}, \mathrm{H}-8) ;{ }^{13} \mathrm{C}$ NMR $\left(\mathrm{CDCl}_{3}, 400 \mathrm{MHz}\right)$ ọ 159.4, 80.6, 72.7, 54.0, 35.2, 34.7, 18.9, 16.6; IR (neat) 3251, 3131, $1747 \mathrm{~cm}^{-1}$; ESI-MS $\mathrm{m} / z 234$ and $236 \mathrm{MH}^{+}$.

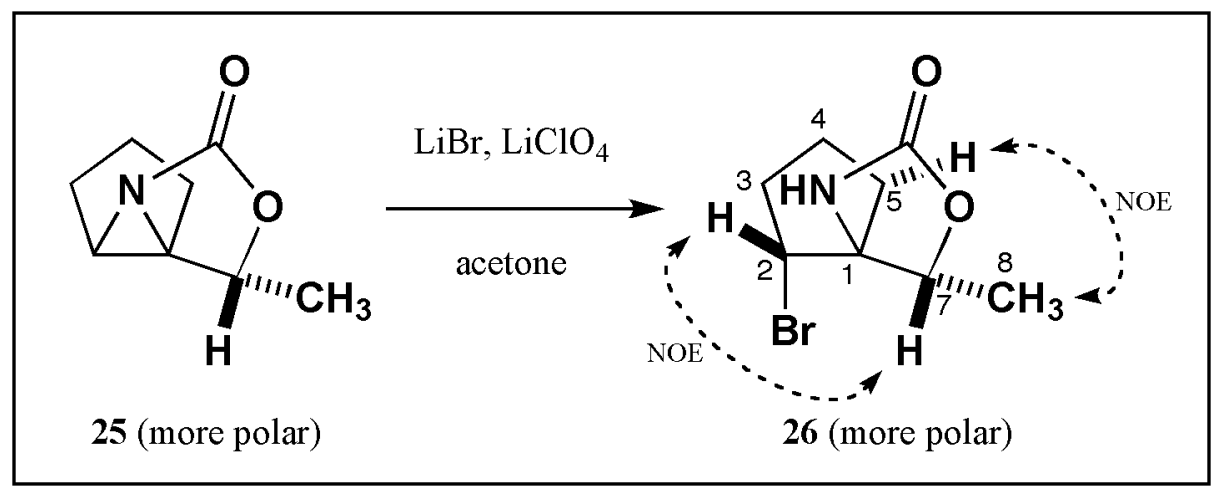

Bromo Oxazolidinone 26 (more polar). A $34 \mathrm{mg}$ sample $(0.22 \mathrm{mmol})$ of 25 (more polar isomer) was treated with lithium bromide and a catalytic amount of $\mathrm{LiClO}_{4}$ as above. Chromatography afforded $43 \mathrm{mg}$ (84\%) of 26 (more polar isomer), $\mathrm{mp} 108$ $109{ }^{\circ} \mathrm{C} .{ }^{1} \mathrm{H} \mathrm{NMR}\left(\mathrm{CDCl}_{3}, 400 \mathrm{MHz}\right.$, stereochemistry from NOESY) $\delta 6.76$ (br s, NH), $4.94(\mathrm{q}, J=6.4 \mathrm{~Hz}, \mathrm{H}-7), 4.22(\mathrm{~d}, J=5.2 \mathrm{~Hz}, \mathrm{H}-2), 2.44-2.34(\mathrm{~m}, 1 \mathrm{H}), 2.30-2.17$ (m, $2 \mathrm{H}), 2.04-1.93(\mathrm{~m}, 1 \mathrm{H}), 1.90-1.72(\mathrm{~m}, 2 \mathrm{H}), 1.43(\mathrm{~d}, J=6.4 \mathrm{~Hz}, \mathrm{H}-8) ;{ }^{13} \mathrm{C}$ NMR $\left(\mathrm{CDCl}_{3}, 400 \mathrm{MHz}\right) \oint 158.0,78.7,71.6,59.7,33.3,29.2,19.4,17.9$; IR (neat) 3212, 3133, $1748 \mathrm{~cm}^{-1}$; ESI-MS $\mathrm{m} / z 234$ and $236 \mathrm{MH}^{+}$. 


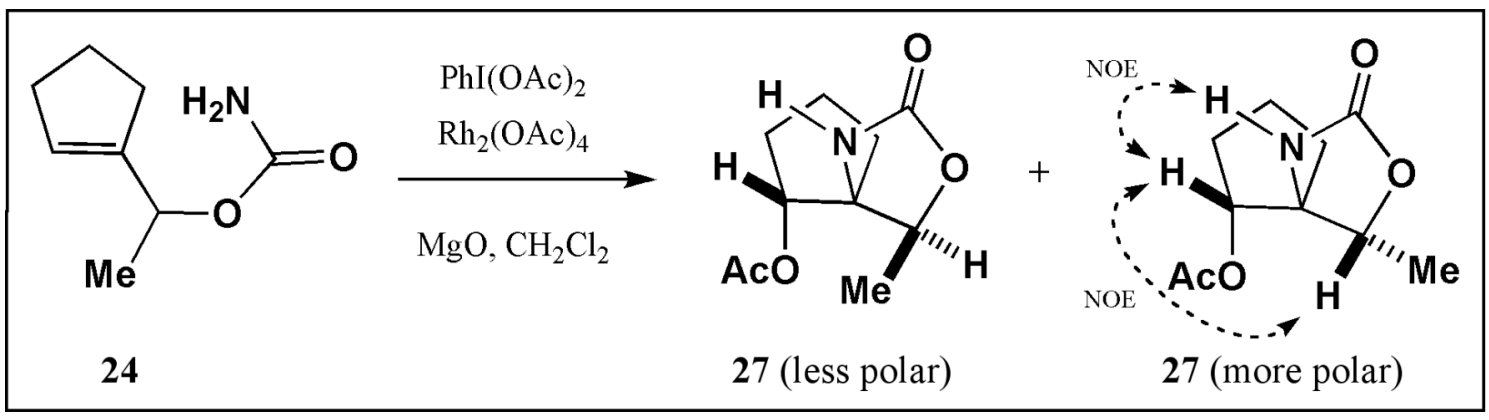

Acetoxy Oxazolidinones 27. A mixture of $0.12 \mathrm{~g}(0.77 \mathrm{mmol})$ of carbamate 24 (0.12 g, $0.77 \mathrm{mmol}), 161 \mathrm{mg}(4.0 \mathrm{mmol})$ of activated $\mathrm{MgO}, 386 \mathrm{mg}(1.2 \mathrm{mmol})$ of $\mathrm{PhI}(\mathrm{OAc})_{2}, 35 \mathrm{mg}(0.08 \mathrm{mmol})$ of $\mathrm{PhI}(\mathrm{OAc})_{2}$, and $4 \mathrm{~mL}$ of dry dichloromethane was heated at $90{ }^{\circ} \mathrm{C}$ in a sealed tube for 4 days. The reaction mixture cooled, filtered through Celite, and then rinsed with dichloromethane $(3 \times 10 \mathrm{~mL})$. The combined organic extract was concentrated and then chromatographed on silica with $40 \%$ ethyl acetate in hexanes as the eluant to give $51 \mathrm{mg}(31 \%)$ of the less polar isomer $27, \mathrm{mp} 98-100{ }^{\circ} \mathrm{C}$, and $66 \mathrm{mg}$ (40\%) of the more polar isomer 27 (structure based on NOE crosspeaks; see structure above), mp $99-101{ }^{\circ} \mathrm{C}$. The more polar isomer of 27 forms somewhat faster than the less polar isomer under these conditions. Data for 27 (less polar isomer): ${ }^{1} \mathrm{H} \mathrm{NMR}\left(\mathrm{CDCl}_{3}\right.$,

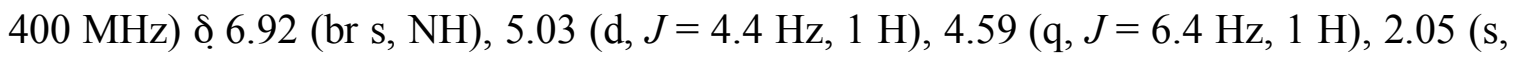
$3 \mathrm{H}), 2.07-1.96(\mathrm{~m}, 3 \mathrm{H}), 1.86-1.78(\mathrm{~m}, 3 \mathrm{H}), 1.39(\mathrm{~d}, J=6.4 \mathrm{~Hz}, 3 \mathrm{H}) ;{ }^{13} \mathrm{C} \mathrm{NMR}$ $\left(\mathrm{CDCl}_{3}, 400 \mathrm{MHz}\right) \oint 169.4,158.8,79.3,78.0,69.9,35.9,30.0,21.4,18.7,16.7$; IR (neat) 3259, $1751 \mathrm{~cm}^{-1}$; ESI-MS m/z $214 \mathrm{MH}^{+}$. Data for 27 (more polar isomer): ${ }^{1} \mathrm{H}$ NMR $\left(\mathrm{CDCl}_{3}, 400 \mathrm{MHz}\right.$, stereochemistry by NOESY) $\delta 6.88$ (br s, NH), 4.97 (dd, $J=5.6,2.8$ Hz, $1 \mathrm{H}), 4.72(\mathrm{q}, J=6.4 \mathrm{~Hz}, 1 \mathrm{H}), 2.20-2.11(\mathrm{~m}, 1 \mathrm{H}), 2.06(\mathrm{~s}, 3 \mathrm{H}), 1.98-1.91(\mathrm{~m}, 1$ $\mathrm{H}), 1.82-1.63(\mathrm{~m}, 4 \mathrm{H}), 1.38(\mathrm{~d}, J=6.4 \mathrm{~Hz}, 3 \mathrm{H}) ;{ }^{13} \mathrm{C} \mathrm{NMR}\left(\mathrm{CDCl}_{3}, 400 \mathrm{MHz}\right) \oint 170.2$, 
Spencer Knapp and Younong Yu, "Synthesis of the Oxygenated Pactamycin Core"

159.1, 80.5, 76.2, 70.0, 30.2, 29.3, 21.3, 19.5, 17.4; IR (neat) 3260, $1749 \mathrm{~cm}^{-1}$; ESI-MS $m / z 214 \mathrm{MH}^{+}$. 

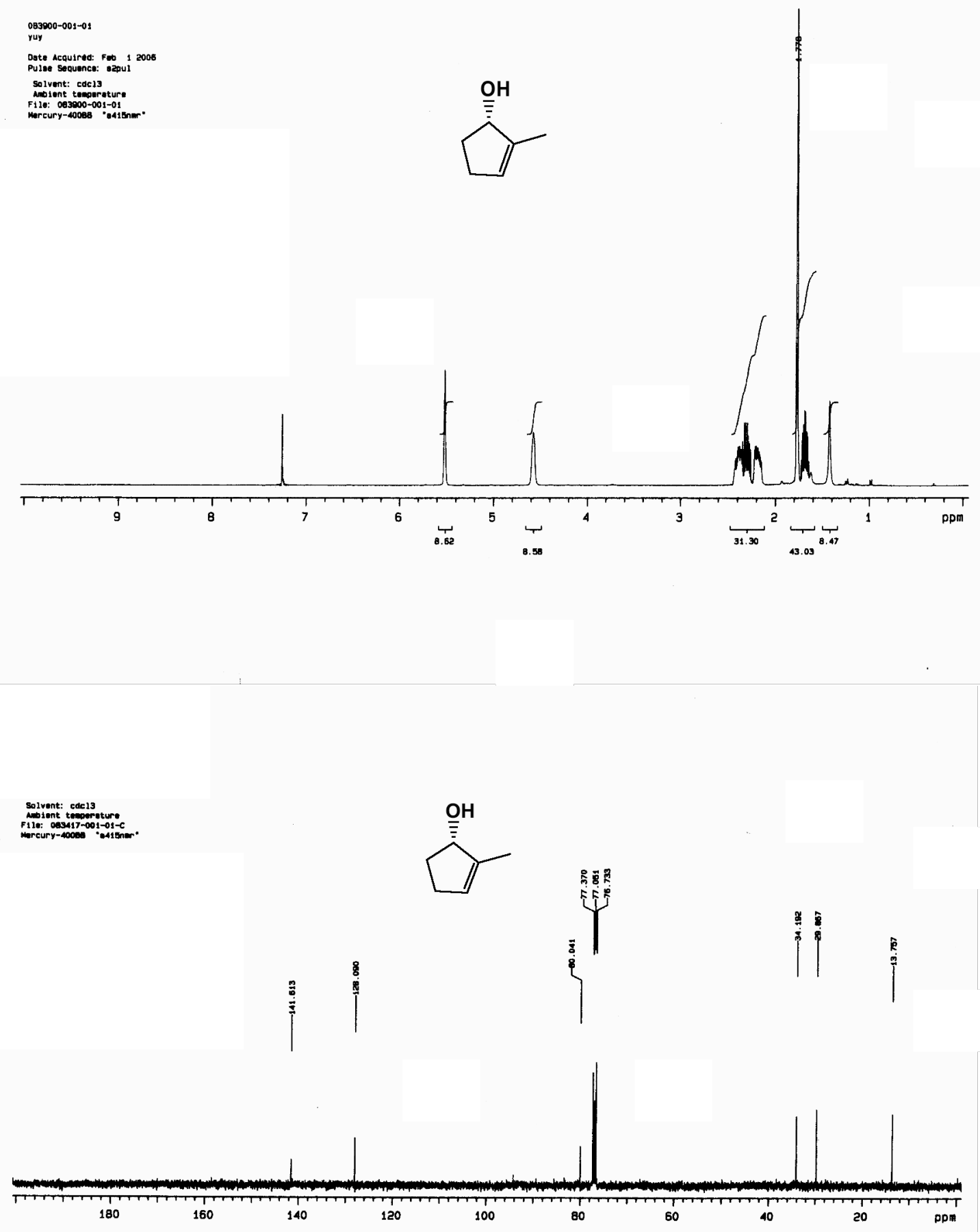

${ }^{1} \mathrm{H}$ and ${ }^{13} \mathrm{C}$ NMR spectra of $4\left(\mathrm{CDCl}_{3}\right)$ 

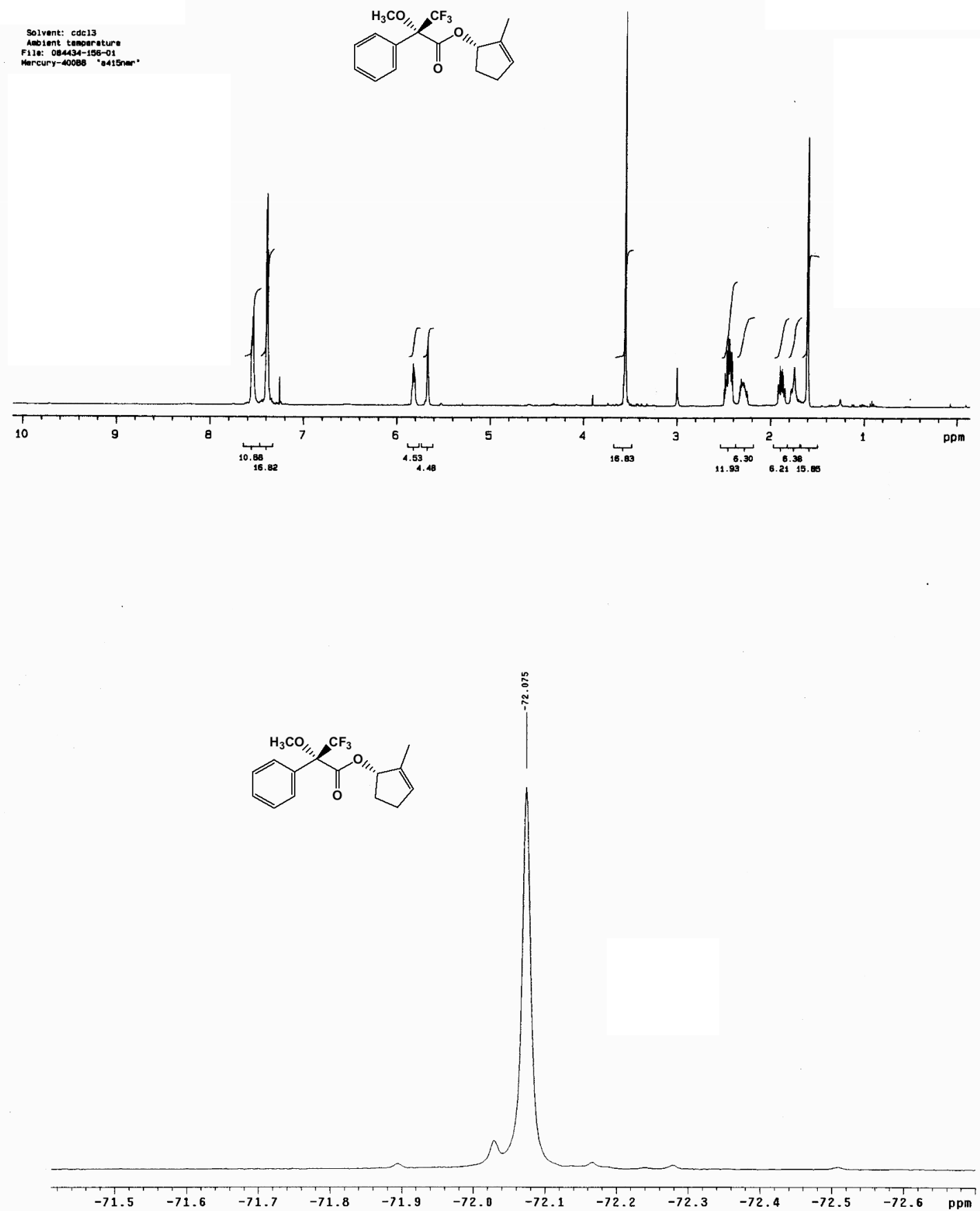

${ }^{1} \mathrm{H}$ and ${ }^{19} \mathrm{~F}$ NMR spectra of the crude Mosher ester of $4\left(\mathrm{CDCl}_{3}\right)$ 


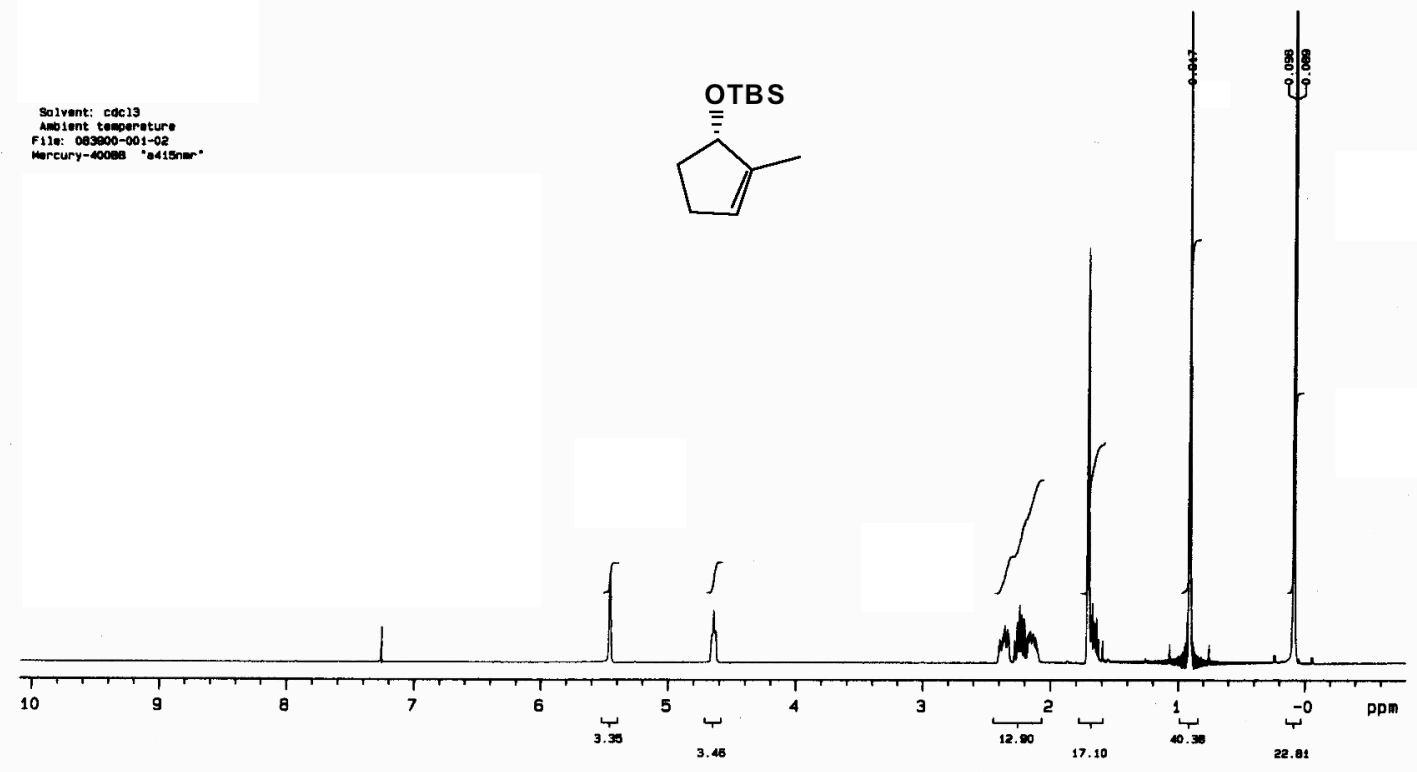

Selvent: coecis

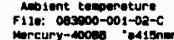

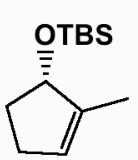

$\stackrel{8}{\mathbf{8}}$

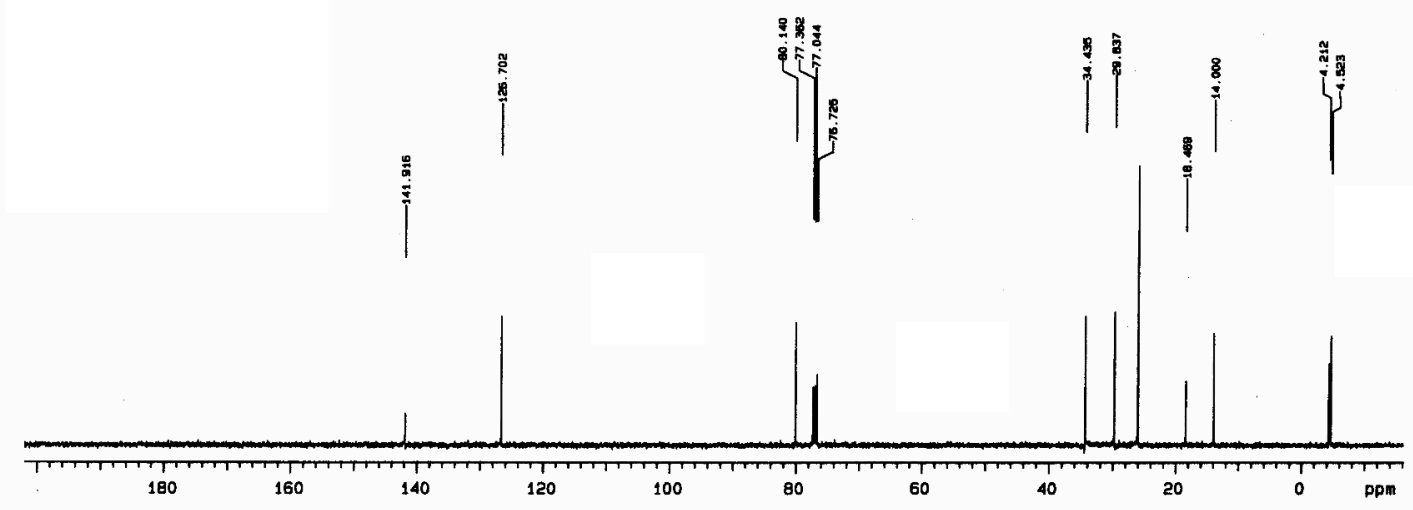

${ }^{1} \mathrm{H}$ and ${ }^{13} \mathrm{C}$ NMR spectra of $5\left(\mathrm{CDCl}_{3}\right)$ 

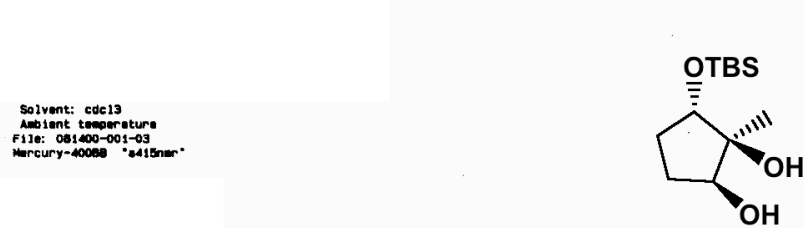

Fine: $0814000-001-03$

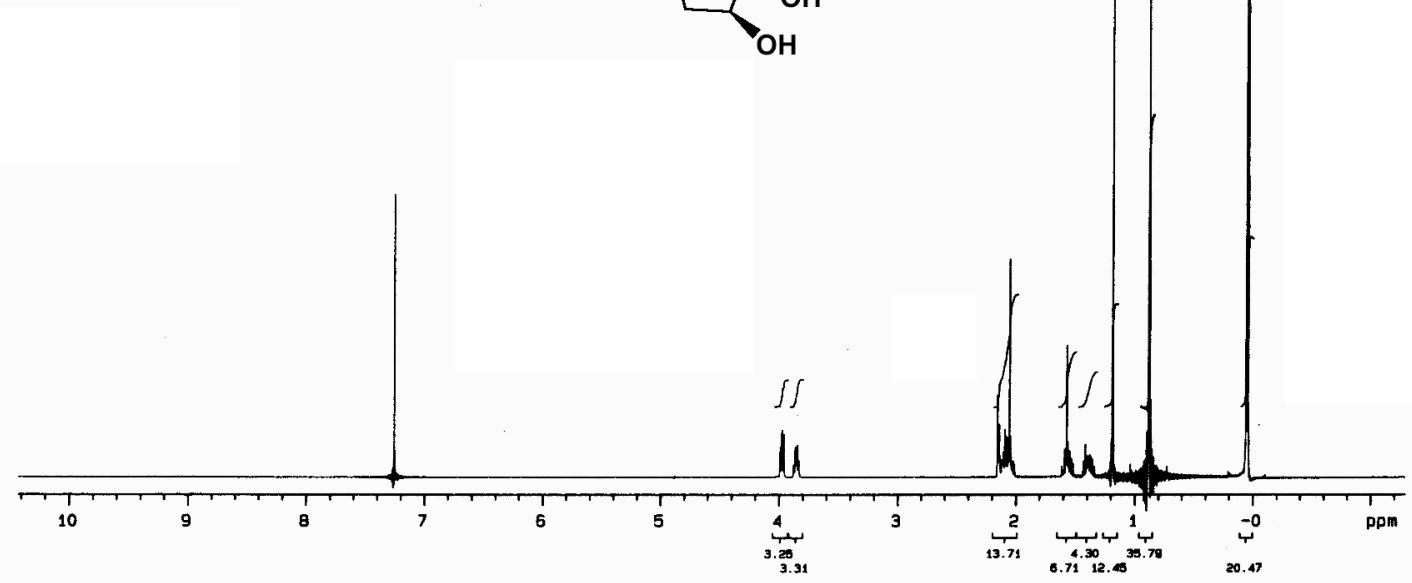

selvent: coests
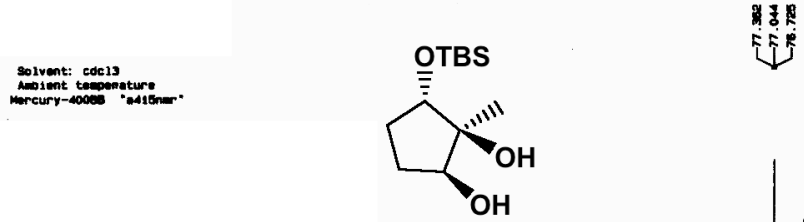

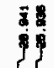

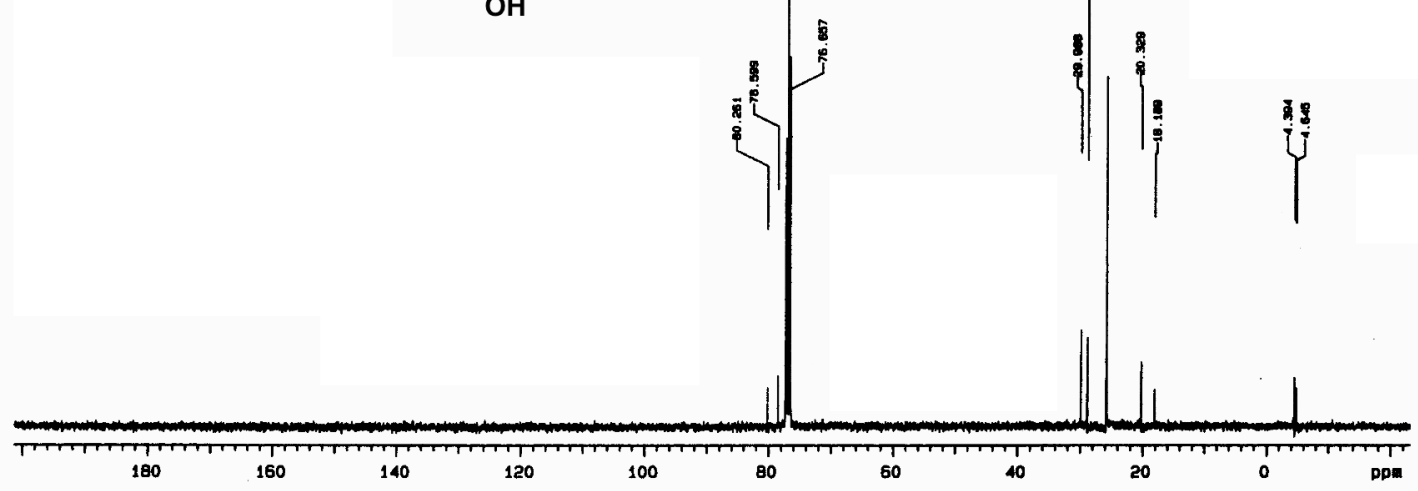

${ }^{1} \mathrm{H}$ and ${ }^{13} \mathrm{C}$ NMR spectra of $6\left(\mathrm{CDCl}_{3}\right)$ 

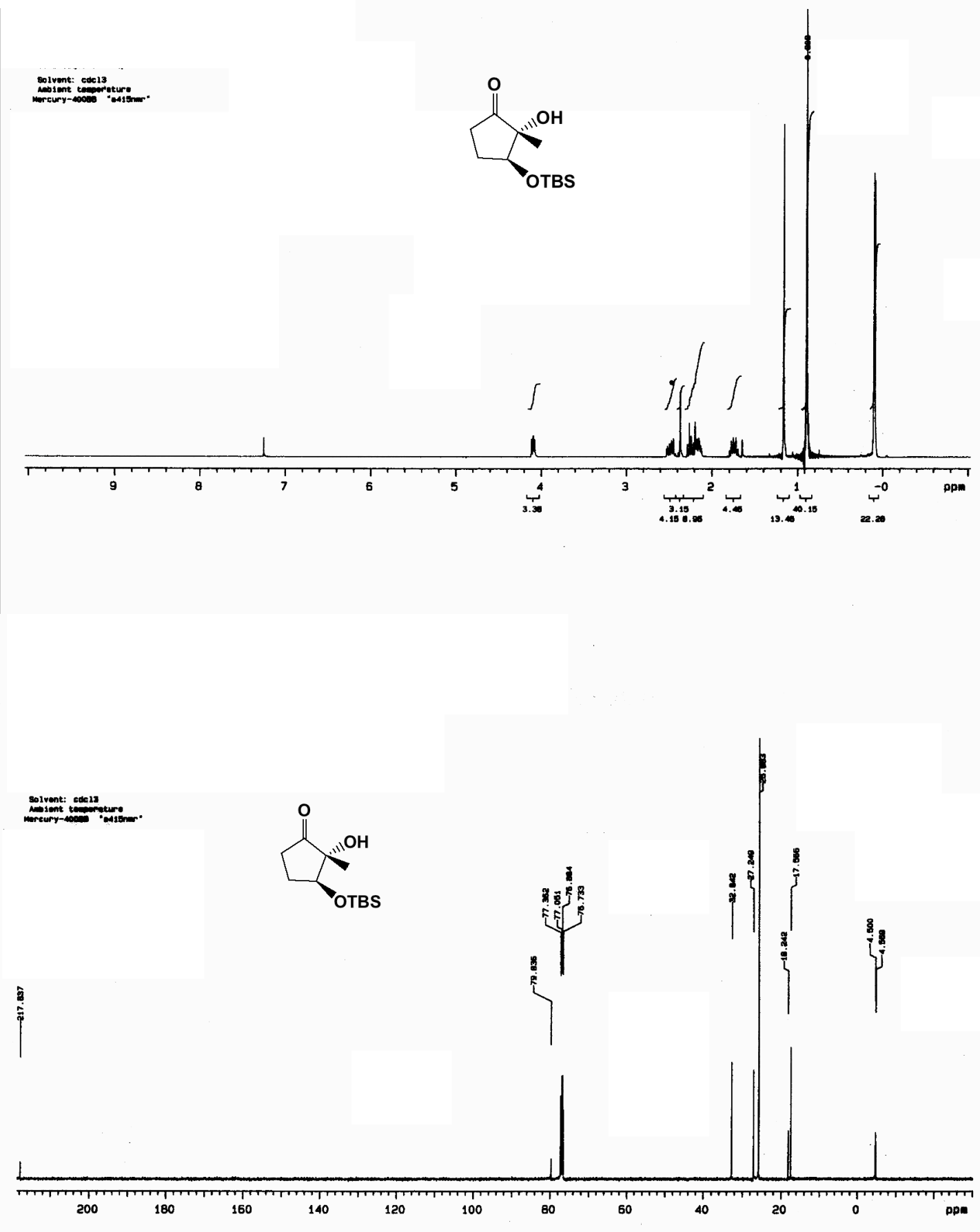

${ }^{1} \mathrm{H}$ and ${ }^{13} \mathrm{C}$ NMR spectra of $7\left(\mathrm{CDCl}_{3}\right)$ 

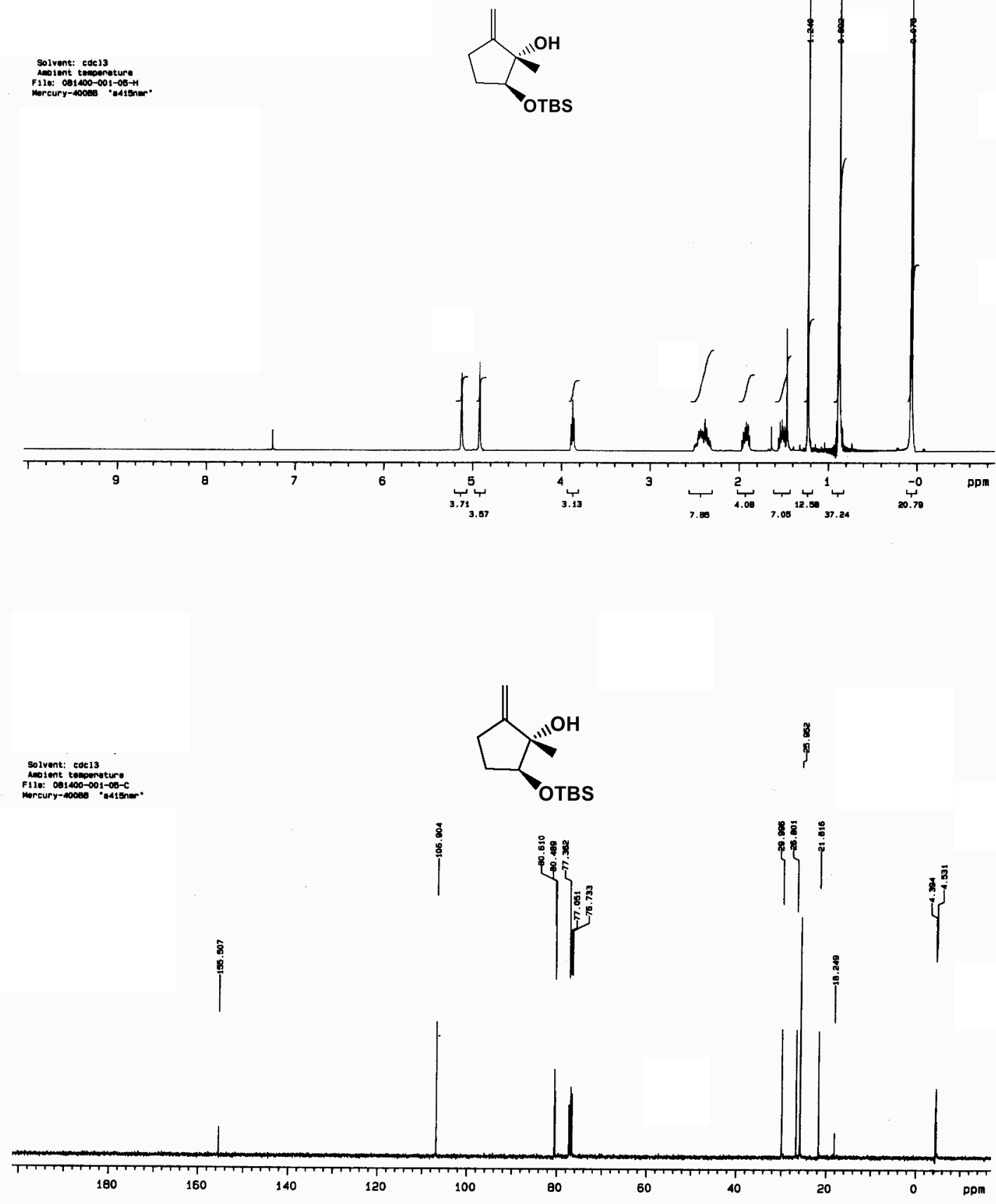

${ }^{1} \mathrm{H}$ and ${ }^{13} \mathrm{C}$ NMR spectra of $8\left(\mathrm{CDCl}_{3}\right)$ 

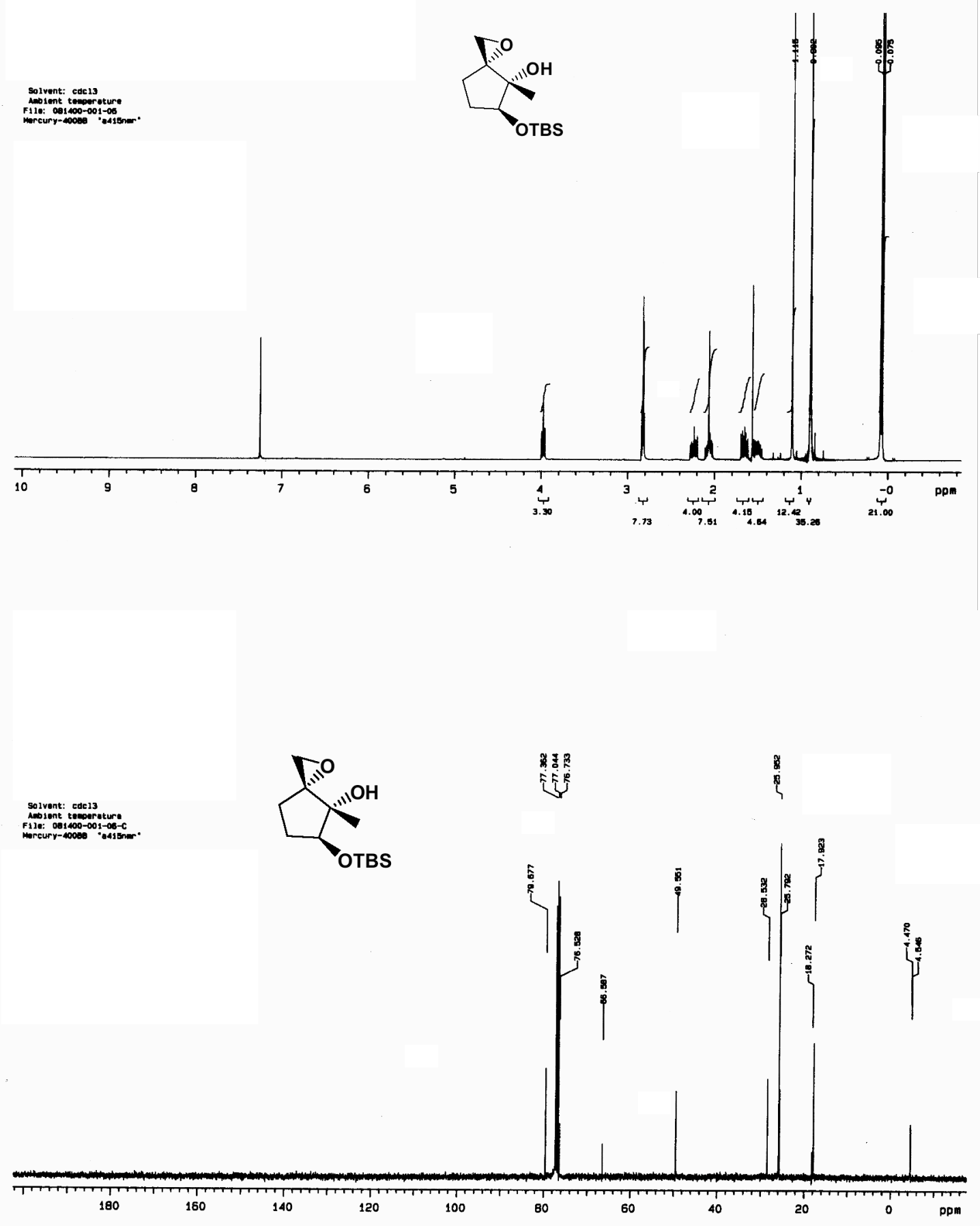

${ }^{1} \mathrm{H}$ and ${ }^{13} \mathrm{C}$ NMR spectra of $9\left(\mathrm{CDCl}_{3}\right)$ 


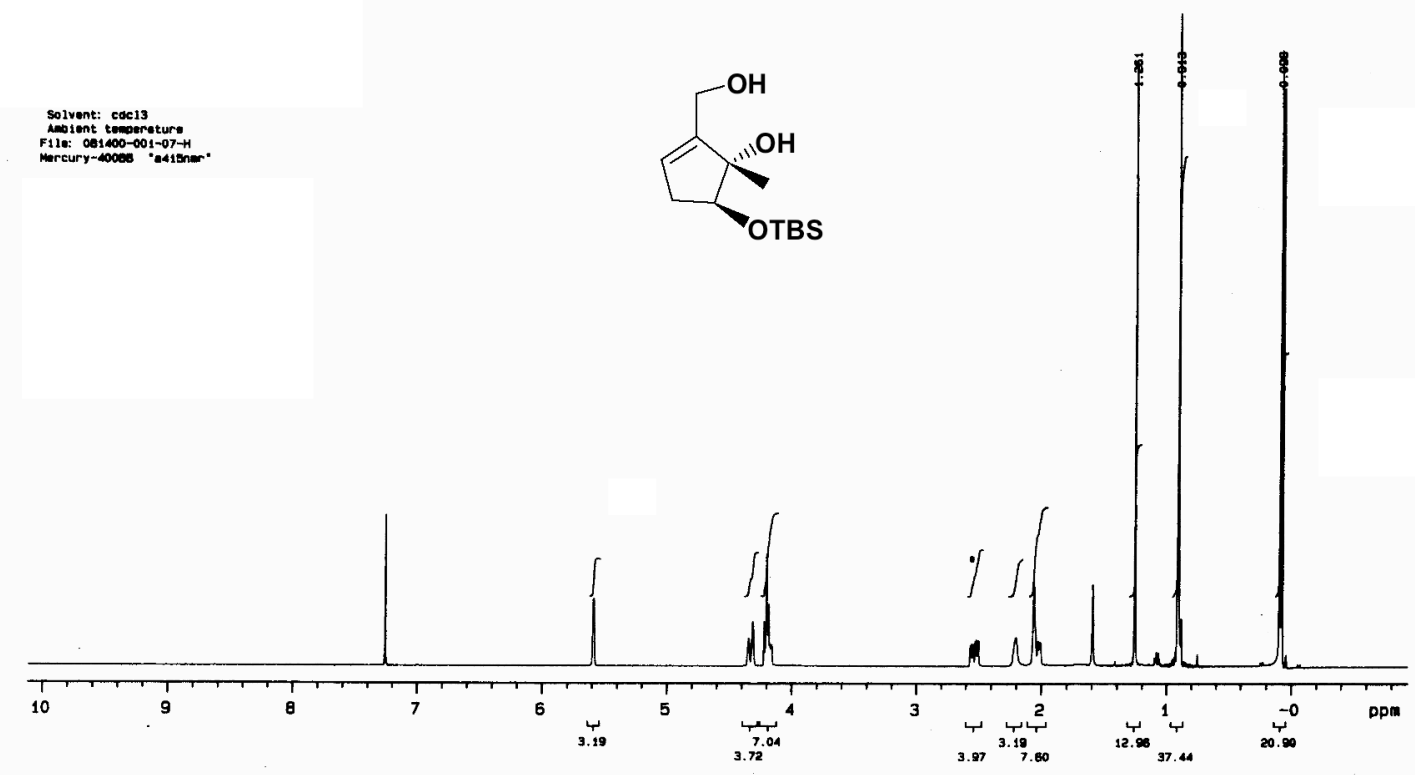

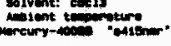
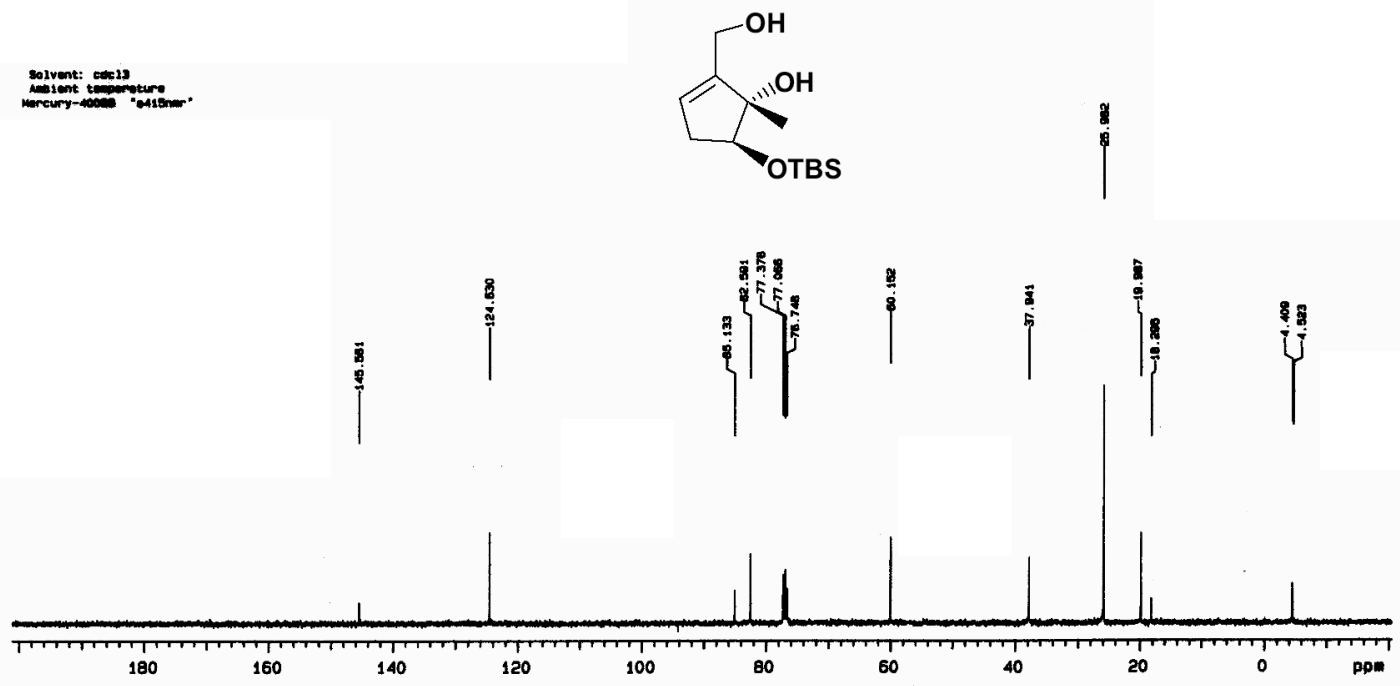

${ }^{1} \mathrm{H}$ and ${ }^{13} \mathrm{C}$ NMR spectra of $\mathbf{1 0}\left(\mathrm{CDCl}_{3}\right)$ 

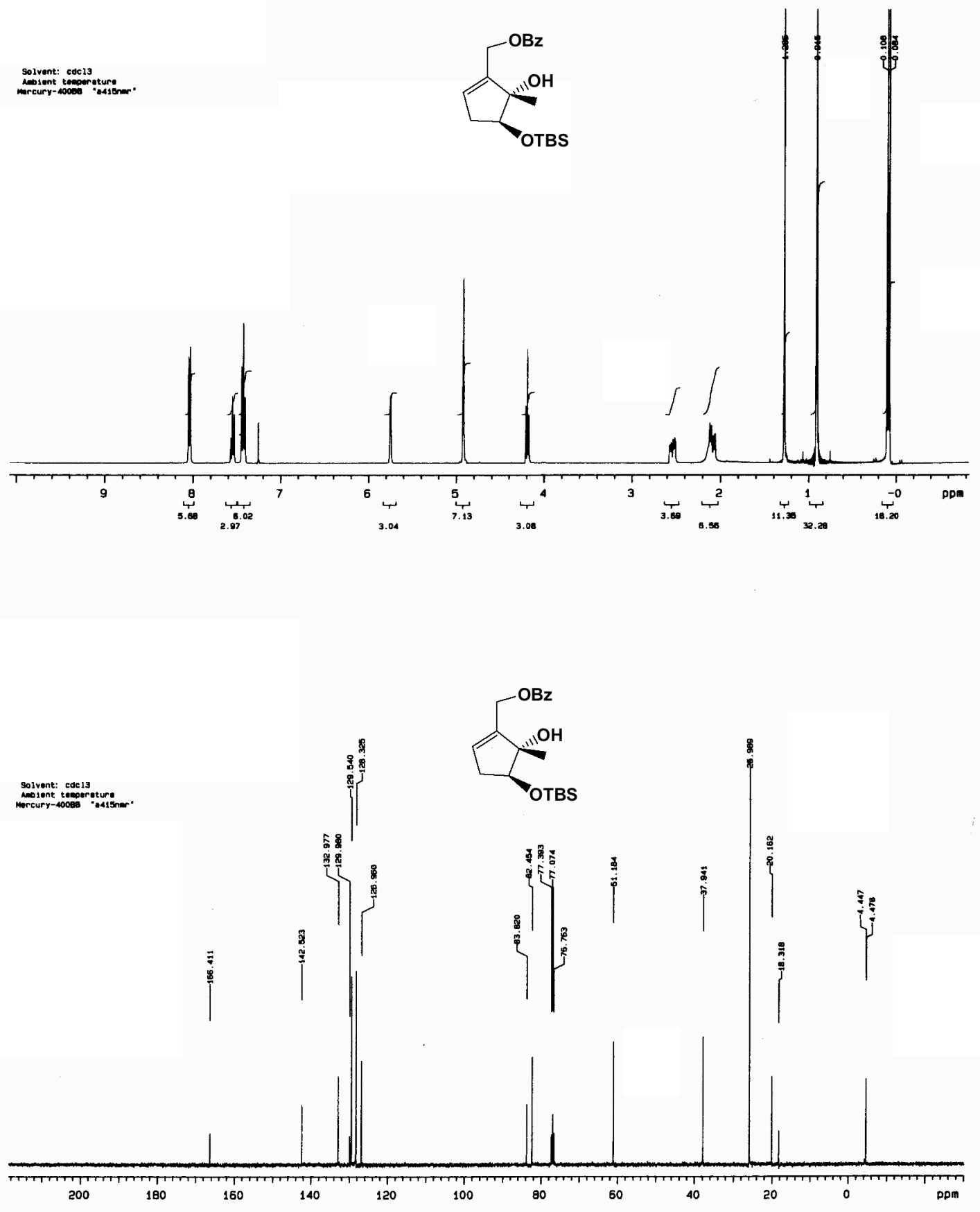

${ }^{1} \mathrm{H}$ and ${ }^{13} \mathrm{C}$ NMR spectra of $\mathbf{1 1}\left(\mathrm{CDCl}_{3}\right)$ 

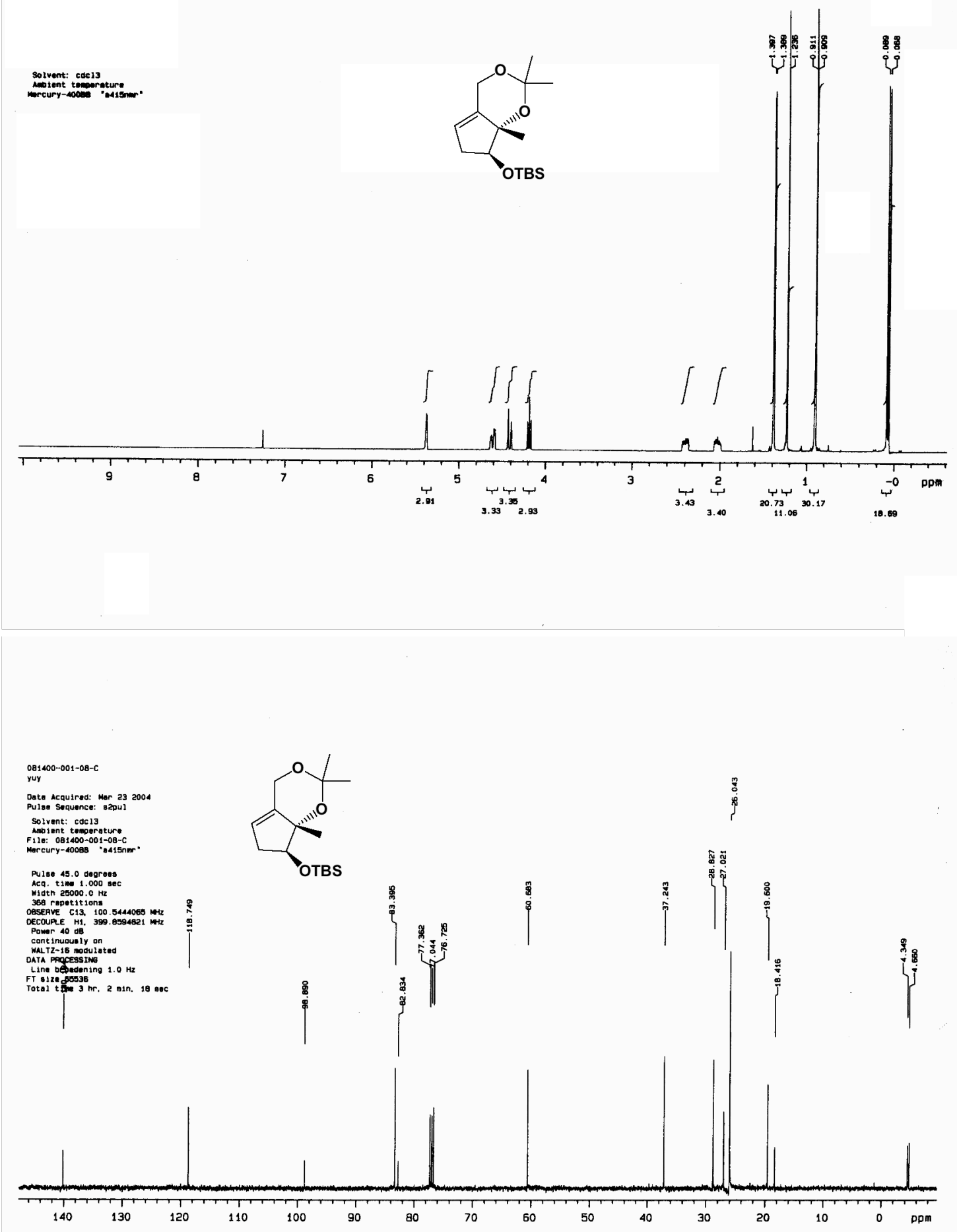

${ }^{1} \mathrm{H}$ and ${ }^{13} \mathrm{C}$ NMR spectra of the listed compound $\left(\mathrm{CDCl}_{3}\right)$ 

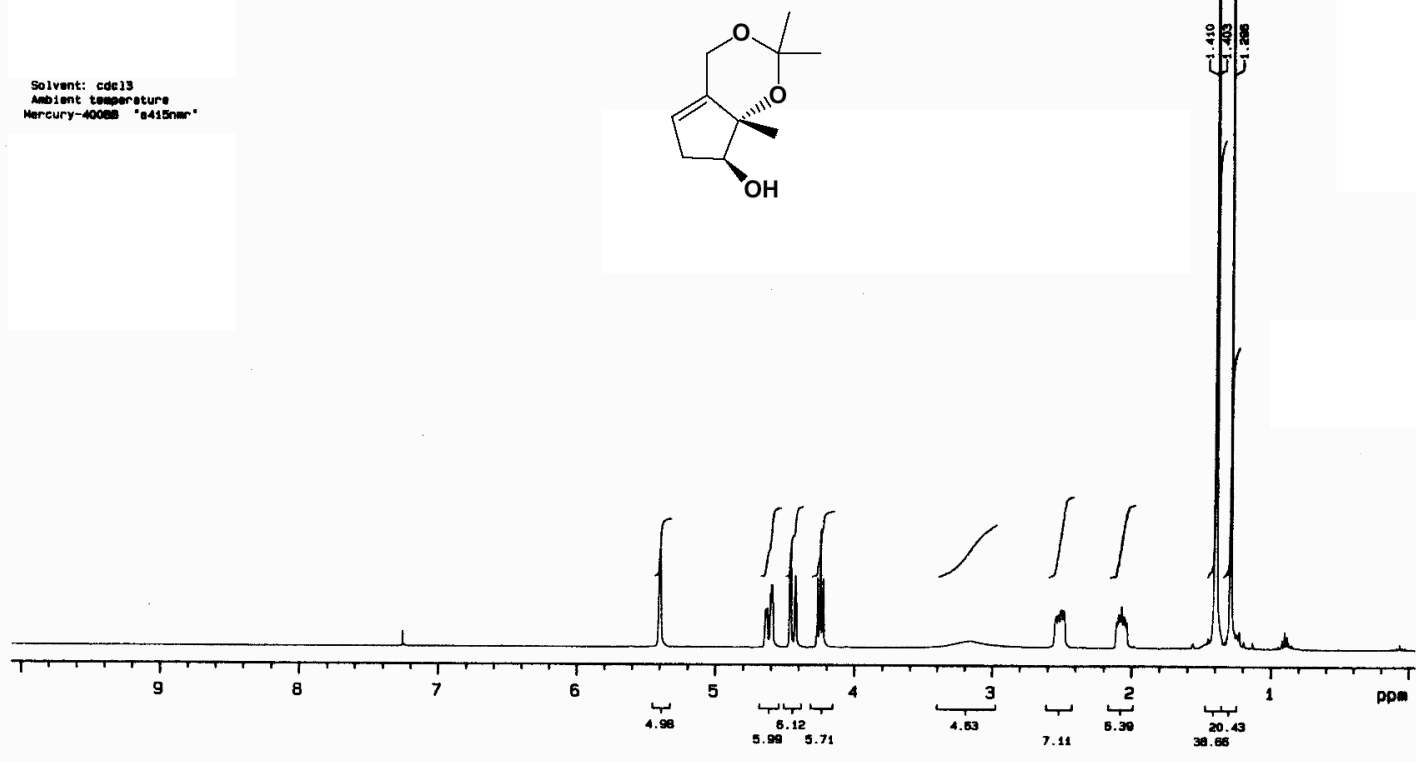

Solvent: cate13

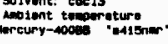
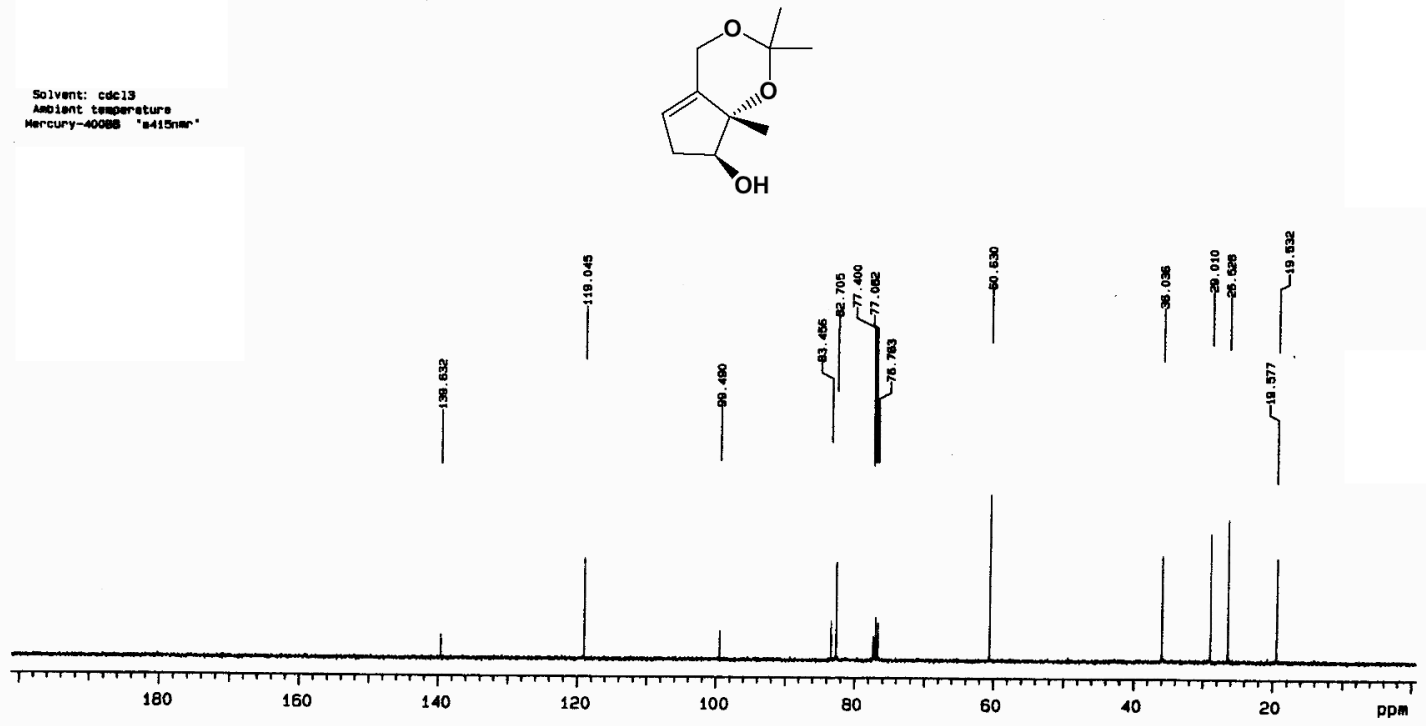

${ }^{1} \mathrm{H}$ and ${ }^{13} \mathrm{C}$ NMR spectra of the listed compound $\left(\mathrm{CDCl}_{3}\right)$ 

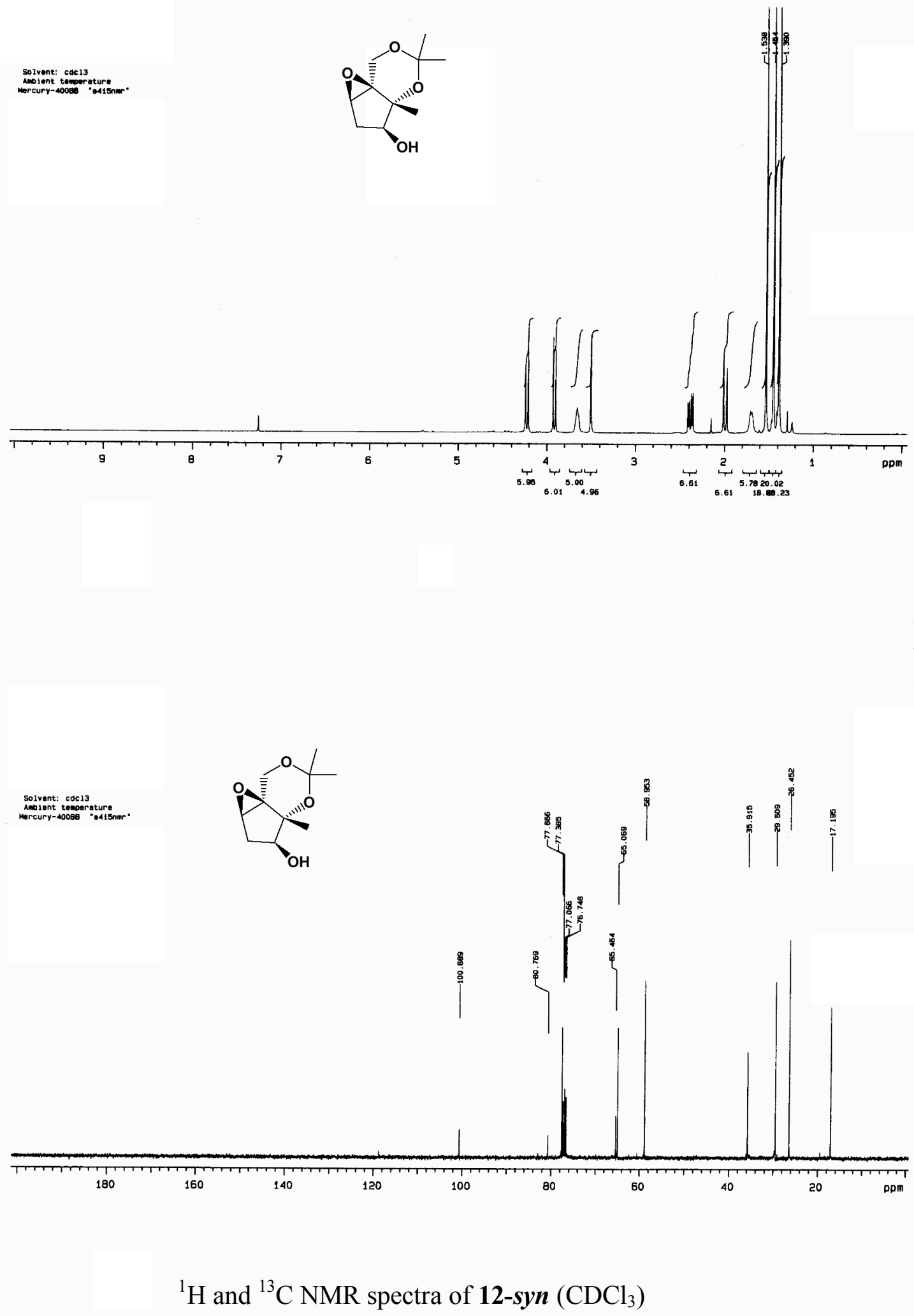

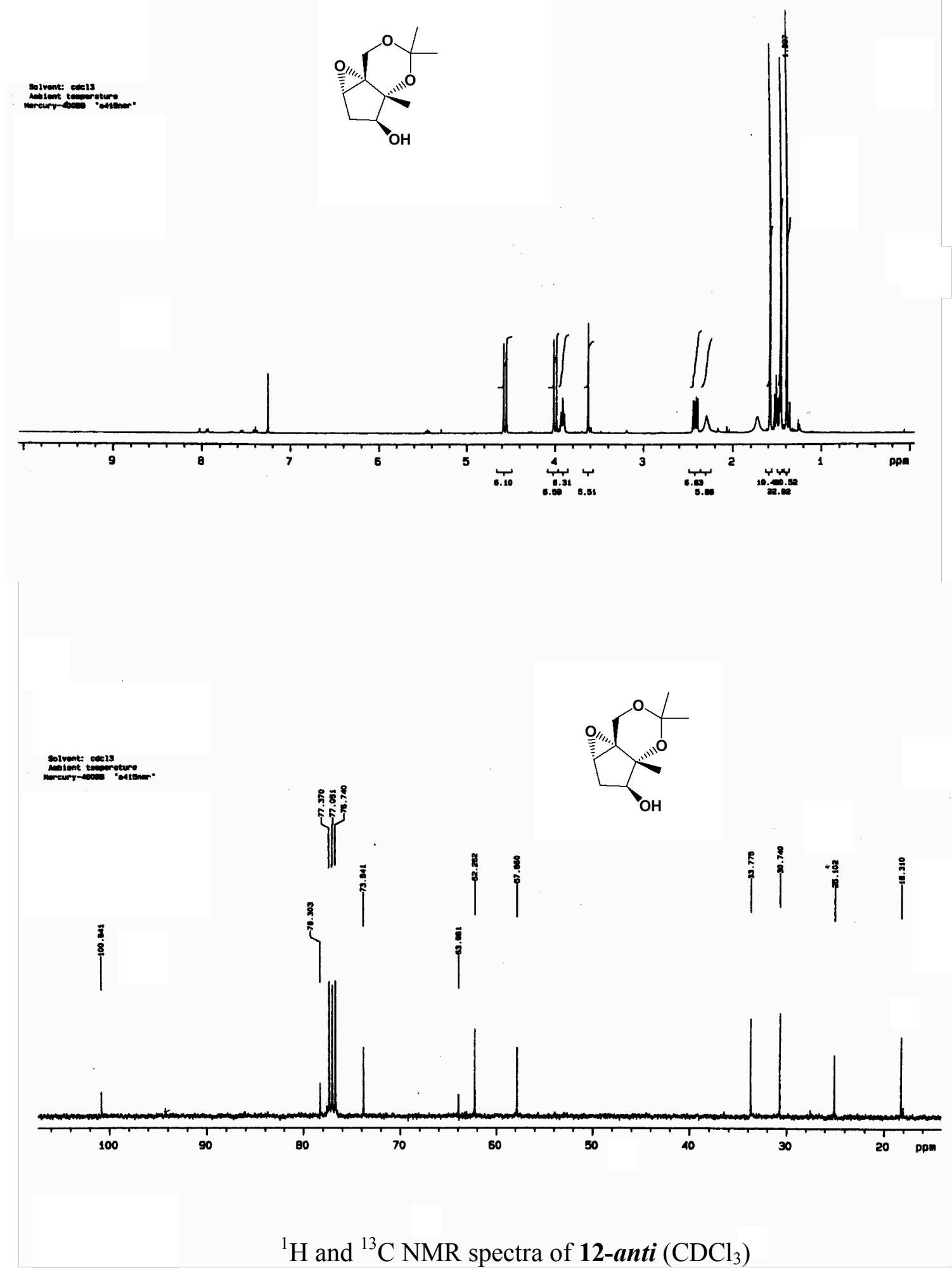

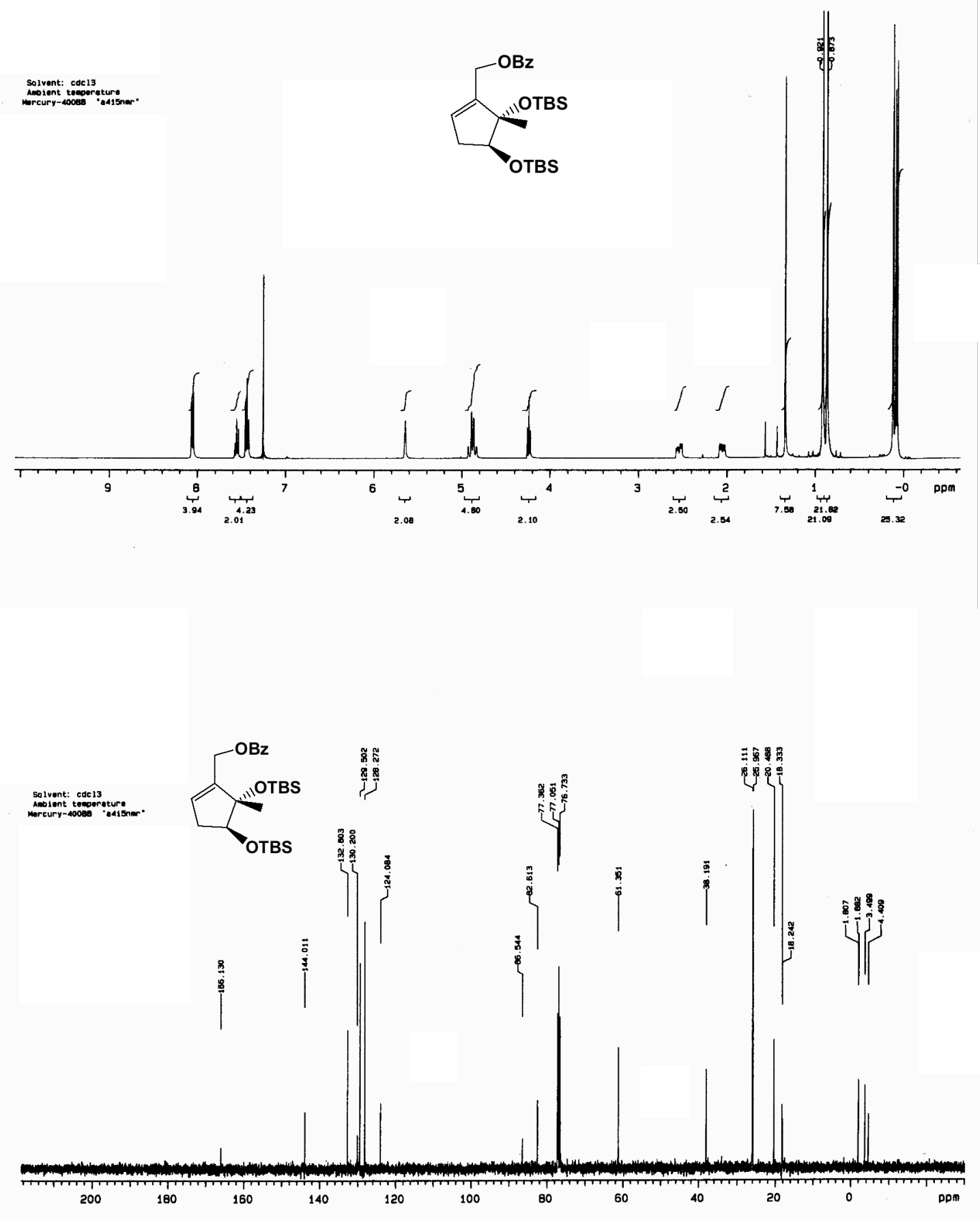

\footnotetext{
${ }^{1} \mathrm{H}$ and ${ }^{13} \mathrm{C}$ NMR spectra of $\mathbf{1 3}\left(\mathrm{CDCl}_{3}\right)$
} 

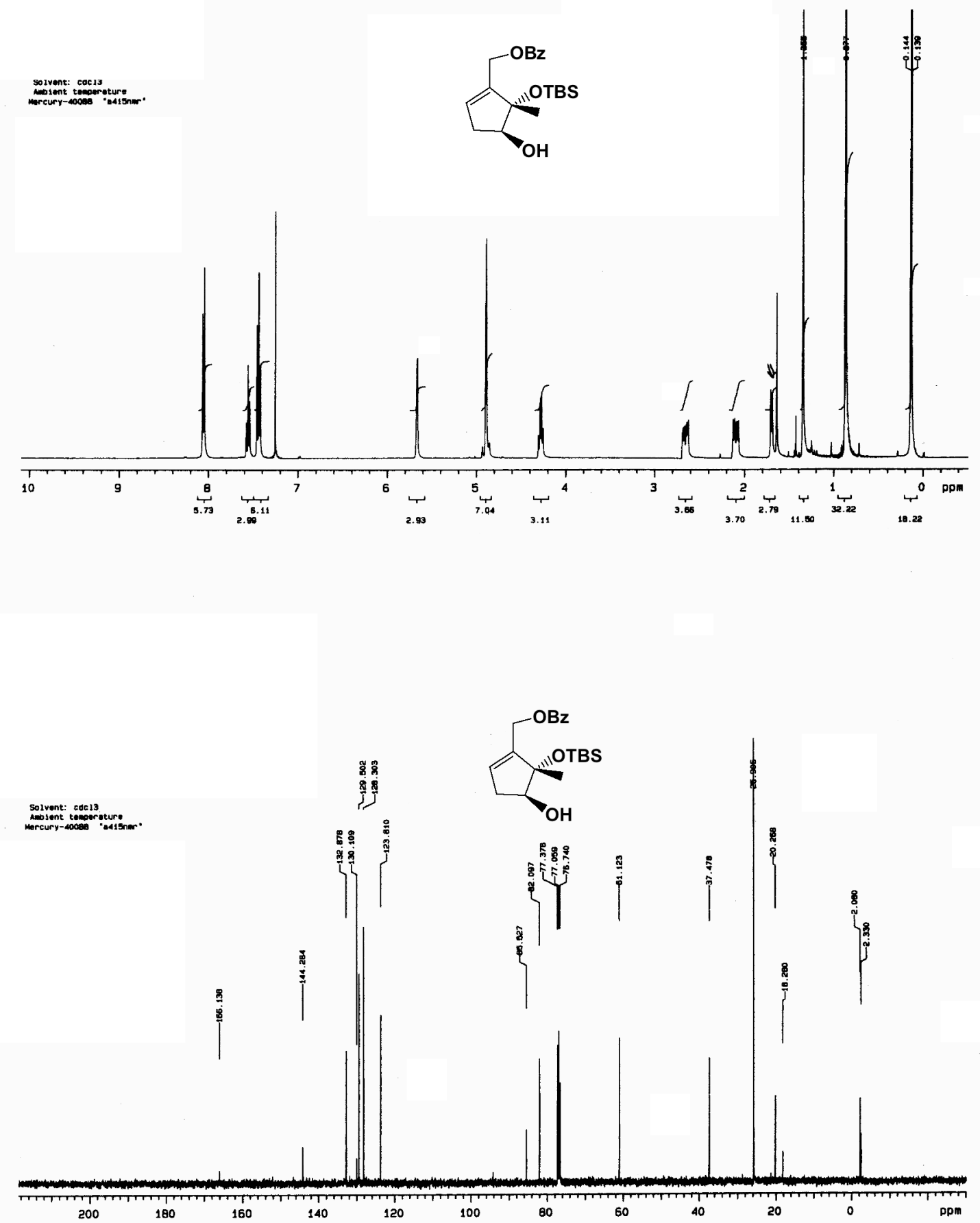

${ }^{1} \mathrm{H}$ and ${ }^{13} \mathrm{C}$ NMR spectra of $\mathbf{1 4}\left(\mathrm{CDCl}_{3}\right)$ 

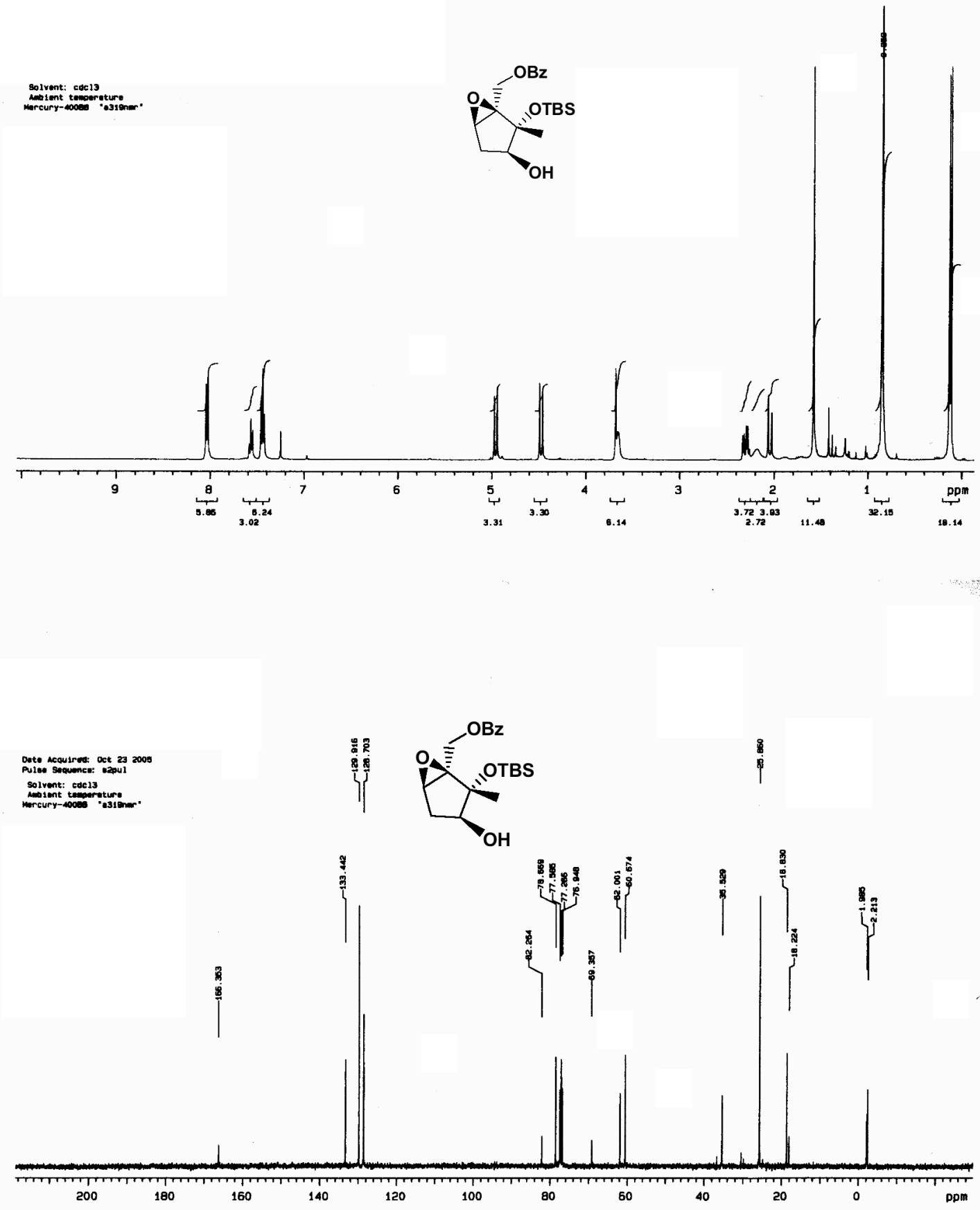

${ }^{1} \mathrm{H}$ and ${ }^{13} \mathrm{C}$ NMR spectra of $\mathbf{1 5}$-syn $\left(\mathrm{CDCl}_{3}\right)$ 
solvent: cocis
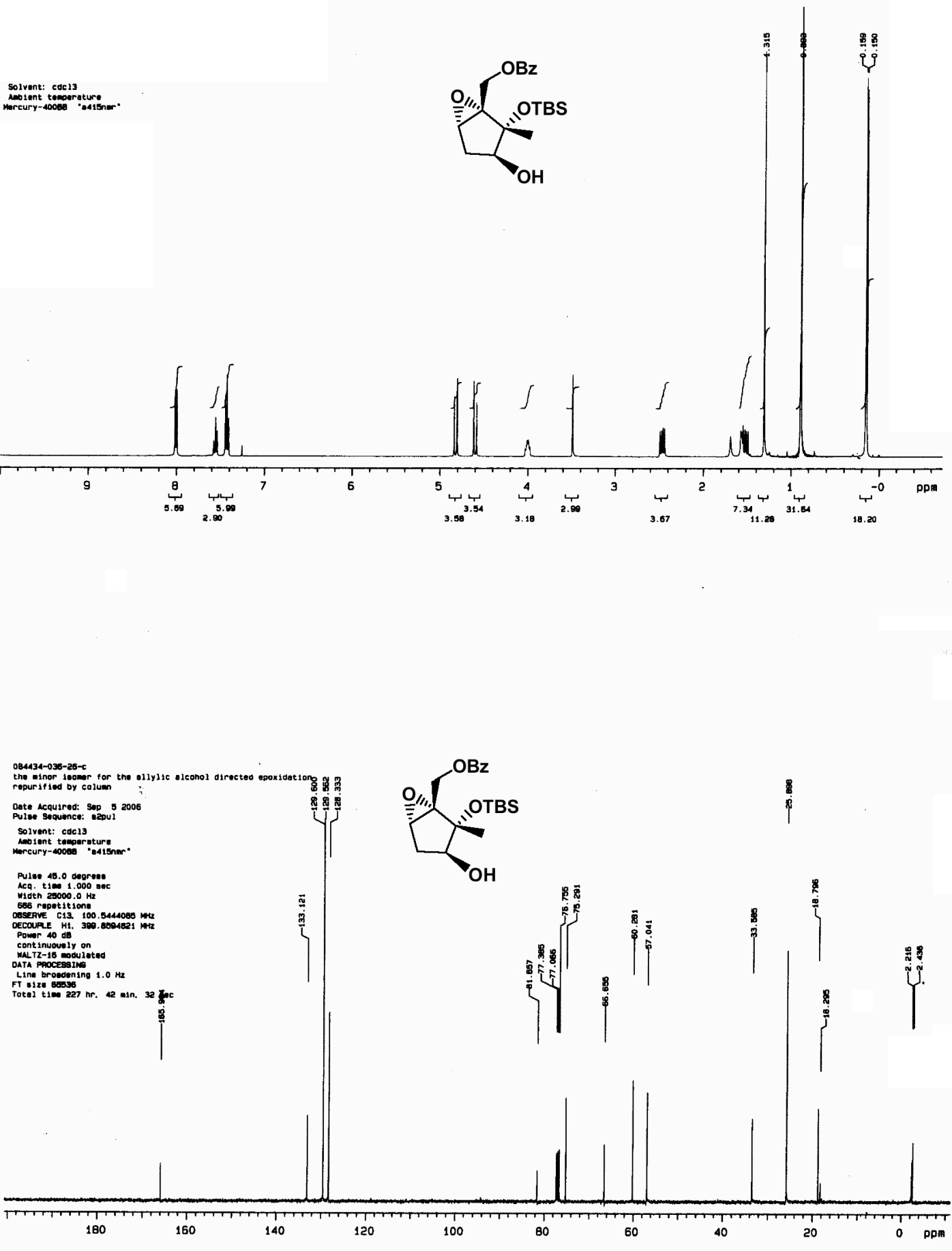

${ }^{1} \mathrm{H}$ and ${ }^{13} \mathrm{C}$ NMR spectra of $\mathbf{1 5}$-anti $\left(\mathrm{CDCl}_{3}\right)$ 

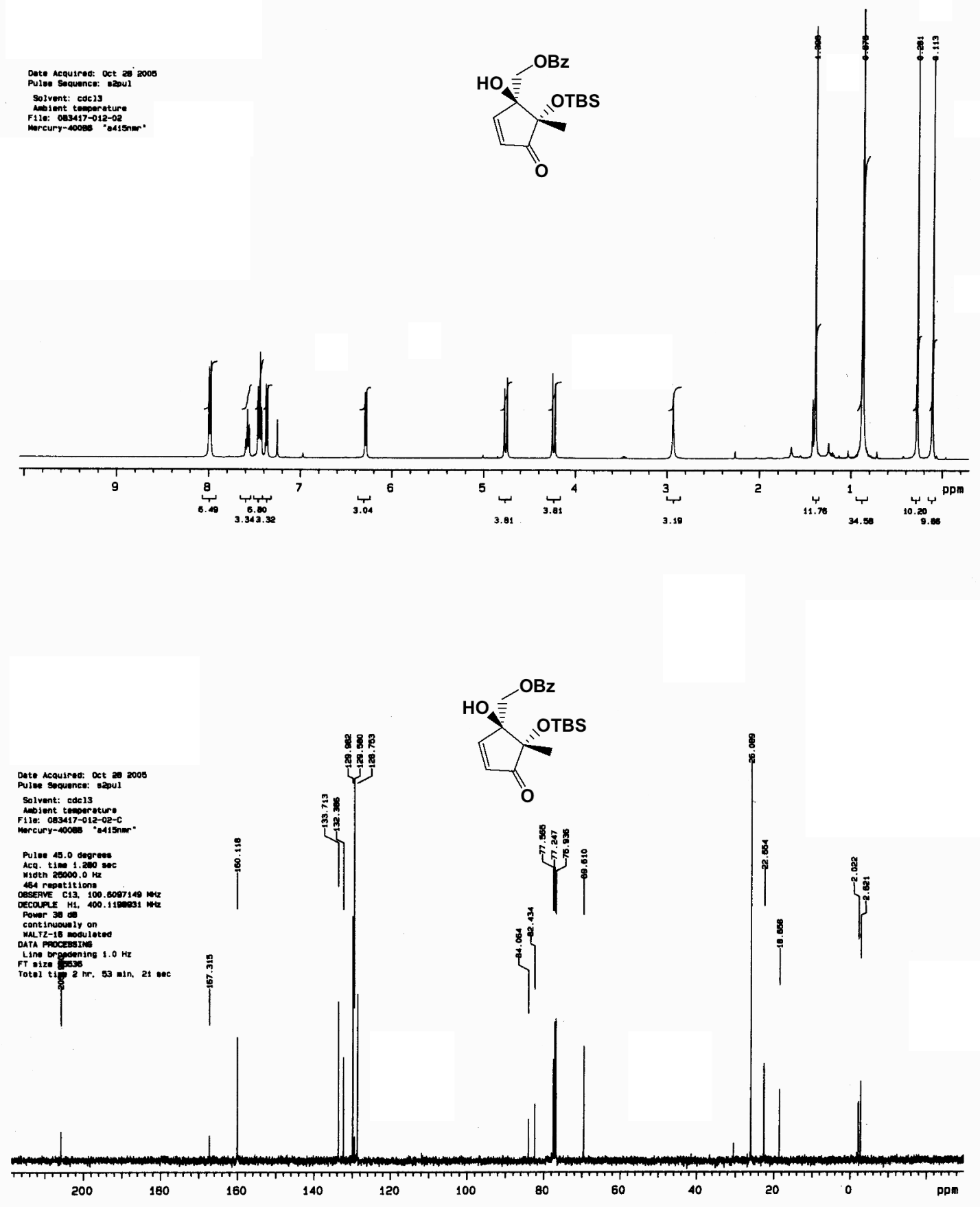

${ }^{1} \mathrm{H}$ and ${ }^{13} \mathrm{C}$ NMR spectra of $\mathbf{1 6}\left(\mathrm{CDCl}_{3}\right)$ 


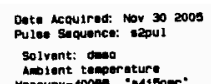

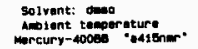
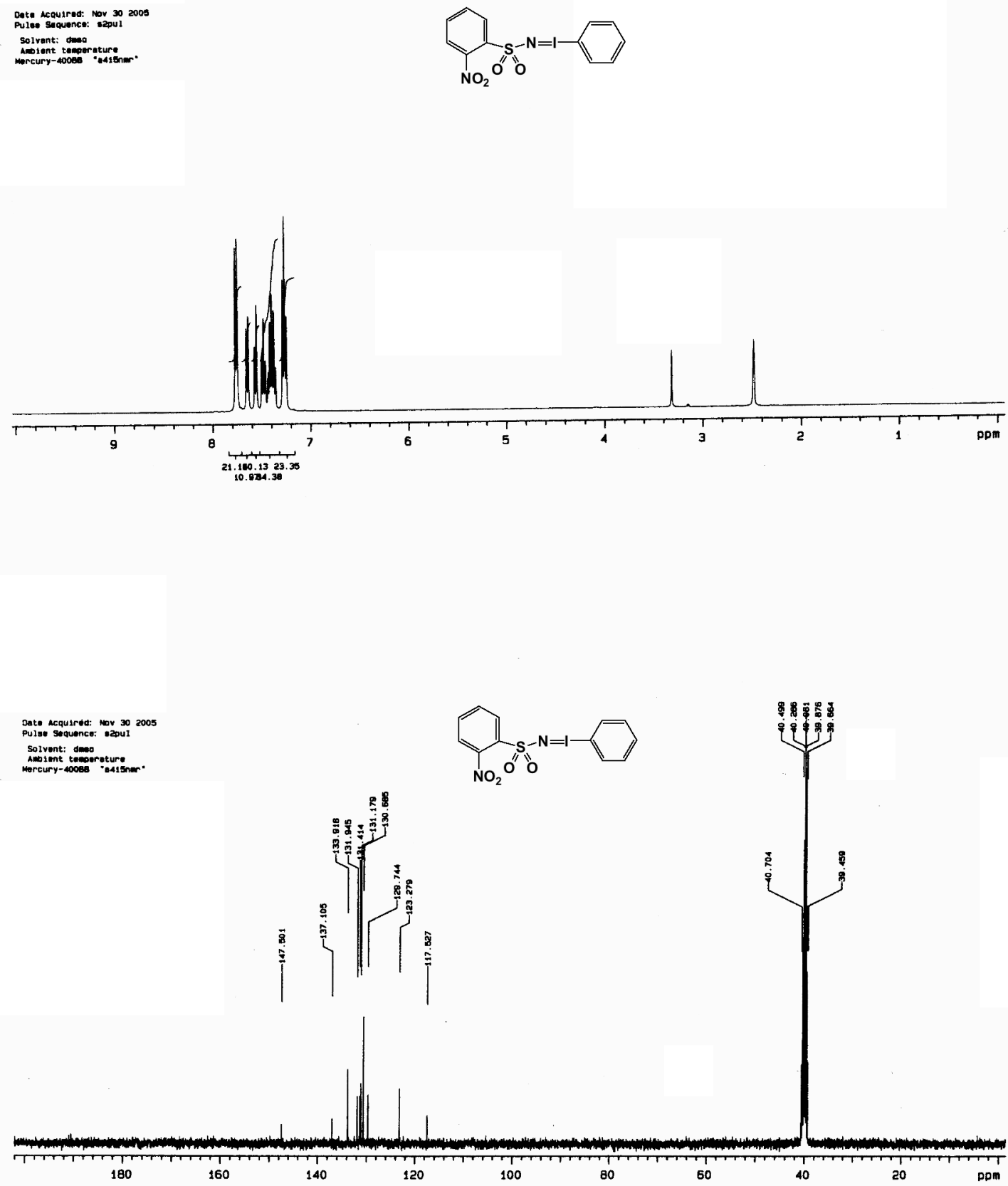

${ }^{1} \mathrm{H}$ and ${ }^{13} \mathrm{C}$ NMR spectra of $[\mathrm{N}-(2-$ nitrophenylsulfonyl)imino]phenyliodinane (DMSO- $d_{6}$ ) 

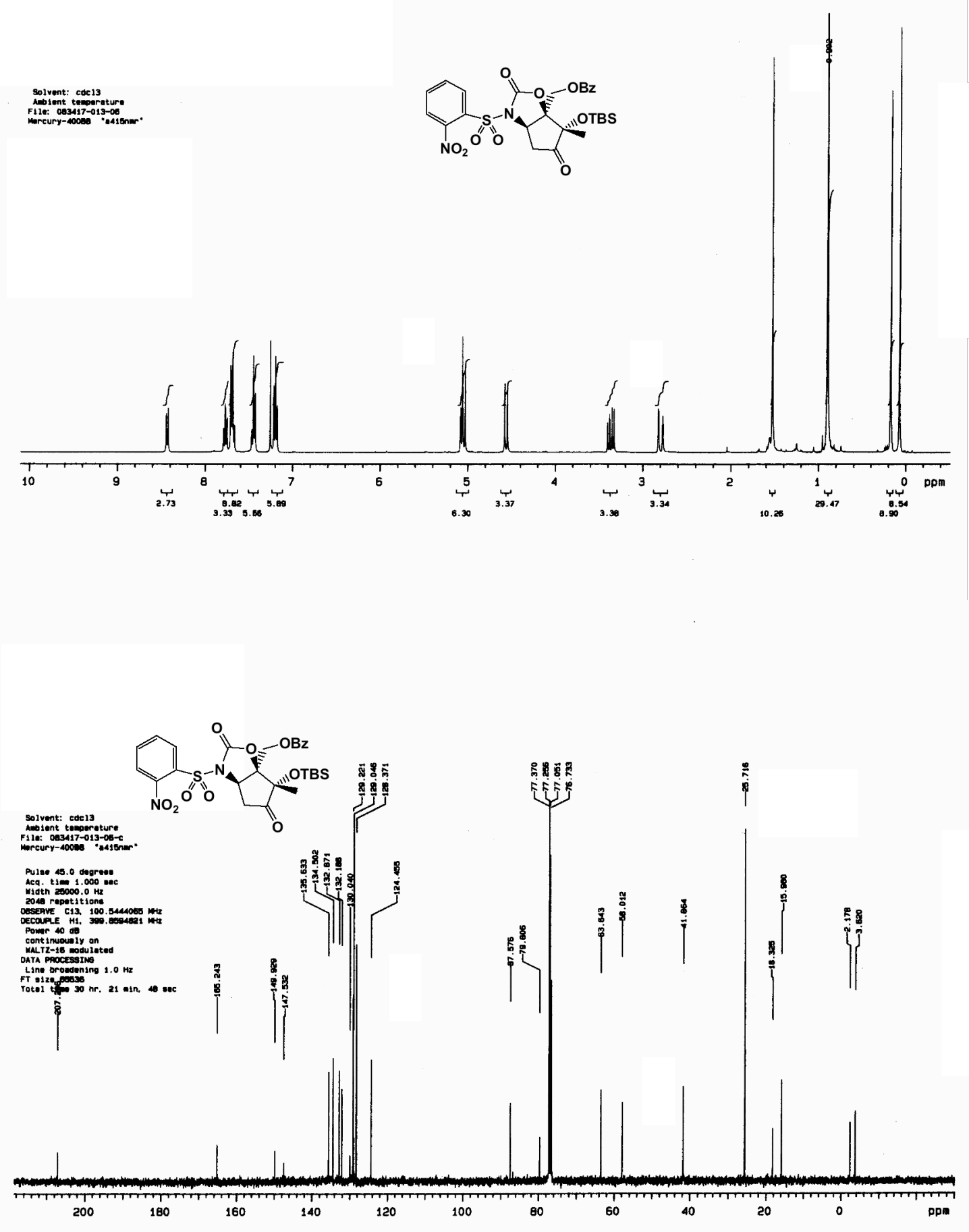

${ }^{1} \mathrm{H}$ and ${ }^{13} \mathrm{C}$ NMR spectra of $\mathbf{1 7}\left(\mathrm{CDCl}_{3}\right)$ 

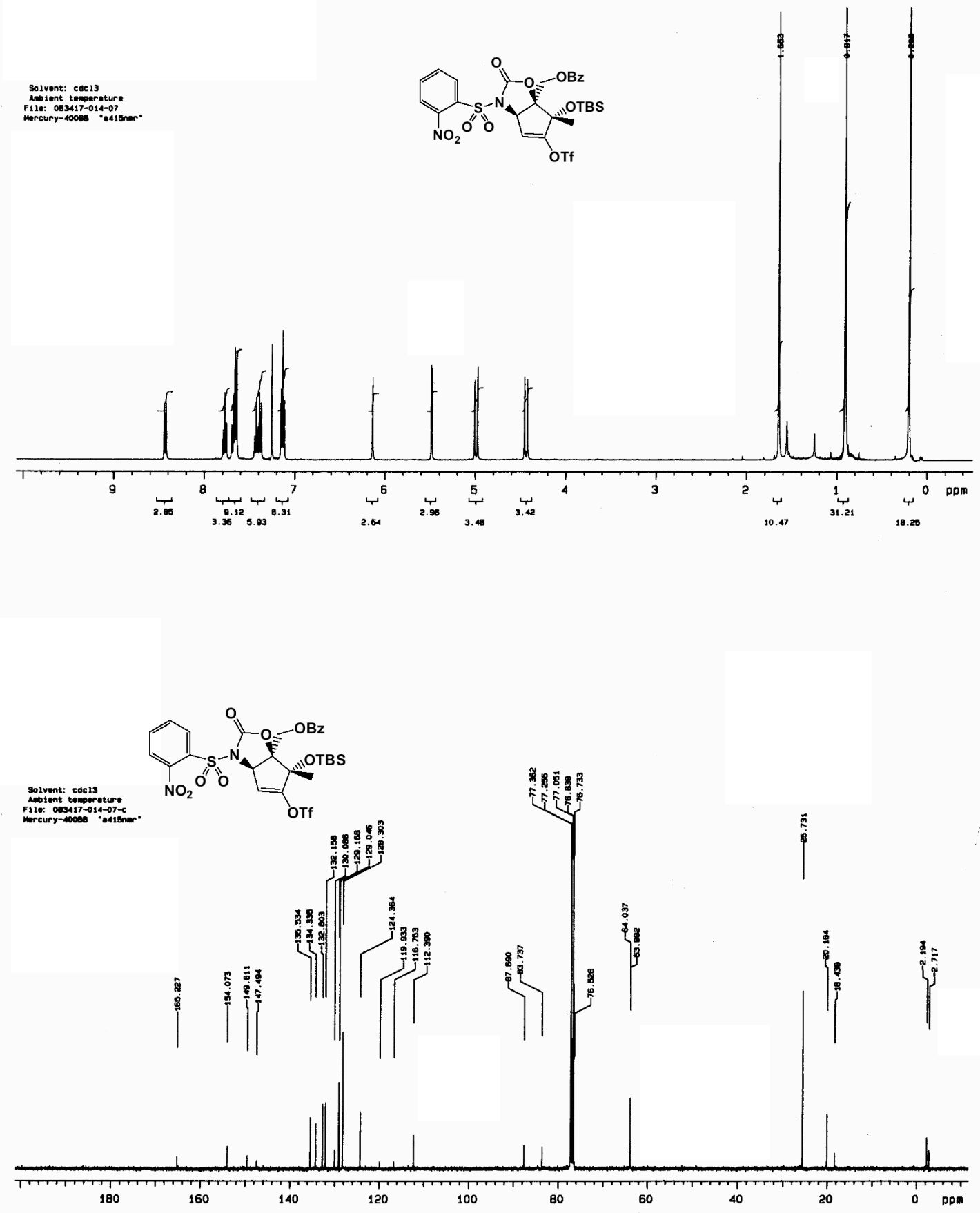

${ }^{1} \mathrm{H}$ and ${ }^{13} \mathrm{C}$ NMR spectra of $\mathbf{2 1}\left(\mathrm{CDCl}_{3}\right)$ 


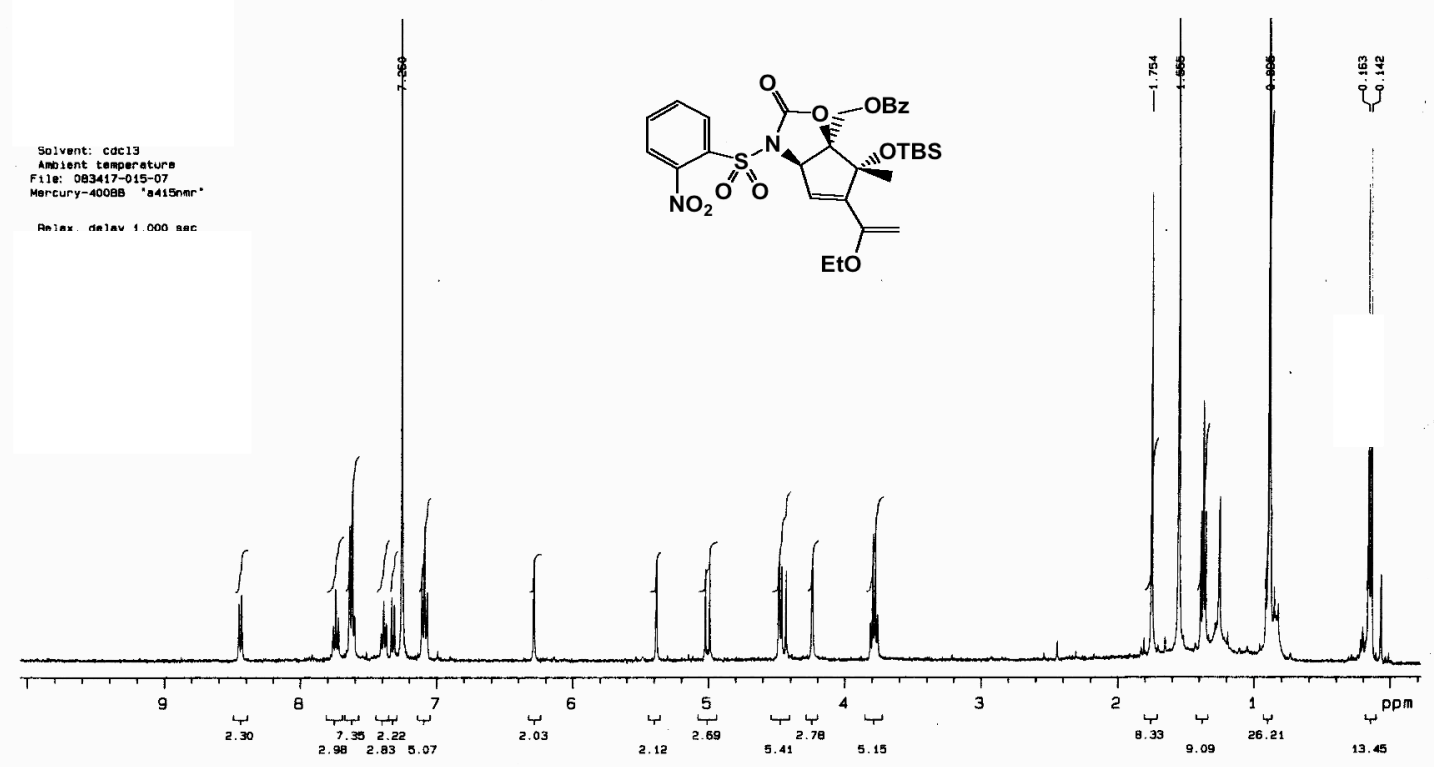

Solvent: codels
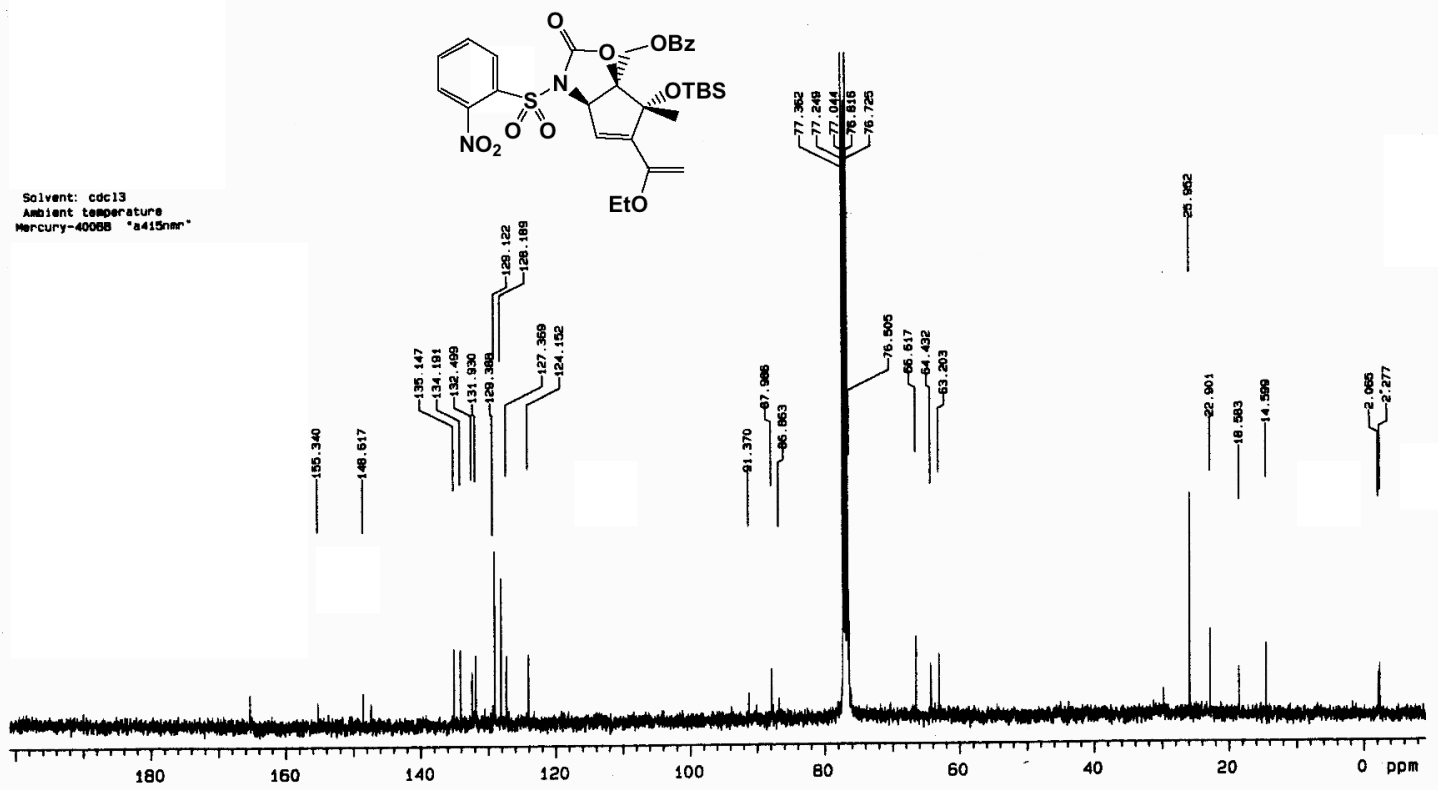

${ }^{1} \mathrm{H}$ and ${ }^{13} \mathrm{C}$ NMR spectra of $22\left(\mathrm{CDCl}_{3}\right)$ 

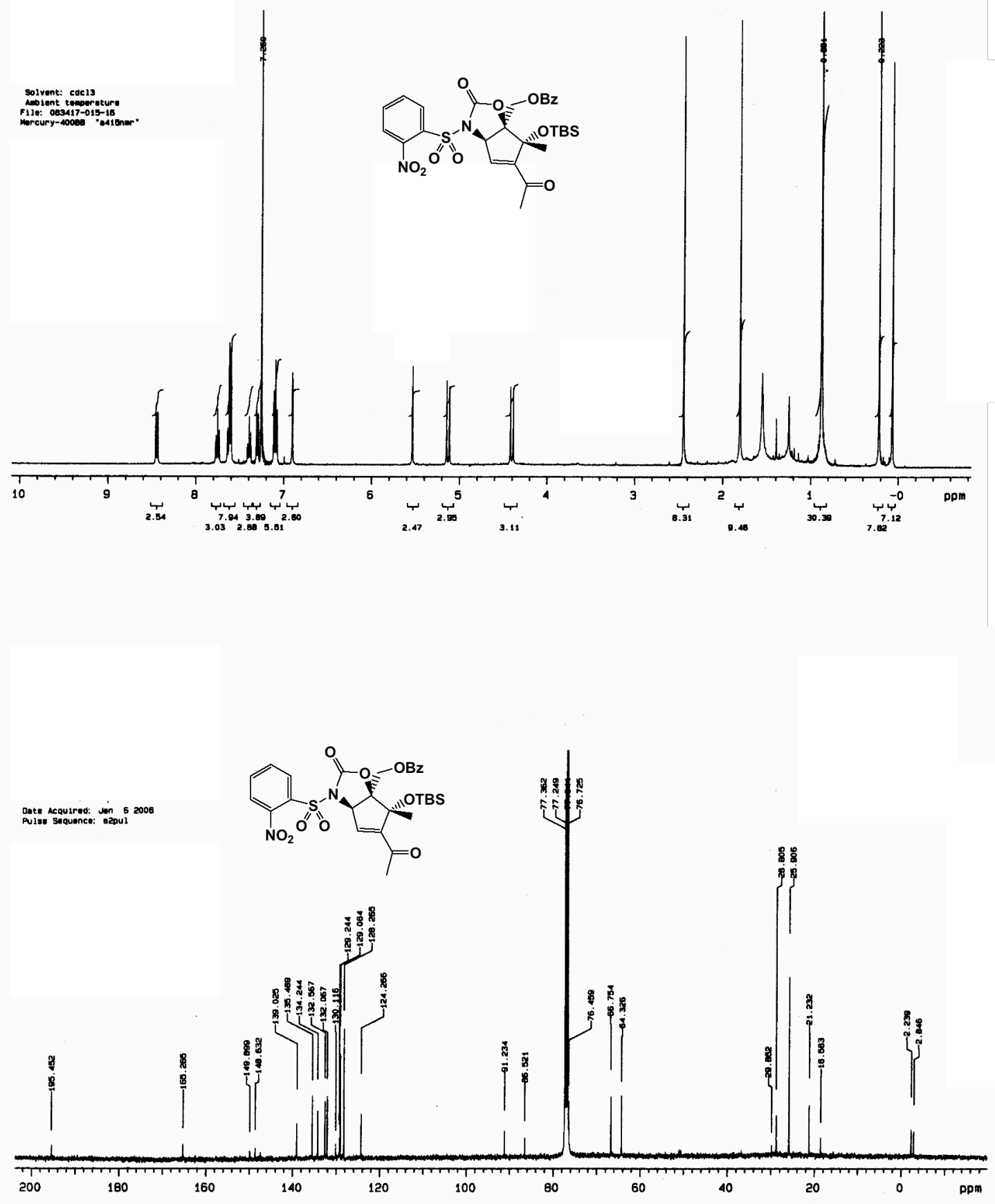

${ }^{1} \mathrm{H}$ and ${ }^{13} \mathrm{C}$ NMR spectra of $2\left(\mathrm{CDCl}_{3}\right)$ 

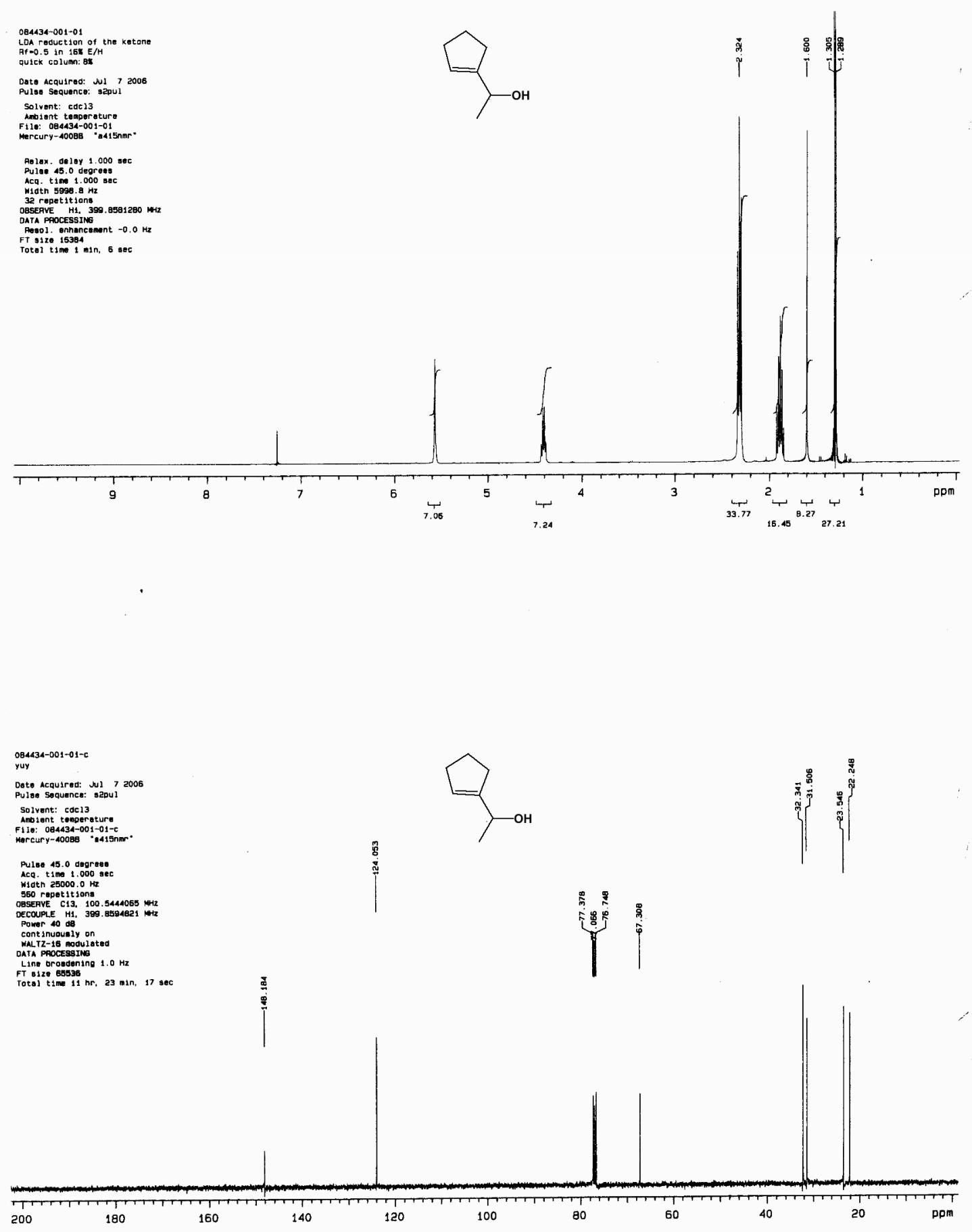

${ }^{1} \mathrm{H}$ and ${ }^{13} \mathrm{C}$ NMR spectra of 1-(1-hydroxyethyl)cyclopentene $\left(\mathrm{CDCl}_{3}\right)$ 

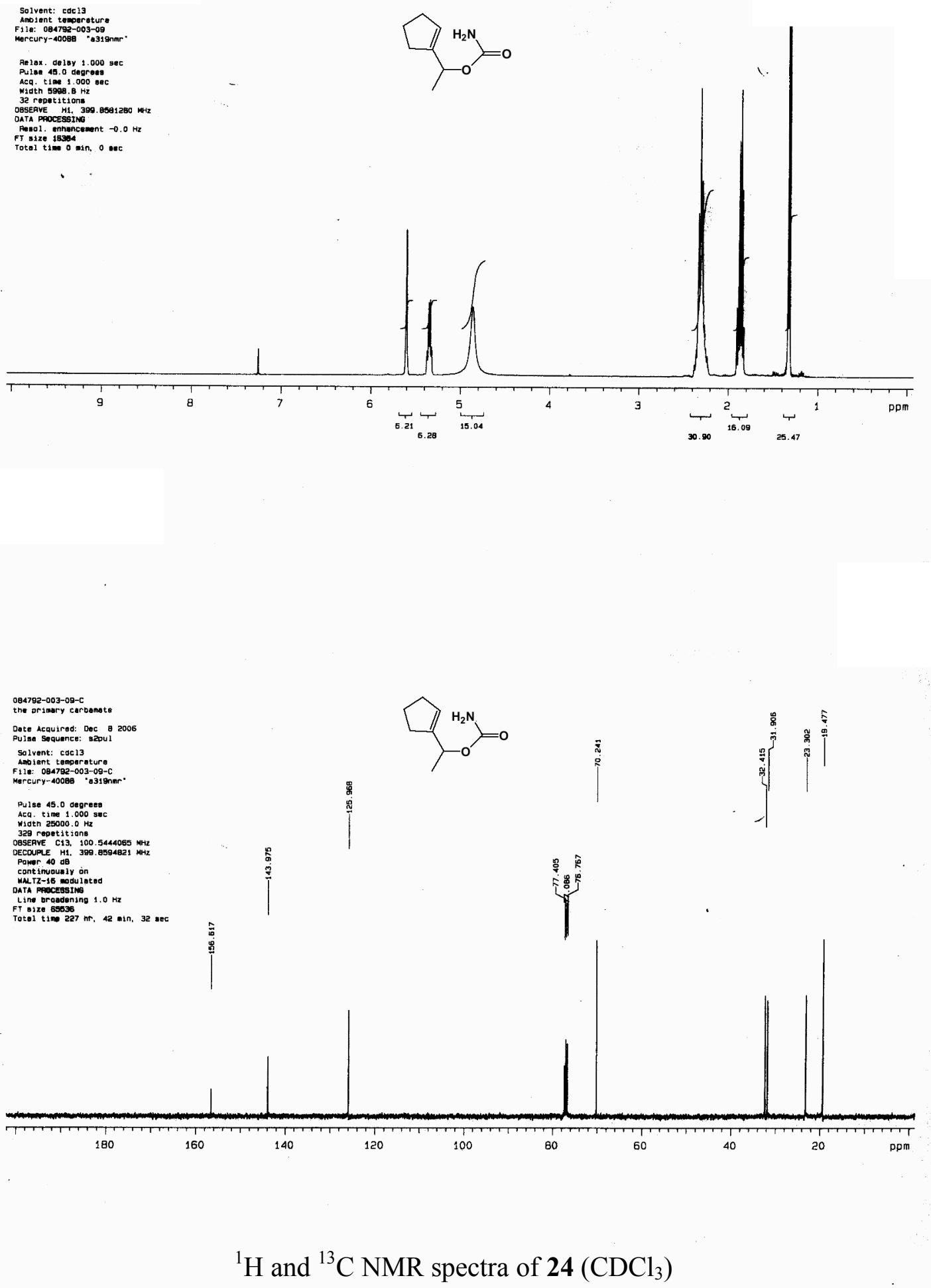
O64792-001-02

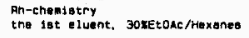

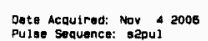

Solvent: : cdc13 13
Amo jent temperoture

F11:: $084792-001-02$
marcury-40088 "8318mm

Fe 18x. $0018 \mathrm{y} 1.000$ sec

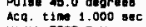

32 repot titians
OBSEVE H1. $399.8381280 \mathrm{HHz}$

OATA PROCESSIMG

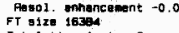

tota1 $\mathrm{t} 1 \mathrm{~m}=\mathrm{min}, 6 \mathrm{gec}$

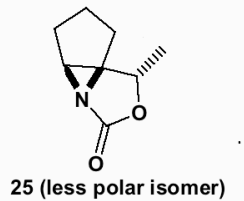

25 (less polar isomer)

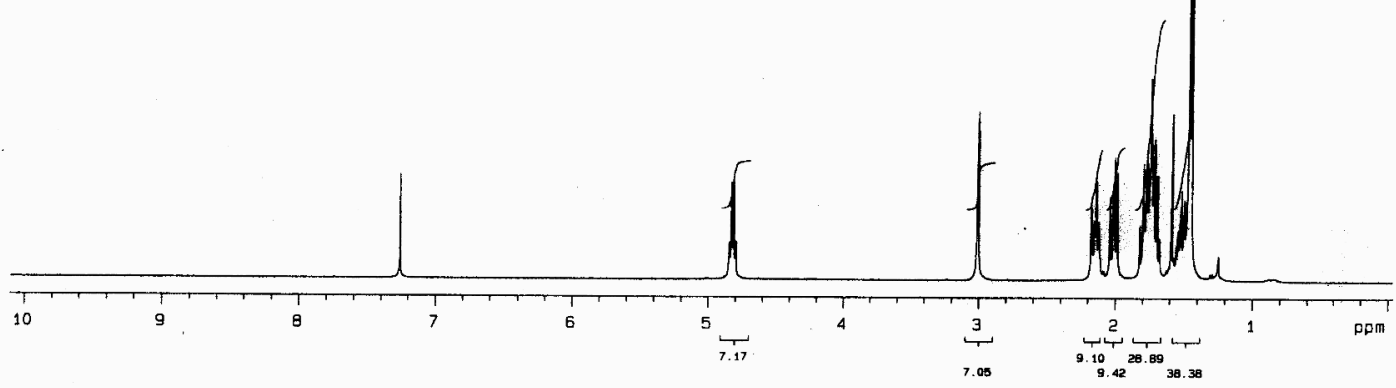

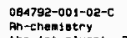

Tent, 30xEt OAC/Haxanas

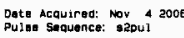

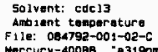

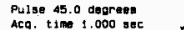

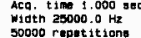

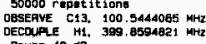

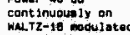

DATA PPOCESSING

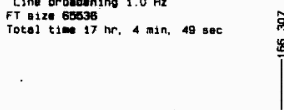

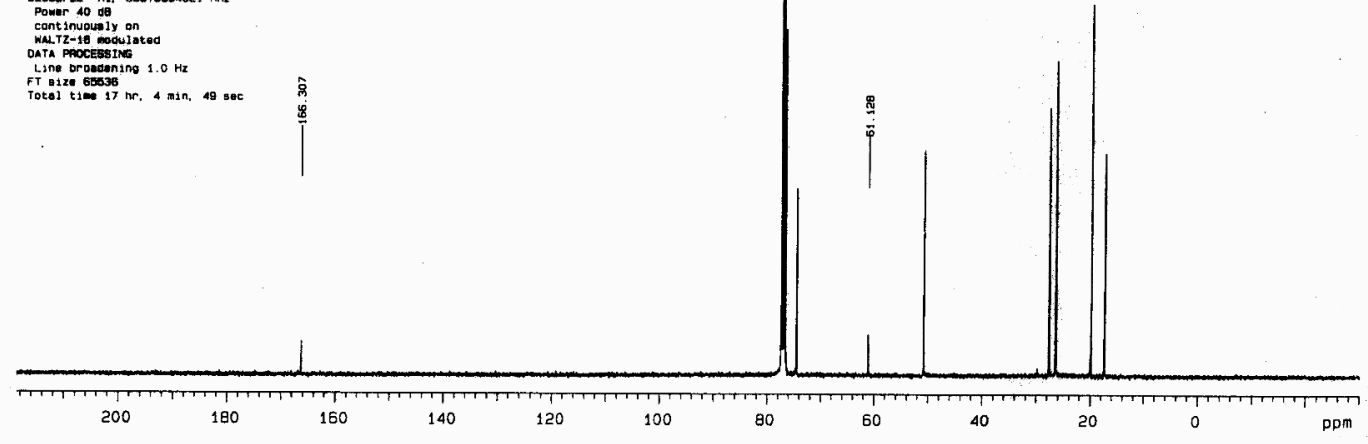

${ }^{1} \mathrm{H}$ and ${ }^{13} \mathrm{C}$ NMR spectra of $\mathbf{2 5}$ (less polar), $\mathrm{CDCl}_{3}$

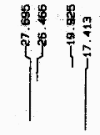

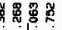

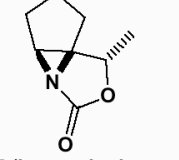

负是

窝

के 


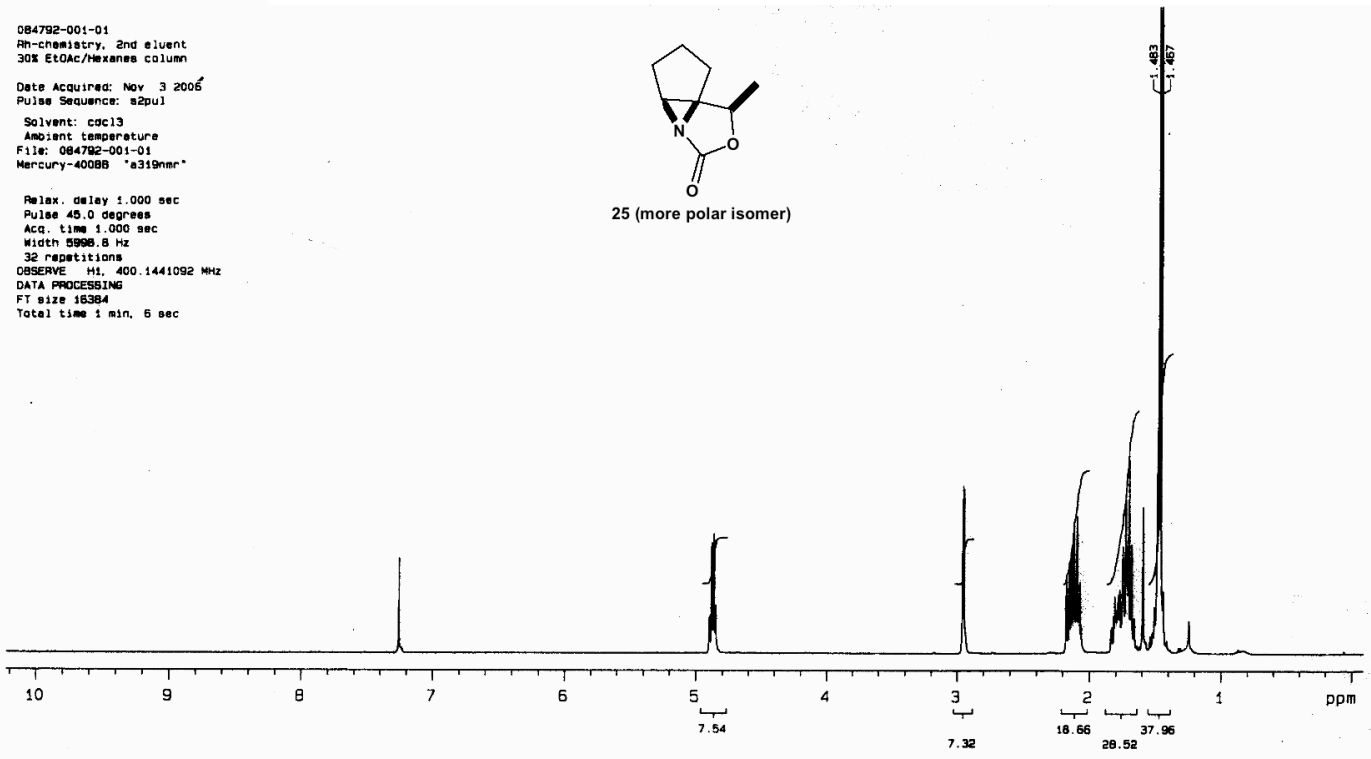

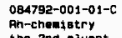

and eliuent. 30kE toac/nexanes"

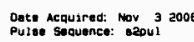

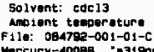

Pulat 45.0 degraes
Acq. tine $1.000 \mathrm{sec}$
Width $250000.0 \mathrm{~Hz}$

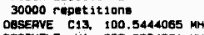

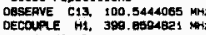

cantinuous ly on

Datr percassiks

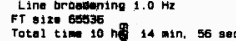

Totel t1m 10 ng 14 min, 56 sec

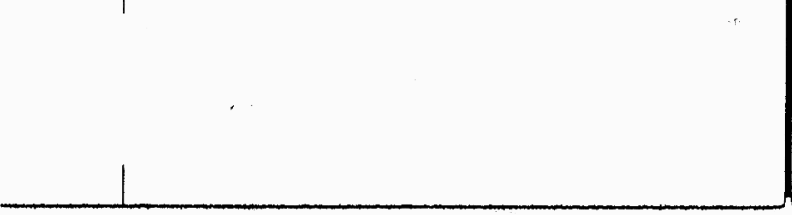

TT

180

160

25 (more polar isomer)

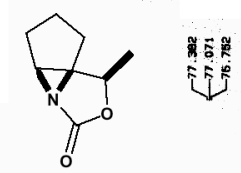

중웅

สู้
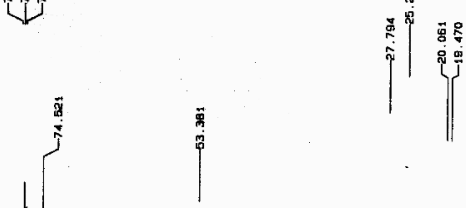

ppm

${ }^{1} \mathrm{H}$ and ${ }^{13} \mathrm{C}$ NMR spectra of 25 (more polar), $\mathrm{CDCl}_{3}$ 


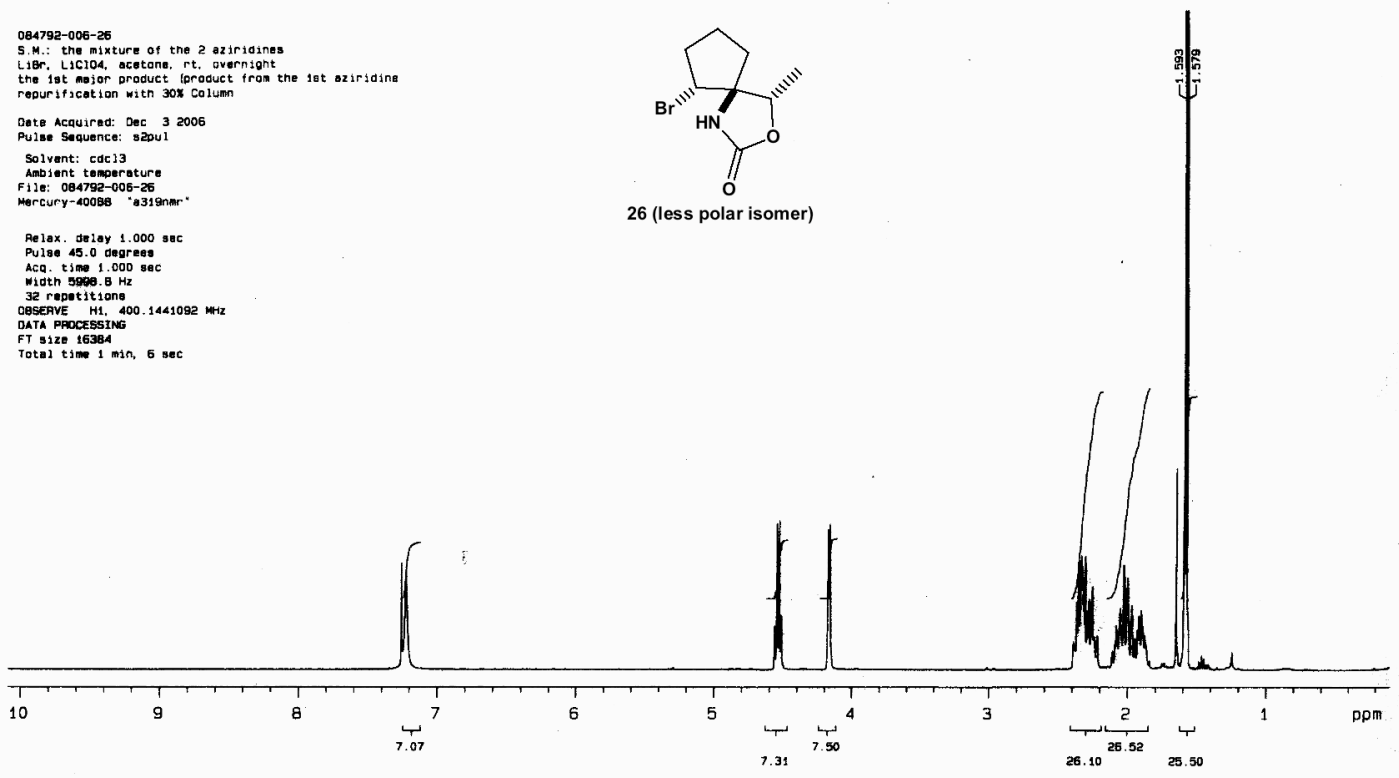

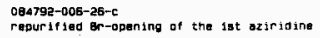

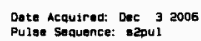

Solvent: Edc 13

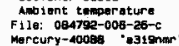

Pulse 45.0 degraes

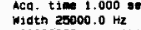

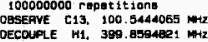

Pomor 40 di
continuous on on

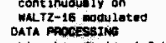

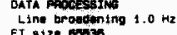

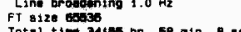

Total time 3 M $138 \mathrm{hr}$. $58 \mathrm{~min}$. B sec
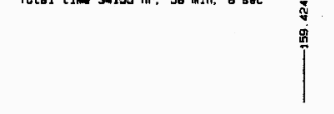

${ }^{1} \mathrm{H}$ and ${ }^{13} \mathrm{C}$ NMR spectra of $\mathbf{2 6}$ (less polar), $\mathrm{CDCl}_{3}$ 

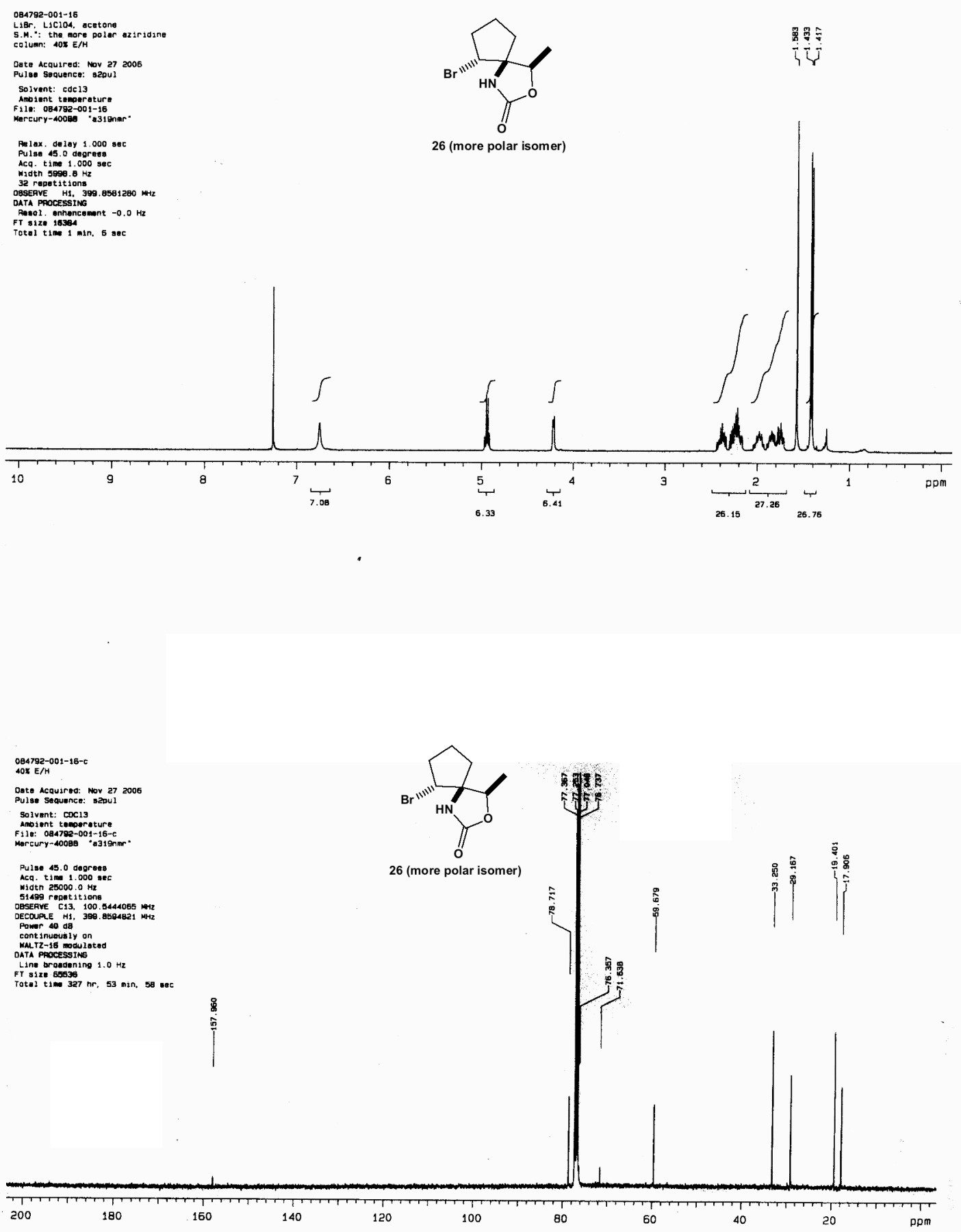

${ }^{1} \mathrm{H}$ and ${ }^{13} \mathrm{C}$ NMR spectra of $\mathbf{2 6}$ (more polar), $\mathrm{CDCl}_{3}$ 
the 1st isomer of -OAc-opnenod aztridine

40\% EtOAc/Bexanes column

Date Acquired: Dec 202006

Pulse Sequence: s2pul

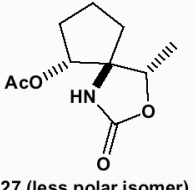

27 (less polar isomer)

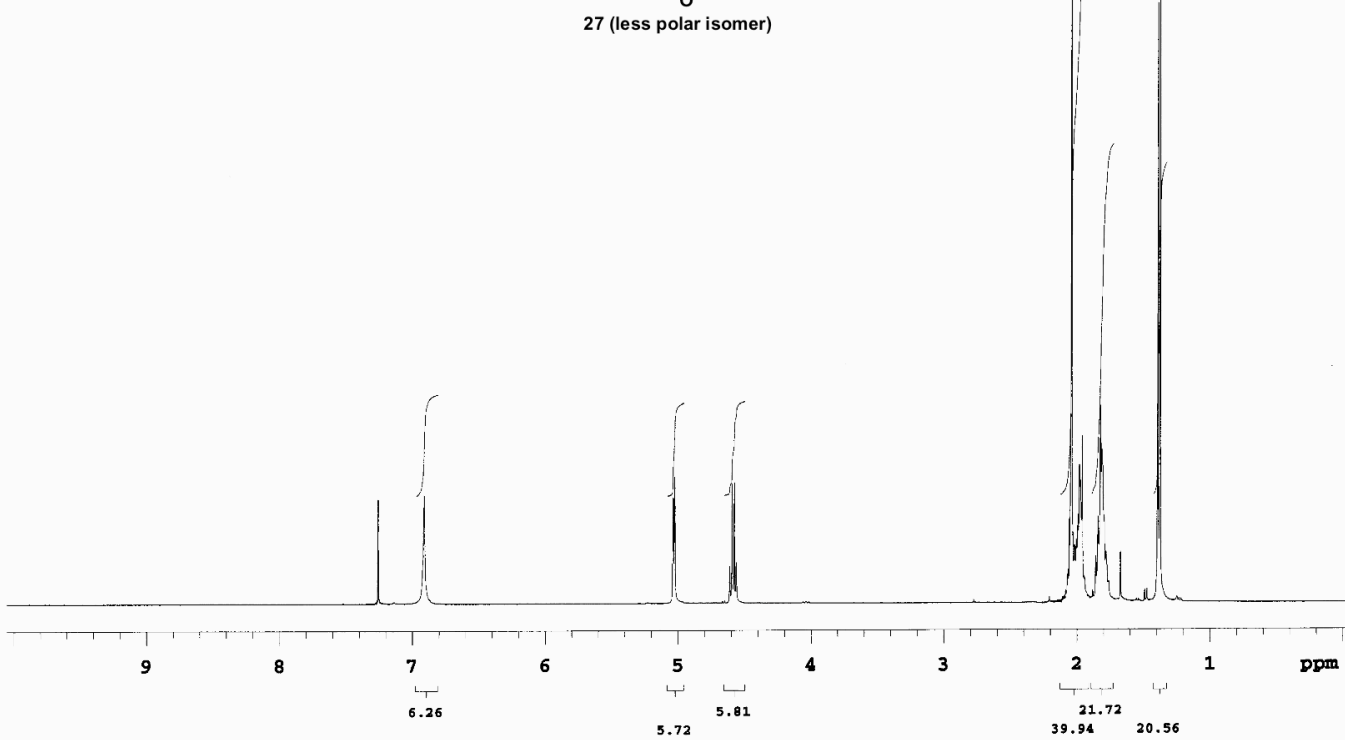

$084792-039-26-c$

the 1.st isomer of -OAC-opened aziridine

40\% EtOAC/Bexanes column

Date Acquired: Dec 202006

pulse sequences 22 put
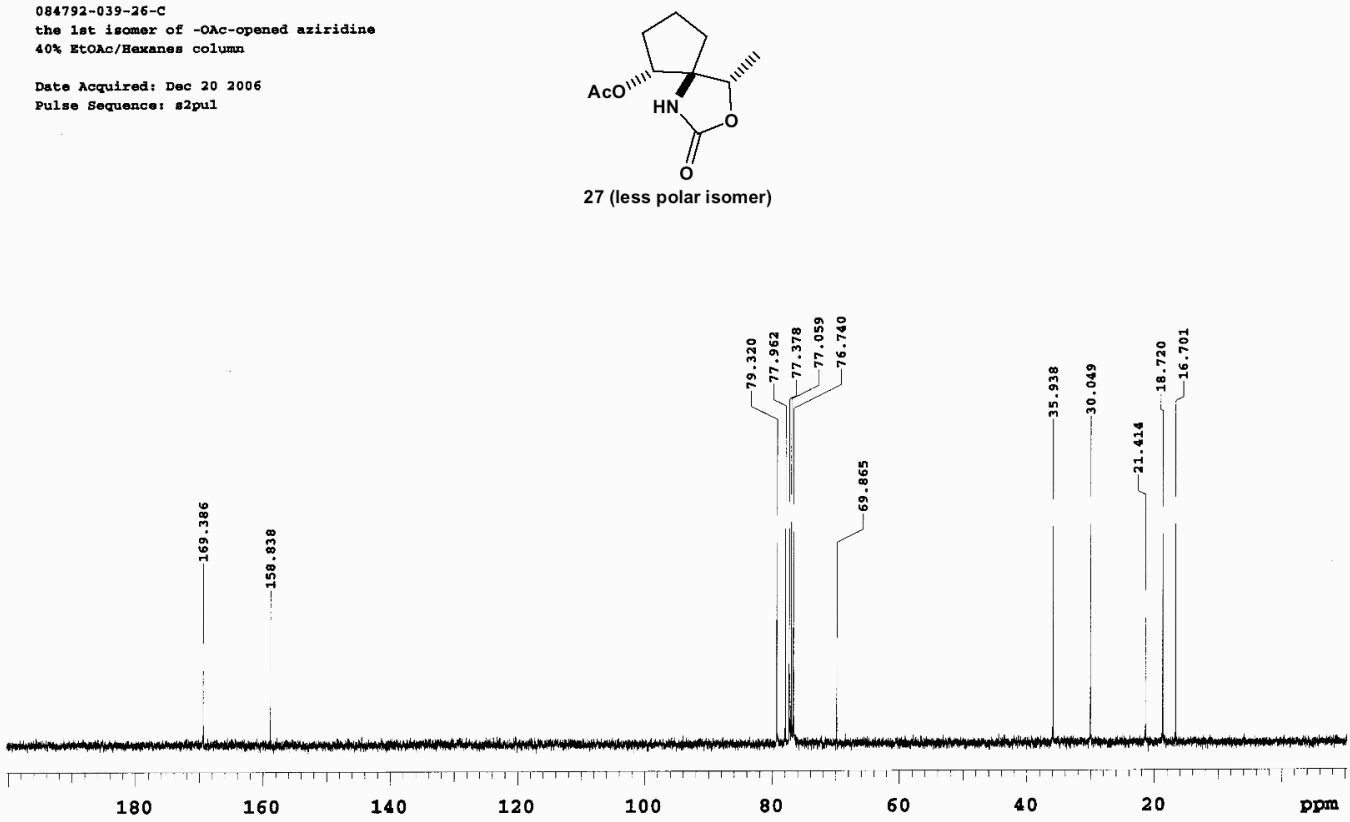

${ }^{1} \mathrm{H}$ and ${ }^{13} \mathrm{C}$ NMR spectra of 27 (less polar), $\mathrm{CDCl}_{3}$ 


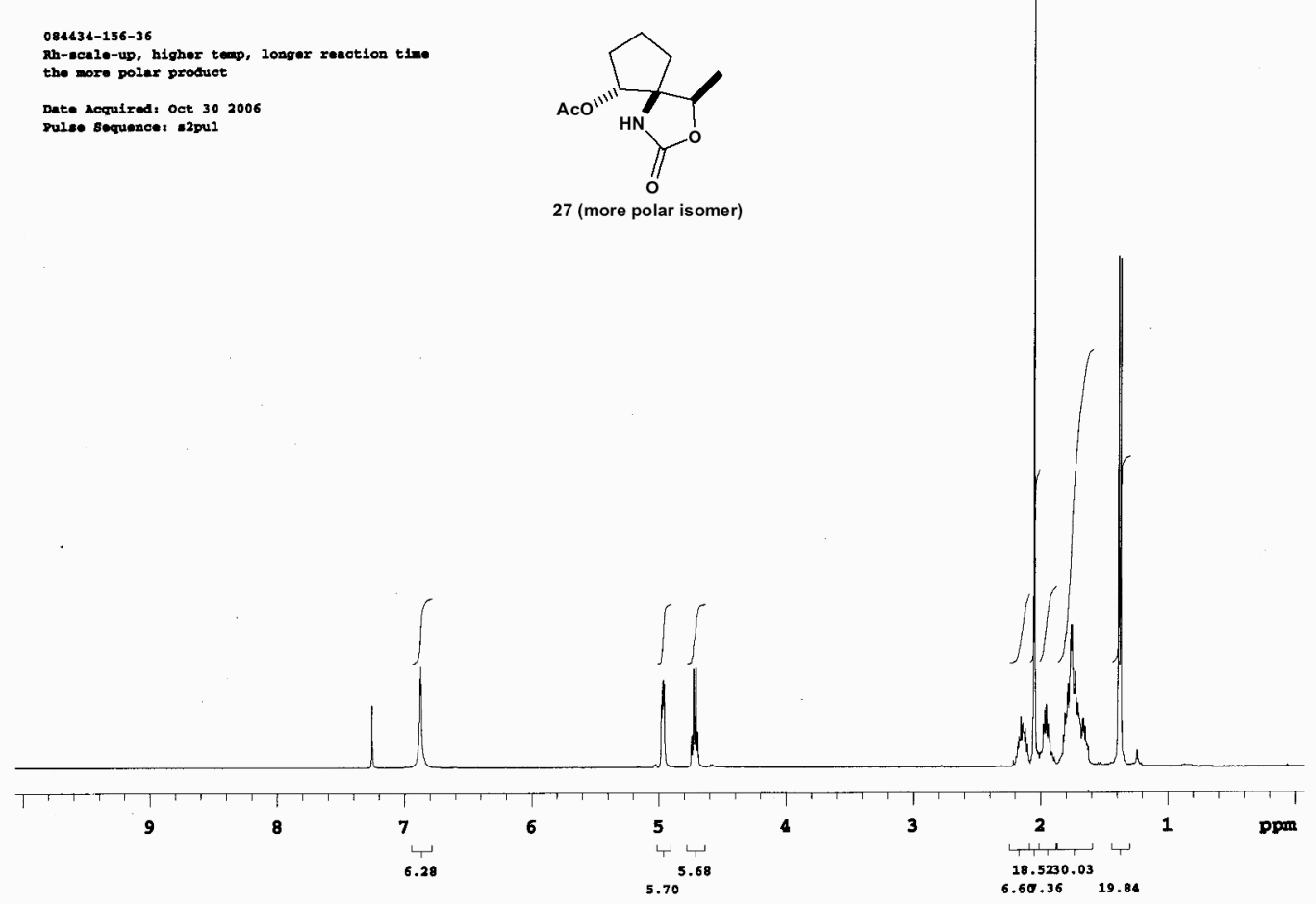

$084434-156-36-C$

ph-scale-up, higher temp, longer reaction time the more polar product

Date Acquired; Oct 302006

Pu1se Sequence: s2pul
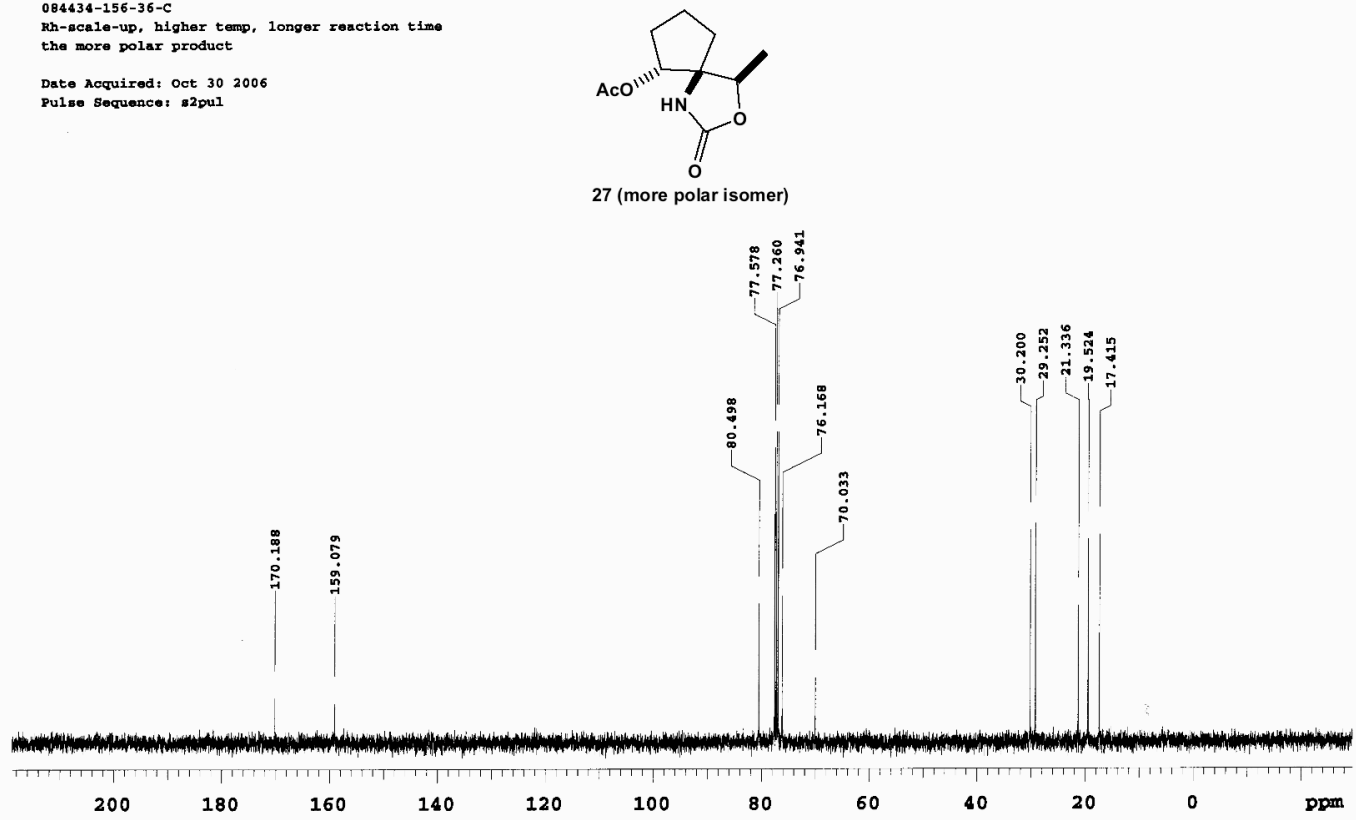

${ }^{1} \mathrm{H}$ and ${ }^{13} \mathrm{C}$ NMR spectra of 27 (more polar), $\mathrm{CDCl}_{3}$ 

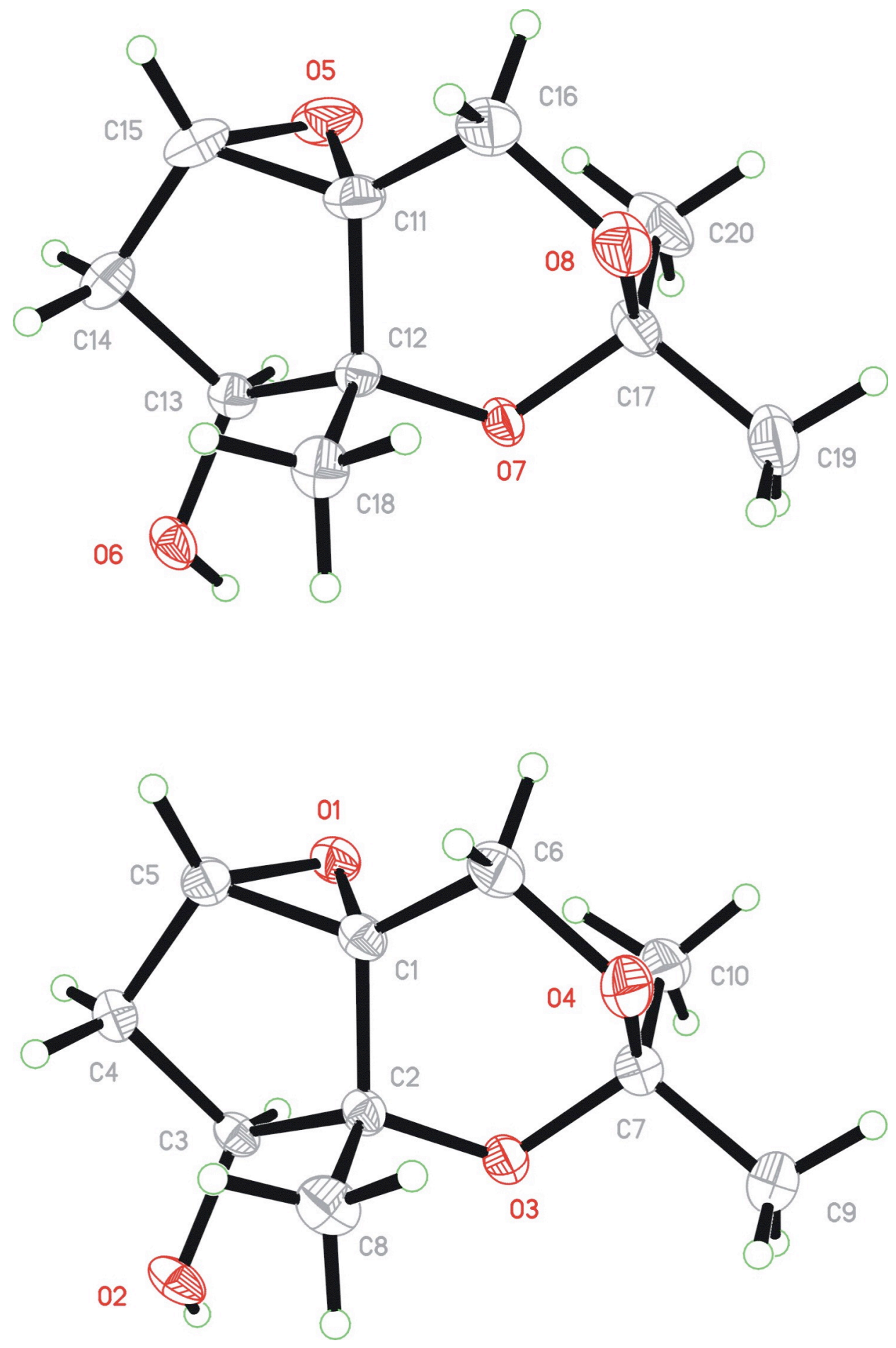

ORTEP view of 12 (two molecules in unit cell) 